JOSÉ MAURO DINIZ OLIVEIRA

ESTUDO DA APLICAÇÃO DE VERMICULITA COMO CARGA ATIVA EM VERNIZ URETÂNICO 
JOSÉ MAURO DINIZ OLIVEIRA

ESTUDO DA APLICAÇÃO DE VERMICULITA COMO CARGA ATIVA EM VERNIZ URETÂNICO

Tese apresentada à Escola Politécnica da Universidade de São Paulo para a obtenção do Título de Doutor em Ciência no Programa de Engenharia Metalúrgica e de Materiais 
JOSÉ MAURO DINIZ OLIVEIRA

\section{ESTUDO DA APLICAÇÃO DE VERMICULITA COMO CARGA ATIVA EM VERNIZ URETÂNICO}

Tese apresentada à Escola Politécnica da Universidade de São Paulo para a obtenção do Título de Doutor em Ciência no Programa de Engenharia Metalúrgica e de Materiais

Área de Concentração: Engenharia Metalúrgica e de Materiais

Orientador: Prof. Dr. Antonio Carlos Vieira Coelho 
Este exemplar foi revisado e corrigido em relação à versão original, sob responsabilidade única do autor e com a anuência de seu orientador.

São Paulo, de Janeiro de 2018.

Assinatura do autor

Assinatura do orientador

Catalogação-na-publicação

Oliveira, José Mauro Diniz

ESTUDO DA APLICAÇÃO DE VERMICULITA COMO CARGA ATIVA EM

VERNIZ URETÂNICO / J. M. D. Oliveira -- versão corr. -- São Paulo, 2018. $105 \mathrm{p}$.

Tese (Doutorado) - Escola Politécnica da Universidade de São Paulo. Departamento de Engenharia Metalúrgica e de Materiais.

1.Vermiculita 2.Verniz 3. Filme de Composição Uretânica I.Universidade de São Paulo. Escola Politécnica. Departamento de Engenharia Metalúrgica e de Materiais II.t. 


\section{AGRADECIMENTOS}

É com satisfação que agradeço à todos que direta ou indiretamente participaram de alguma forma na realização deste trabalho.

Ao meu Orientador, Prof. Dr. Antonio Carlos Vieira Coelho, pela transmissão do conhecimento, pela dedicação e pela imensa paciência disponibilizada durante a realização deste trabalho, por toda contribuição dada a este estudo e, por ter sido um guia seguro nos momentos difíceis pelo qual sou grato pela oportunidade que me foi dada ao me aceitar como seu orientado.

Aos meus filhos Jéssica Abdala Diniz Oliveira e Arthur Abdala Diniz Oliveira e Katia Donizete Abdala, pelo auxílio prestado durante a realização deste trabalho.

Aos meus pais naturais José Diniz Oliveira e Hilda Xavier de Oliveira e aos meus pais adotivos Carolino Pinto da Silva e Geralda Xavier de Oliveira; por tudo.

Ao Prof. André Leone Netto; professor da minha 4⿳亠丷a série, que me encaminhou e inspirou à vida acadêmica.

Agradeço também aos doutores José Ulisses Jansem e Leila Jansen por ter permitido a realização da parte experimental na Empresa "Chem4u Indústria e Comércio de Equipamentos e Produtos Químicos Ltda".

À Profa. Dra Mirta Gladis Mondino pela sua competência no apoio para compreensão dos mecanismos de catalise das reações contidas neste trabalho.

À técnica do LPSS, Valquiria de Fátima Justo, pelo apoio técnico durante o desenvolvimento desta Tese.

À Profa. Fernanda Barberato, pelo apoio dedicado a esta Tese e aos artigos gerados a partir deste trabalho.

Aos colegas e professores da pós-graduação em Engenharia Metalúrgica e de Materiais, pelo convívio, colaboração e aprendizado.

Ao Departamento de Engenharia Metalúrgica e de Materiais, pela oportunidade concedida para a realização do curso e deste trabalho. gratidão.

Aos que por uma razão ou outra não foram citados: fica minha eterna 


\section{RESUMO}

O surgimento de um material na área de engenharia torna-se um marco para buscar novas aplicações gerando assim novas tecnologias. Neste estudo utilizou-se a vermiculita expandida e processada como novo material para sistemas uretânicos. A utilização de qualquer novo material, requer conhecimento prévio de seu desempenho em algumas situações técnicas; resultando com isso, desenvolvimentos de tecnologias para o emprego deste material nos segmentos adequados. Na busca para compreender o comportamento da vermiculita em sistemas uretânicos, esta vermiculita foi processada, a partir da sua forma bruta, até obter uma granulometria adequada para adição em meios uretânicos. A adição da vermiculita em vernizes uretânicos, foi no sentido de gerar conhecimentos sobre o comportamento deste material em sistemas formadores de filmes. Neste estudo, foi investigado o aparecimento de cor, o surgimento de tonalidades, a elevação de dureza de filmes uretânicos, a investigação de ação reacional em sistemas uretânicos de dois componentes e, foi também investigado o efeito de barreira em filmes uretânicos contendo vermiculita processada na sua composição. E, após avaliação dos resultados obtidos, comprovou-se que a vermiculita piroexpandida processada por moagem pode ser utilizada como matéria-prima de interesse em vernizes de composição uretânica.

Palavras-Chave - Vermiculita, Verniz, Filme de Composição Uretânica. 


\section{ABSTRACT}

The discovery of a material in the area of engineering is a milestone to seek new applications thus generating new technologies. In this study the expanded vermiculite was processed as a new material for urethane systems. To use any new material it is necessary to know its performance in some technical situations; to gets developments in technologies for the new use of this material in the appropriate segments. In the search to visualize the behavior of the vermiculite in urethane systems, this vermiculite was processed, from its crude form, until obtaining suitable granulometry for addition in urethane media. The addition of vermiculite to urethane varnishes was aimed at generating knowledge about the behavior of this material in film forming systems. In this study, the development ocolor, the appearance of shades, urethane film hardness increase, reactional action investigation in two component urethane systems were investigated and the barrier effect was also investigated in urethane films containing vermiculite processed in Its composition. After evaluation of the obtained results, it was verified that the vermiculite pyroexpandida processed by grinding can be used as raw material of interest in varnishes of urethane composition.

Keywords - Vermiculite, Varnish, Urethane Composition Film. 


\section{LISTA DE FIGURAS}

Figura 1 - Representação esquemática da reação entre os grupos $-\mathrm{N}=\mathrm{C}=\mathrm{O}$ e $-\mathrm{OH}$ (ISMAIL et al., 2016)

Figura 2 - Esquema de uma aplicação automotiva.

Figura 3 - Reações de grupos NCO com grupos OH (Fonte: Collong et al., 2002) ..11

Figura 4- Representação esquemática dos processamentos de moagem envolvendo a vermiculita expandida em meios butilglicol e água.Erro! Indicador não definido.8

Figura 5- Representação esquemática dos processamentos de moagem envolvendo a vermiculita expandida em solvente orgânico acetato de butilglicol... Erro! Indicador não definido.

Figura 6 - Equipamento Robot Semi Tech Durr Modelo ECO Bell 2 Serrilhado utilizado para aplicação das tintas e do verniz sobre as chapas de cor preta e prata. (Fonte Axalta.Co) .24

Figura 7 - Viscosímetro Copo Ford 4, equipamento utilizado para determinação da viscosidade. Erro! Indicador não definido.8

Figura 8 - Equipamento para determinação de dureza . 299

Figura 9 - Pistola de aplicação tipo "spray. 322

Figura 10 - Curva de difração de raios $X$ da vermiculita de São Luís de Montes Belos, "in natura" (não piroexpandida). 366

Figura 11 - Curva de difração de raios $X$ da vermiculita comercial de São Luís de Montes Belos, piroexpandida. O máximo de escala de intensidade desta curva de DRX é igual à 0,5X do máximo da curva de DRX da Figura 10.

Figura 12 - Curvas de difração de raios $X$ da vermiculita piroexpandida processada por moagem em meio aquoso (a) por $2 \mathrm{~h}$ e (b) por $4 \mathrm{~h}$. O máximo de escala de intensidade de cada uma curvas de DRX é igual à $0,1 \mathrm{X}$ do máximo da curva de DRX da Figura 10. 388

Figura 13 - Curva de difração de raios $X$ da vermiculita piroexpandida após calcinação adicional por $3 \mathrm{~h}$ a $1000^{\circ} \mathrm{C}$. O máximo de escala de intensidade desta curva de $D R X$ é igual à $0,1 X$ do máximo da curva de DRX da Figura 10 (o mesmo máximo de escala da Figura 12). 399

Figura 14 - Imagens de microscopia eletrônica de varredura (MEV) de: (a) uma partícula da vermiculita piroexpandida comercial empregada nesta Tese; (b)-(c) detalhes com maior ampliação de outras partículas examinadas na mesa preparação 
Figura 15 - Imagens de MEV de agregados de partículas obtidas a partir do processamento por moagem de vermiculita piroexpandida por $2 \mathrm{~h}$ em água desmineralizada: (a) imagem em campo geral, com pequeno aumento, para mostrar o aspecto geral do pó obtido após secagem e (b) agregado de partículas. Fonte: PMT-EPUSP

Figura 16 - Imagens de MEV de agregados de partículas obtidas a partir do processamento por moagem de vermiculita piroexpandida por $4 \mathrm{~h}$ em água desmineralizada: (a) imagem em campo geral, com pequeno aumento, para mostrar o aspecto geral do pó obtido após secagem e (b) detalhe de agregado de partículas. Fonte: PMT-EPUSP

Figura 17 - Imagens de MEV de agregados de partículas obtidas a partir do processamento por moagem de vermiculita piroexpandida por $8 \mathrm{~h}$ em butilglicol: (a) imagem em campo geral, com pequeno aumento, para mostrar o aspecto geral do pó obtido após secagem e (b) detalhe de agregado de partículas. Fonte: IF-USP..............................................44

Figura 18 - Imagens de MEV de agregados de partículas obtidas a partir do processamento por moagem de vermiculita piroexpandida por $12 \mathrm{~h}$ em butilglicol: (a) imagem em campo geral, com pequeno aumento, para mostrar o aspecto geral do pó obtido após secagem e (b) detalhe de agregado de partículas. Fonte: IF-USP.

Figura 19 - (a) vermiculita piroexpandida comercial, antes do processamento de moagem; (b) Dispersão de vermiculita após processamento de moagem $(676 \mathrm{~nm})$;(c) pó de vermiculita $(676 \mathrm{~nm})$ seco e desagregado, obtido após processamento de moagem. 46

Figura 20 - Aplicador tipo quadrangular, placa de vidro plana e amostra de vermiculita processada em meio aquoso. 49

Figura 21 - Placas de vidro aplicadas com dispersão de vermiculita processada: (a) vermiculita com 195,5 nm e (b) vermiculita com 170,9 nm.

Figura 22 - Curvas da refletância para partículas de vermiculita processada, com tamanhos médios de 170,9 nm e 195,5 nm.

Figura 23 - Representação esquemática do significado das variáveis $a^{*}, b^{*}$ e $L$ de acordo com o sistema recomendado pela Commission Internationale de L'Eclairage (International Commission on Illumination - CIE). 52

Figura 24 - Aspecto visual dos sistemas contendo resina e vermiculita em pó: (a) resina uretênica pura; (b) partículas secas de vermiculita, (626 nm); (c) filme obtido a partir da dispersão em resina uretânica com partículas de vermiculita processada, $(626 \mathrm{~nm})$. .53

Figura 25 - Refletância observada nas avaliações dos corpos de prova contendo vermiculita processada $626 \mathrm{~nm}$ com resina uretânica: (a) VP245-C; (b) VP245-D; (c) VP245-E. 
Figura 26 - Refletância observada nas avaliações dos corpos de prova contendo vermiculita processada $479 \mathrm{~nm}$ com resina uretânica: (a) VP246-C; (b) VP246-D; (c) VP246-E.

Figura 27 - Variação de $\Delta a^{*}$ e $\Delta b^{*}$ com as relações [massa de vermiculita] / [massa de resina] (em $\mathrm{g} / \mathrm{g})$ para asduas séries de amostras estudadas nesta Tese: VP245 (tamanho médio de partículas $=626 \mathrm{~nm}$ ) e VP246 (tamanho médio de partículas $=479 \mathrm{~nm}$ ). .58

Figura 28 - Variação de $\Delta \mathrm{E}^{*}$ (eixo vertical à esquerda) e $\Delta \mathrm{L}^{*}$ (eixo vertical à direita) com as relações [massa de vermiculita] / [massa de resina] (em g/g) para as duas séries de amostras estudadas nesta Tese: VP245 (tamanho médio de partículas $=626 \mathrm{~nm}$ ) e VP246 (tamanho médio de partícula= $479 \mathrm{~nm})$.

Figura 29 - Representação esquemática do processo de preparação das aplicações sobre tintas preta e prata.

Figura 30 - Chapas pintadas com verniz contendo partículas de vermiculita processada sobre as cores prata e preto.

Figura 31 - Esquema representativo das camadas de tinta e verniz aplicados em cada chapa avaliada neste estudo.

Figura 32 - Variação dos valores de $\Delta \mathrm{L}^{*}, \Delta \mathrm{a}^{*}$ e $\Delta \mathrm{b}^{*}$ em relação à quantidade de vermiculita processada para placas pintadas com tinta prata - leituras efetuadas no ângulo de $45^{\circ}$ de reflexão da luz. $8 \mathrm{~h}$ e $12 \mathrm{~h}$ : tempos de moagem da vermiculita processada, correspondendo respectivamente a tamanhos médios de partícula de 195,5 nm e 170,9 nm Fonte : o Autor

Figura 33 - Variação dos valores de $\Delta \mathrm{L}^{*}, \Delta \mathrm{a}^{*} \mathrm{e} \Delta \mathrm{b}^{*}$ em relação à quantidade de vermiculita processada para placas pintadas com tinta prata - leituras efetuadas no ângulo de $75^{\circ}$ de reflexão da luz. $8 \mathrm{~h}$ e $12 \mathrm{~h}$ : tempos de moagem da vermiculita processada, correspondendo respectivamente a tamanhos médios de partícula de 195,5 nm e 170,9 nm 65

Figura 34 - Variação dos valores de $\Delta L^{*}, \Delta a^{*}$ e $\Delta b^{*}$ em relação à quantidade de vermiculita processada para placas pintadas com tinta prata - leituras efetuadas nos ângulos de $45^{\circ}$ e $75^{\circ}$ de reflexão da luz. 8h: tempo de moagem da vermiculita processada, correspondendo a tamanho médio de partícula de $195,5 \mathrm{~nm}$ 66

Figura 35 - Variação dos valores de $\Delta \mathrm{L}^{*}, \Delta \mathrm{a}^{*}$ e $\Delta \mathrm{b}^{*}$ em relação à quantidade de vermiculita processada para placas pintadas com tinta PRATA - leituras efetuadas nos ângulos de $45^{\circ}$ e $75^{\circ}$ de reflexão da luz. $12 \mathrm{~h}$ : tempo de moagem da vermiculita processada, correspondendo a tamanho médio de partícula de 170,9 nm 66

Figura 36 - Variação dos valores de $\Delta \mathrm{L}^{*}, \Delta \mathrm{a}^{*} \mathrm{e} \Delta \mathrm{b}^{*}$ em relação à quantidade de vermiculita processada para placas pintadas com tinta preta - leituras efetuadas no ângulo de $45^{\circ}$ de reflexão da luz. $8 \mathrm{~h}$ e $12 \mathrm{~h}$ : tempos de 
moagem da vermiculita processada, correspondend o respectivamente a tamanhos médios de partícula de 195,5 nm e 170,9 nm.

Figura 37 - Variação dos valores de $\Delta \mathrm{L}^{*}, \Delta \mathrm{a}^{*} \mathrm{e} \Delta \mathrm{b}^{*}$ em relação à quantidade de vermiculita processada para placas pintadas com tinta preta - leituras efetuadas no ângulo de $75^{\circ}$ de reflexão da luz. $8 \mathrm{~h}$ e $12 \mathrm{~h}$ : tempos de moagem da vermiculita processada, correspondendo respectivamente a tamanhos médios de partícula de 195,5 nm e 170,9 nm. .68

Figura 38 - Variação dos valores de $\Delta \mathrm{L}^{*}, \Delta \mathrm{a}^{*} \mathrm{e} \Delta \mathrm{b}^{*}$ em relação à quantidade de vermiculita processada para placas pintadas com tinta preta - leituras efetuadas nos ângulos de $45^{\circ}$ e $75^{\circ}$ de reflexão da luz. 8h: tempo de moagem da vermiculita processada, correspondendo a tamanho médio de partícula de $195,5 \mathrm{~nm}$. 69

Figura 39 - Variação dos valores de $\Delta \mathrm{L}^{*}, \Delta \mathrm{a}^{*} \mathrm{e} \Delta \mathrm{b}^{*}$ em relação à quantidade de vermiculita processada para placas pintadas com tinta preta - leituras efetuadas nos ângulos de $45^{\circ}$ e $75^{\circ}$ de reflexão da luz. $12 \mathrm{~h}$ : tempo de moagem da vermiculita processada, correspondendo a tamanho médio de partícula de $170,9 \mathrm{~nm}$.

Figura 40 - Evolução da dureza König com o tempo de envelhecimento para filmes produzidos com adição de vermiculita processada com diâmetro médio de partícula igual a 195,5 nm, em comparação com a evolução da dureza do filme sem adição de vermiculita (branco) .72

Figura 41 - Evolução da dureza König com o tempo de envelhecimento para filmes produzidos com adição de vermiculita processada com diâmetro médio de partícula igual a 170,9 nm, em comparação com a evolução da dureza do filme sem adição de vermiculita (branco)

Figura 42 - Evolução da dureza König com o tempo de envelhecimento para filmes produzidos com adição de $0,87 \%$ de vermiculita processada com diâmetros médios de partículas iguais a $170,9 \mathrm{~nm}$ e $195,5 \mathrm{~nm}$, em comparação com a evolução da dureza do filme sem adição de vermiculita (branco).

Figura 43 - Evolução da dureza König com o tempo de envelhecimento para filmes produzidos com adição de $1,74 \%$ de vermiculita processada com diâmetros médios de partícula iguais a $170,9 \mathrm{~nm}$ e $195,5 \mathrm{~nm}$, em comparação com a evolução da dureza do filme sem adição de vermiculita (branco).

Figura 44 - Evolução da dureza König com o tempo de envelhecimento para filmes produzidos com adição de $3,48 \%$ de vermiculita processada com diâmetros médios de partículas iguais a $170,9 \mathrm{~nm}$ e $195,5 \mathrm{~nm}$, em comparação com a evolução da dureza do filme sem adição de

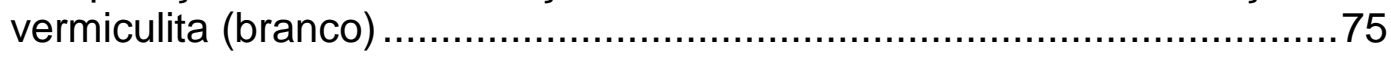

Figura 45 - Evolução da viscosidade determinada pelo método Copo Ford 4 com o tempo de reação para os sistemas contendo vermiculita processada de 
tamanho médio de partículas de $195,5 \mathrm{~nm}$, sem calcinação a $1000^{\circ} \mathrm{C}$ (amostras PVi-SM, linha pontilhada) e após calcinação a $1000{ }^{\circ} \mathrm{C}$ (amostra PVi-CM, linha tracejada).... .78

Figura 46 - Evolução da viscosidade determinada pelo método Copo Ford 4 com a concentração de vermiculita (dada em g de vermiculita / $120 \mathrm{~g}$ de (verniz + endurecedor) para sistemas contendo vermiculita processada de tamanho médio de partículas de $195,5 \mathrm{~nm}$, sem calcinação a $1000^{\circ} \mathrm{C}$, para diferentes tempos de reação.

Figura 47 - Evolução da viscosidade determinada pelo método Copo Ford 4 com a concentração de vermiculita (dada em g de vermiculita / $120 \mathrm{~g}$ de (verniz + endurecedor) para sistemas contendo vermiculita processada de tamanho médio de partículas de $195,5 \mathrm{~nm}$, após calcinação a $1000^{\circ} \mathrm{C}$, para diferentes tempos de reação. .80

Figura 48 - Evolução da viscosidade determinada pelo método Copo Ford 4 com o tempo de reação para os sistemas contendo vermiculita processada de tamanho médio de partículas de $170,9 \mathrm{~nm}$, sem calcinação a $1000^{\circ} \mathrm{C}$ (amostras PVi-SM, linha pontilhada) e após calcinação a $1000^{\circ} \mathrm{C}$ (amostra PVi-CM, linha tracejada)....

Figura 49 - Evolução da viscosidade determinada pelo método Copo Ford 4 com a concentração de vermiculita (dada em g de vermiculita / $120 \mathrm{~g}$ de (verniz + endurecedor) para sistemas contendo vermiculita processada de tamanho médio de partículas de $170,9 \mathrm{~nm}$, sem calcinação a $100^{\circ} \mathrm{C}$, para diferentes tempos de reação. Todas as amostras com $7 \mathrm{~h}$ de reação gelificaram, e não foi possível medir a viscosidade

Figura 50 - Evolução da viscosidade determinada pelo método Copo Ford 4 com a concentração de vermiculita (dada em g de vermiculita / $120 \mathrm{~g}$ de (verniz + endurecedor) para sistemas contendo vermiculita processada de tamanho médio de partículas de $170,9 \mathrm{~nm}$, com calcinação a $1000^{\circ} \mathrm{C}$, para diferentes tempos de reação. Todas as amostras com tempos de reação iguais ou superiores a 5 h gelificaram, e não foi possível medir a viscosidade. .83

Figura 51 - Diagrama de impedância de Nyquist, solução de $\mathrm{NaCl} 0,1 \mathrm{M}$, para liga de aço carbono 1020 Metal Base (MB) e liga aço carbono 1020 tratado com fosfato de zinco revestidos com dispersão uretânica contendo vermiculita processada (VE). 


\section{LISTA DE TABELAS}

Tabela 1 - Principais reservas minerais de alguns minerais industriais do Brasil e sua participação mundial - 2014. Fonte: Adaptada do Sumário Mineral 2015 Departamento Nacional de Produção Mineral (DNPM) - Ministério de Minas e Energia ..........................................................................

Tabela 2 - Análises químicas (retiradas da literatura) de vermiculitas comerciais, de ocorrências brasileiras e internacionais.

Tabela 3 - Relação em massa para os corpos de prova contendo dispersão uretânica e vermiculita processada em meio aquoso $(626 \mathrm{~nm})$.

Tabela 4 - Relação em massa para os corpos de prova contendo dispersão uretânica e vermiculita processada em meio aquoso $(479 \mathrm{~nm})$. 21

Tabela 5 - Preparo do verniz para aplicação sobre tinta prata 23

Tabela 6 - Preparo do verniz para aplicação sobre tinta preta. 23

Tabela 7 - Massas (g) utilizadas para o preparo das amostras para ensaio de aceleração reacional da vermiculita processada sem tratamento térmico a $1000^{\circ} \mathrm{C}$ em mufla e moída em acetato de butilglicol (195,5 nm).

Tabela 8 - Massas (g) utilizadas para o preparo das amostras para ensaio de aceleração reacional da vermiculita processada sem tratamento térmico a $1000^{\circ} \mathrm{C}$ em mufla e moída em acetato de butilglicol (170,9 nm). .26

Tabela 9 - Massas (g) utilizadas para o preparo das amostras para ensaio de aceleração reacional da vermiculita processada com tratamento térmico em mufla a $1000^{\circ} \mathrm{C}$ e moída em acetato de butilglicol (195,5 nm).

Tabela 10 - Massas $(\mathrm{g})$ utilizadas para o preparo das amostras para ensaio de aceleração reacional da vermiculita processada com tratamento térmico em mufla e moída em acetato de butilglicol $(170,9 \mathrm{~nm})$.

Tabela 11 - Preparo das amostras para análise das propriedades eletroquímicas dos filmes aplicados sobre chapa de aço carbono 1020 com fosfato de zinco.

Tabela 12 - Análise Química por fluorescência de raios $X$ da vermiculita piro expandida que foi a base dos materiais produzidos nesta Tese.

Tabela 13 - Médias dos tamanhos, em nanômetros, das partículas de vermiculita obtidas após processamento em moinho.

Tabela 14 - Resultado da Picnometria de Hélio - Densidade $\left(\mathrm{g} / \mathrm{cm}^{3}\right)$ dos pós de vermiculita piro expandida moída por $2 \mathrm{~h}$ e $4 \mathrm{~h}$ em água desmineralizada. 
Tabela 15 - Dados colorimétricos obtidos nas avaliações dos corpos de prova contendo vermiculita processada $626 \mathrm{~nm}$ com resina uretânica.

Tabela 16 - Variações colorimétricas dos corpos de prova contendo vermiculita processada $626 \mathrm{~nm}$ em relação à vermiculita processada sem resina. ...55

Tabela 17 - Dados colorimétricos obtidos nas avaliações dos corpos de prova contendo vermiculita processada $479 \mathrm{~nm}$ com resina uretânica.

Tabela 18 - Variações colorimétricas dos corpos de prova contendo vermiculita processada $479 \mathrm{~nm}$ em relação à vermiculita processada sem resina. ...56

Tabela 19 - Resultados das leituras de cor dos painéis pintados com tinta prata nos ângulos de leitura de $45^{\circ}$ e $75^{\circ}$.

Tabela 20 - Resultados das leituras de cor dos painéis pintados com tinta preta nos ângulos de leitura de $45^{\circ}$ e $75^{\circ}$.

Tabela 21 - Resultados da dureza do verniz determinada pelo pêndulo König (norma ASTM D 4366-94)

Tabela 22 - Viscosidades obtidas no Copo Ford 4 a 25ํ $\mathrm{C}$ para sistemas contendo vermiculita processada (tamanhos médios de partícula iguais a 195,5 e $170,9 \mathrm{~nm}$ ) sem calcinação a $1000^{\circ} \mathrm{C}$

Tabela 23 - Viscosidades obtidas no Copo Ford 4 a 25ํ para sistemas contendo vermiculita processada (diâmetros médios de partícula iguais a 195,5 e $170,9 \mathrm{~nm}$ ) com calcinação a $1000^{\circ} \mathrm{C}$

Tabela 24 - Sugestões para futuros trabalhos 92 


\section{SUMÁRIO}

1. INTRODUÇÃO

2. OBJETIVO

3. REVISÃO DA LITERATURA 4

3.1 Vermiculita 4

3.1.1 Informações Sobre Vermiculita 4

3.2 Sistemas Uretânicos 8

3.2.1 Informações Gerais Sobre Sistemas Uretânicos 8

3.2.1.1 Vernizes Uretânicos 9

4. MATERIAIS E MÉTODOS. 12

$\begin{array}{lll}4.1 & \text { Materiais } & 12\end{array}$

$\begin{array}{lll}4.2 & \text { Métodos } & 13\end{array}$

4.2.1 Caracterização da vermiculita 13

4.2.1.1 Análise química por fluorescência de raios $X$

$\begin{array}{ll}\text { 4.2.1.2 Difração de raios } X & 13\end{array}$

4.2.1.3 Análise da morfologia das partículas por microscopia 14 eletrônica de varredura (MEV)

4.2.1.4 Determinação do tamanho de partícula por espalhamento de 14 luz 
4.2.1.6 Análise de cor

4.2.2 Processo de moagem para a vermiculita expandida.

4.2.2.1 Preparo das bases de moagem

4.2.3 Preparação para verificação de cor das partículas de vermiculita processada: somente partículas puras e partículas com resina uretânica

4.2.4 Preparação dos vernizes para aplicação sobre tintas de cores preta e prata.

4.2.6 Preparação dos vernizes para investigação de aceleração 25 reacional 
5.2.4 Determinação de tamanho de partículas por espalhamento de LUZ- LASER

5.2.5 Determinação da massa específica por picnometria de hélio

5.3 - Surgimento de cor em verniz uretânico após adição de partículas de vermiculita processada

5.3.1 Resultados da avaliação do surgimento de cor e sua interpretação

5.3.2 Estudo da cor em vernizes automotivos aplicados sobre tintas de cores preta e prata

5.4 Desenvolvimento de dureza superficial nos filmes de vernizes contendo vermiculita processada

5.5 Estudo do efeito da adição de vermiculita processada na aceleração da reação em sistemas uretânico de dois componentes

5.6 Comportamento da vermiculita processada como barreira ao transporte de massa em filmes uretânicos

6. CONCLUSÕES 


\section{INTRODUÇÃO}

Uma das áreas notáveis, quando se fala em tecnologia dos materiais, é o trabalho de pesquisa e desenvolvimento visando buscar novas aplicações tecnológicas, especificamente, quando o desenvolvimento apresenta uma inovação sobre materiais tradicionais.

O surgimento de uma nova matéria-prima resulta em descrever um conjunto de propriedades para orientar futuras aplicações tecnológicas, gerando possibilidades comerciais.

O século $X X$ foi promissor para uma nova classe de materiais: os compósitos. $A$ evolução destes materiais multifásicos foi contínua no período de mais de um século, fornecendo oportunidades para obtenção de diversos materiais combinados. Já compósitos com matriz polimérica são bastante utilizados em diversas aplicações devido à facilidade de trabalho a temperatura ambiente e aos baixos custos quando comparados a outros compósitos de matrizes cerâmicas ou metálicas (CALLISTER, 2007).

Embora a vermiculita seja um mineral comumente utilizado nos segmentos agrícolas e de embalagens, a sua forma processada, possuindo tamanho muito reduzido como no presente estudo, pode alcançar outras aplicações no mercado, como por exemplo o emprego em compósitos de matriz polimérica.

As partículas, obtidas pelo processamento da vermiculita expandida, apresentam características dimensionais e de coloração típicas das partículas dos pigmentos e ou das cargas utilizadas no campo e tintas (FAZENDA et al., 2009) e das partículas utilizadas em estudo de compósitos (GIBSON, 1989).

A divulgação do método de obtenção desta nova forma da matéria-prima a partir da vermiculita expandida bruta, a descrição das técnicas iniciais para sua inserção em vernizes, e a descrição das propriedades resultantes desta combinação com resinas uretânicas, pode abrir caminhos para novas tecnologias no campo de materiais compósitos de matriz polimérica ou de outras matrizes. 
Neste trabalho, os tamanhos das partículas de vermiculita são controlados. Além disso, os produtos compósitos obtidos com essas partículas não devem prejudicar o aspecto visual do sistema especificamente dos filmes uretânicos.

O tamanho das partículas adicionadas aos vernizes uretânicos é fator limitante para obtenção de aspecto satisfatório. Comumente nos vernizes tradicionais de mercado, por exemplo nos vernizes automotivos, não é costume a utilização de materiais promotores de cor em sua composição.

Este trabalho experimental, propõe então, a utilização de vermiculita processada como matéria-prima para venizes uretânicos. Esta utilização confere propriedades interessantes aos vernizes uretânicos mono e bi-componentes estudados nesta Tese. 


\section{OBJETIVO}

Esta Tese tem como objetivos:

- obter um material particulado, nano ou micrométrico, a partir de vermiculita piroexpandida comercial (que será chamada de "vermiculita processada" ao longo da Tese);

- estudar a utilização dessa vermiculita processada como carga ativa em verniz uretânico.

Neste trabalho adotou-se um conceito atípico às características dos vernizes do mercado automotivo, ou seja, a adição de partículas coloridas a um verniz incolor. Essa adição se fez necessária para compreender as propriedades geradas pelas partículas de vermiculita em um sistema formador de filme orgânico, no caso, o sistema dos vernizes uretânicos. 


\section{REVISÃO DE LITERATURA}

Esta revisão da literatura não encontrou referências para utilização de partículas de vermiculita processada em filmes de vernizes.

A seguir, nessa revisão, serão apresentadas informações de maior relevância para fundamentação do uso da vermiculita no desenvolvimento experimental desta Tese sobre a utilização da vermiculita como carga ativa em verniz uretânico.

\subsection{Vermiculita}

\subsubsection{Informações sobre vermiculita}

Segundo dados divulgados no Sumário Nacional de Produção Mineral de 2015, publicado pelo Ministério de Minas e Energia - MME, (LIMA, 2015), o Brasil possui cerca de $10 \%$ das reservas mundiais de vermiculita, e a reserva lavrável é estimada em torno de 6,3 milhões de toneladas (Tabela 1). Esta publicação também divulga que a produção de vermiculita beneficiada foi 56.444 toneladas em 2014, e que os principais campos de destinação deste mineral no Brasil são a construção civil, a agricultura e a indústria química.

Tabela 1 - Principais reservas minerais de alguns minerais industriais do Brasil e sua participação mundial -2014 .

\begin{tabular}{|c|c|c|c|}
\hline Substância & $\begin{array}{c}\text { Un. t } \\
\text { (tonelada) }\end{array}$ & Brasil & $\begin{array}{c}(\%) \\
\text { Mundo }\end{array}$ \\
\hline Bentonita & $10^{3} \mathrm{t}$ & 34.916 & Não divulgado \\
\hline Caulim & $10^{6} \mathrm{t}$ & 7.056 & Não divulgado \\
\hline Crisotila & $10^{3} \mathrm{t}$ & 9.804 & Não divulgado \\
\hline Diatomita & $10^{3} \mathrm{t}$ & 1.938 & 0,1 \\
\hline Felspato & $10^{\circ} \mathrm{t}$ & 316 & Não divulgado \\
\hline Gipsita & $10^{3} \mathrm{t}$ & 400.000 & Não divulgado \\
\hline Talco e Pirofilita & $10^{3} \mathrm{t}$ & 52.133 & 13,8 \\
\hline Vermiculita & $10^{3} \mathrm{t}$ & 6.287 & 10,1 \\
\hline
\end{tabular}

Fonte: Adaptada do Sumário Mineral 2015 - Departamento Nacional de Produção Mineral (DNPM) Ministério de Minas e Energia

A vermiculita é um filossilicato 2:1 hidratado com fórmula química definida pela "International Mineralogical Association" como sendo a seguinte: 


$$
[\mathrm{Mg}]_{0,35}\left(\mathrm{Mg}, \mathrm{Fe}^{3+}, \mathrm{Al}\right)_{3}(\mathrm{Si}, \mathrm{Al})_{4} \mathrm{O}_{10} \cdot 4 \mathrm{H}_{2} \mathrm{O}(\mathrm{IMA}, 2016) .
$$

Sua estrutura pode ser derivada da estrutura do talco, com substituições tanto de $\mathrm{Si}^{4+}$ por $\mathrm{Al}^{3+}$ na folha tetraédrica, quanto de $\mathrm{Mg}^{2+}$ por $\mathrm{Fe}^{3+}$ ou $\mathrm{Al}^{3+}$ na folha octaédrica. As substituições estabelecem uma carga na camada 2:1, carga essa que é balanceada pela existência de cátions interlamelares trocáveis (comumente magnésio, indicado na fórmula por [Mg] ) acompanhados por moléculas de água. Esse teor de água intercalada é variável, dependendo das condições ambientes. Quando rapidamente aquecida a temperaturas da ordem de $700^{\circ} \mathrm{C}$ ou superiores, a água intercalada transforma-se em vapor e desenvolve pressões elevadas no espaço Interlamelar, o que resulta na produção de um material de baixa densidade (chamado de vermiculita piroexpandida ou simplesmente vermiculita expandida) que é amplamente utilizado para aplicações em agronomia e horticultura, em isolamento térmico e em materiais absorventes para líquidos ambientalmente perigosos (HINDMAN, 1992; KLEIN; DUTROW, 2012).

Dependendo da origem geológica de uma vermiculita (tipo de rocha de origem e condições hidrogeológicas de alteração), a sua composição química pode variar. A Tabela 2 apresenta composições químicas de vermiculitas de várias ocorrências no Brasil e no mundo. 
Tabela 2 - Análises químicas (retiradas da literatura) de vermiculitas comerciais, de ocorrências brasileiras e internacionais

\begin{tabular}{|c|c|c|c|c|c|c|c|c|c|c|c|c|c|c|}
\hline $\begin{array}{l}\text { Óxidos } \\
(\%)\end{array}$ & $\begin{array}{l}\text { Catalão } \\
(\mathrm{GO}) * 1\end{array}$ & $\begin{array}{l}\text { Catalão } \\
(\mathrm{GO}){ }^{*} 1\end{array}$ & $\begin{array}{l}\text { Brumado } \\
(\mathrm{GO}){ }^{*} 1\end{array}$ & $\begin{array}{l}\text { Massapé } \\
(\mathrm{PI})^{\star} 2\end{array}$ & $\begin{array}{l}\text { Cerrado } \\
\text { III (GO) } \\
\star 3\end{array}$ & $\begin{array}{l}\text { Santa } \\
\text { Luzia } \\
(\mathrm{PB}){ }^{\star 2}\end{array}$ & $\begin{array}{l}\text { Sanclerlândia } \\
(\mathrm{GO})^{*} 2\end{array}$ & $\begin{array}{l}\text { São Luis dos } \\
\text { Montes Belos } \\
\text { (GO) *4 }\end{array}$ & $\begin{array}{l}\text { Palabora } \\
(\mathrm{AFS}){ }^{*} 1\end{array}$ & $\begin{array}{l}\text { Palabora } \\
(\text { AFS })^{* 2}\end{array}$ & $\begin{array}{l}\text { Munglinup } \\
\text { (AUS) *2 }\end{array}$ & $\begin{array}{l}\text { Santa } \\
\text { Ollala } \\
(\mathrm{ES}){ }^{*} 6\end{array}$ & $\begin{array}{l}\text { Louisa } \\
\text { (USA) } \\
* 2\end{array}$ & $\begin{array}{c}\text { Béni } \\
\text { Bousera } \\
(M A R)^{*} 5\end{array}$ \\
\hline $\mathrm{SiO}_{2}$ & 36,41 & 28,26 & 37,10 & 45,10 & 37,45 & 42,80 & 40,40 & 49,80 & 44,40 & 39,37 & 36,50 & 40,28 & 38,34 & 36,29 \\
\hline $\mathrm{Al}_{2} \mathrm{O}_{3}$ & 16,25 & 11,49 & 19,17 & 10,20 & 10,52 & 6,80 & 13,00 & 12,10 & 15,05 & 12,08 & 14,50 & 12,84 & 12,85 & 13,77 \\
\hline $\mathrm{Fe}_{2} \mathrm{O}_{3}$ & 11,31 & 20,86 & 5,14 & 5,80 & 6,60 & 6,70 & 8,50 & 5,95 & 4,15 & 5,45 & 10,50 & 3,72 & 8,80 & 5,24 \\
\hline $\mathrm{FeO}$ & 0,30 & 0,13 & 0,80 & $\ldots$ & $\ldots$ & $\cdots$ & $\ldots$ & $\ldots$ & 0,47 & 1,17 & $\ldots$ & 4,93 & & 1,80 \\
\hline $\mathrm{MgO}$ & 18,51 & 6,99 & 22,98 & 23,6 & 22,67 & 19,9 & 18,3 & 16,70 & 23,07 & 23,37 & 19,20 & 18,74 & 16,38 & 20,26 \\
\hline $\mathrm{CaO}$ & 0,59 & 2,70 & 2,04 & 3,60 & 0,38 & 0,56 & 1,40 & 0,80 & 1,27 & 1,46 & 0,21 & 0,19 & 1,12 & 0,18 \\
\hline $\mathrm{Na}_{2} \mathrm{O}$ & 0,10 & 1,36 & 1,35 & 0,10 & 0,31 & 1,00 & 2,50 & 0,30 & 0,73 & 0,80 & 2,00 & 0,10 & 1,72 & 0,06 \\
\hline $\mathrm{K}_{2} \mathrm{O}$ & 6,78 & 7,11 & 5,47 & 0,50 & 0,05 & 4,60 & 3,70 & 3,20 & 2,80 & 2,46 & 0,50 & 0,03 & 6,63 & 0,06 \\
\hline $\mathrm{TiO}_{2}$ & 2,73 & 7,86 & 0,33 & 0,70 & 2,05 & 0,86 & 1,00 & 0,90 & 1,04 & 1,25 & 0,75 & 0,24 & 1,66 & 2,66 \\
\hline $\mathrm{P}_{2} \mathrm{O}_{5}$ & nd & 5,76 & nd & $-\cdots$ & $-\cdots$ & $-\cdots$ & $\cdots$ & $-\cdots$ & 0,09 & $\cdots$ & $\cdots$ & $\cdots$ & $-\cdots$ & $-\cdots$ \\
\hline $\mathrm{Mn}_{2} \mathrm{O}_{3}$ & $-\cdots$ & $\ldots$ & $-\cdots$ & $\ldots$ & $-\cdots$ & $-\cdots$ & $\ldots$ & $\ldots$ & $\ldots$ & $-\cdots$ & $\ldots$ & $\ldots$ & $\ldots$ & $\ldots$ \\
\hline $\mathrm{Cr}_{2} \mathrm{O}_{3}$ & $\ldots$ & $\cdots$ & $\ldots$ & $\ldots$ & $\cdots$ & 0,45 & 0,31 & $\cdots$ & $\cdots$ & $\ldots$ & $\cdots$ & $\cdots$ & 0,23 & 0,01 \\
\hline $\mathrm{MnO}$ & $t$ & $t$ & $t$ & $-\cdots$ & $-\cdots$ & 0,11 & 0,12 & $\cdots$ & $t$ & 0,30 & 0,18 & 0,12 & 0,14 & 0,03 \\
\hline $\mathrm{NiO}$ & $-\cdots$ & $\cdots$ & $\cdots$ & $-\cdots$ & $-\cdots$ & 0,29 & 0,21 & $\cdots$ & $-\cdots$ & $-\cdots$ & $\cdots$ & $\cdots$ & $\cdots$ & $\cdots$ \\
\hline $\begin{array}{c}\text { Perda } \\
\text { ao fogo }\end{array}$ & 7,30 & 8,12 & 5,90 & 10,20 & 17,78 & 15,80 & 10,40 & 9,97 & 7,10 & 11,20 & 15,41 & 19,66 & 10,66 & 19,93 \\
\hline TOTAL & 100,28 & 100,64 & 100,28 & 99,80 & 97,81 & 99,87 & 99,84 & 99,72 & 100,17 & 98,91 & 99,75 & 100,85 & 98,53 & 100,61 \\
\hline
\end{tabular}

Fontes:*1 Souza Santos, P., 1992; *2 Ugarte et al., 2005; *3 Silva, 2006; *4 Ficha Técnica Brasil Minérios, $2012 ;{ }^{*} 5$ Badreddine et al., 2002; *6 Justo et al., 1987

AFS = África do Sul; AUS = Austrália; ES = Espanha; USA = Estados Unidos; MAR = Marrocos 
Processamentos industriais envolvendo moagem do mineral vermiculita, foram previamente estudados (BARABASZOVÁ; VALÁŠKOVÁ, 2013) fornecendo indicações que existe possibilidade para obtenção de partículas estáveis deste mineral após moagem.

Estudos realizados por Křistková e colaboradores (KŘíSTKOVÁ et al., 2004) indicaram que a vermiculita reduz seus níveis de reidratação quando combinado com matriz polimérica para formar compósitos. Estes níveis de reidratação dependem da relação de mistura entre o mineral vermiculita e a matriz da resina. Baseado neste estudo, ficou esclarecido que é possível a utilização de vermiculita em matrizes poliméricas formando compósitos e, estes compósitos tornam-se então impermeáveis ficando a vermiculita "blindada" a uma reidratação.

Compósitos formados por matriz polimérica combinadas com materiais inorgânicos foram estudados em diversas situações como por exemplo: preparação de resina epóxi com argila (LAN et al., 1995); preparação de compósitos de vermiculita com polipropileno (TJONG; MENG; HAY, 2002); preparação de compósitos com combinação de nanoargilas objetivando modificar propriedades mecânicas e permeabilidades de filmes (AULIN et al., 2012; KOTAL, BHOWMICK, 2015).

Alguns estudos citando a vermiculita na formação de compósitos também foram encontrados na literatura, como por exemplo: estudo de utilização de vermiculita na produção de nano compósitos com poliuretano (QIAN et al., 2011); estudo de nano compósitos de vermiculita em poliamida (TJONG; MENG; XU, 2002); compósitos de espumas de poliuretano com vermiculita (PATRO et al., 2008).

Em alguns trabalhos encontrados na literatura, foi verificado que as dimensões da carga mineral presente nos compósitos imprimiam propriedades específicas na formação de nano compósitos (CASERI, 2006). Estas características foram obtidas exclusivamente em função do tamanho das partículas presentes no compósito.

A adição de partículas de vermiculita, em tamanhos reduzidos, também modificam propriedades físicas de sistemas poliméricos onde estas partículas são adicionadas. Algumas propriedades podem ser melhoradas, ou comprometidas em 
função da entrada de partículas de vermiculita para formar compósitos (DAOFU , 2006).

\subsection{Sistemas uretânicos}

\subsubsection{Informações gerais sobre sistemas uretânicos}

Os sistemas uretânicos são originados a partir da reação entre os grupos $\mathrm{N}=\mathrm{C}=\mathrm{O}$ e os grupos $-\mathrm{OH}$ (ISMAIL et al. , 2016).

Os compostos obtidos por esta reação são denominados de sistemas uretânicos e, dependendo dos grupos químicos ligados ao grupo $-\mathrm{OH}$, existe uma espécie de subclassificação para esses sistemas, como por exemplo: se o grupo ligado ao grupo - $\mathrm{OH}$ for um grupo acrílico; os sistemas após reação entre os grupos $-\mathrm{N}=\mathrm{C}=\mathrm{O}$ e grupos $-\mathrm{OH}$ podem ser denominados de sistemas uretânicos acrílicos.

Uma outra subclasse para estes sistemas uretânicos também pode ser considerada em relação ao grupo ligado à estrutura $-\mathrm{N}=\mathrm{C}=\mathrm{O}$; neste caso os grupos podem ser compostos por estruturas químicas alifáticas ou por estruturas químicas contendo grupos aromáticos.

Para vernizes automotivos comumente são empregados isocianatos (moléculas contendo grupos $-\mathrm{N}=\mathrm{C}=\mathrm{O}$ ), ligados à estruturas químicas alifáticas e resinas diversas contendo grupos $-\mathrm{OH}$.

Se cada sistema reativo possuir mais de um grupo reativo na molécula, estes sistemas são denominados de sistemas poli funcionais e, as reações originam filmes com elevado grau de reticulação.

A reação destes grupos, $-\mathrm{N}=\mathrm{C}=\mathrm{O}$ e $-\mathrm{OH}$ (Figura 1), geram estruturas moleculares com elevado números de ligações cruzadas; formando, no caso dos vernizes, filmes com características de polímeros termofixos; com elevada dureza superficial e estrutural. 


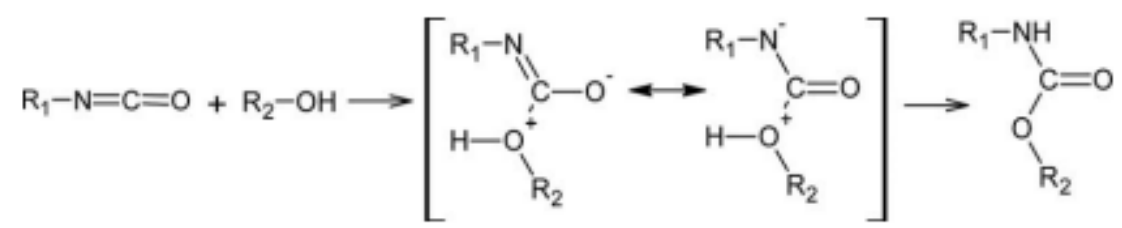

Figura 1 - Representação esquemática da reação entre os grupos $-\mathrm{N}=\mathrm{C}=\mathrm{O}$ e $-\mathrm{OH}$ (ISMAIL et al., 2016)

\subsubsection{Vernizes uretânicos}

Os vernizes são sistemas transparentes que formam filmes sobre superfícies sólidas. Nos filmes secos dos vernizes, são encontrados os agentes formadores do filme: as resinas.

A reação entre $\mathrm{R}-\mathrm{N}=\mathrm{C}=\mathrm{O}$ e R'-OH para a formação dos filmes dos vernizes uretânicos originam os sistemas poli uretânicos comumente encontrados no segmento de tintas e vernizes (FAZENDA et al., 2009).

Existe também a formação de filmes uretânicos sem a necessidade da ocorrência de reação química. Neste caso, os grupos $\mathrm{R}-\mathrm{N}=\mathrm{C}=\mathrm{O}$ e $\mathrm{R}^{\prime}-\mathrm{OH}$ foram previamente reagidos em reatores originando resinas que formam filmes de vernizes simplesmente pela evaporação do solvente. Um exemplo destas resinas são as dispersões uretânicas, resinas fornecidas em meio aquoso. Existem também, resinas uretânicas contendo grupos ativos que possibilitam cura por radiação ultravioleta.

No mercado de tintas e vernizes existe uma denominação típica para os filmes de revestimento de superfícies. Os filmes obtidos por reação química são denominados curados; filmes termofixos e filmes que se formam sem reação química são denominados de filmes secos ou filmes termoplásticos.

Os filmes de vernizes, já secos ou curados, podem conter compostos que não sejam apenas resinas na sua constituição - podem possuir aditivos para conferir propriedades específicas, como por exemplo resistência à intempéries.

$\mathrm{Na}$ Ciência dos Materiais, cada sistema composicional possui determinadas propriedades. Pode-se entender que cada propriedade é resultante da combinação 
de diversas matérias-primas, e também da relação de massa entre as matériasprimas da formulação.

A escolha ou a definição de uma matéria-prima para fazer parte da formulação de um determinado material pode interferir positivamente ou negativamente no desempenho em ensaios específicos ou em exposição ao meio ambiente (RAZIN et al., 2015).

A adição de substâncias a um verniz mudará suas propriedades finais, ou seja, as propriedades relacionadas ao filme seco ou curado. Para uma aplicação robusta e um desempenho robusto de quaisquer materiais formulados o design da sua composição é de primordial importância (GEURINK et al., 2006).

O setor de pintura automotiva segue procedimentos de aplicação para vernizes e para tintas que imprimam determinadas características de superfície. Uma pintura automotiva (Figura 2) é composta de revestimentos estratificados como eletro revestimento, primers (tinta de fundo), tinta base (revestimento responsável pela cor final) e verniz, que é o último revestimento de uma pintura automotiva. (ADAMSONS, 2000).

Para atendimento das especificações das áreas de projetos, as pinturas do setor automotivo deverão atender requisitos de alto desempenho que são as características técnicas essenciais para atendimento das necessidades dos projetos criados por engenharia estrutural (CHATTOPADHYAY; RAJU, 2007). Neste contexto, a entrada de novos materiais como é o caso da vermiculita processada, poderá imprimir propriedades que estejam dentro destas exigências dos projetos automotivos. 


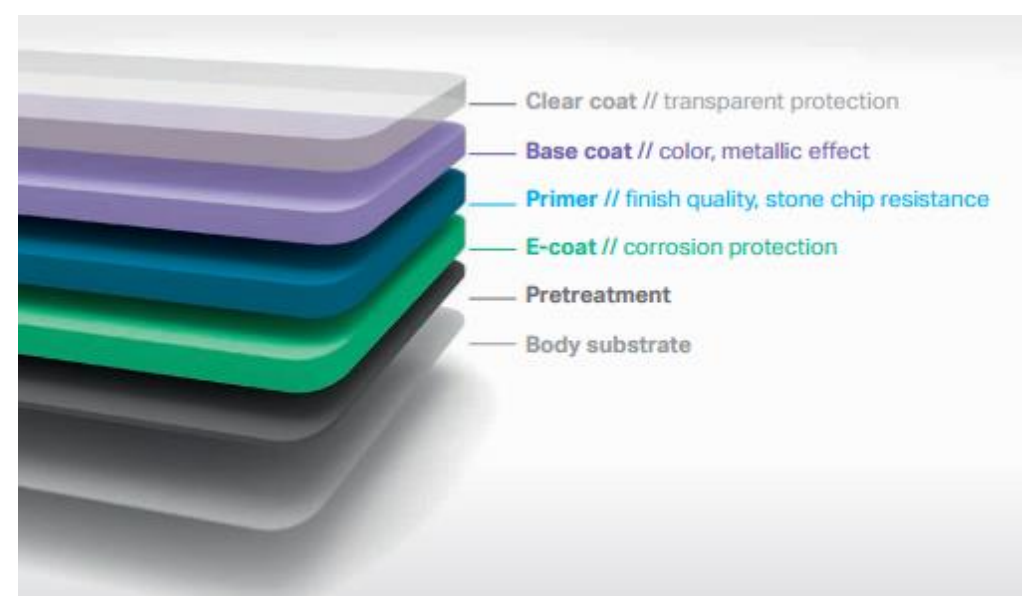

Figura 2 - Esquema de uma aplicação automotiva

Fonte; adaptado de https://www.coatings.covestro.com/Applications/AutomotiveTransportation.aspx; capturado em 11/06/2017

Vernizes podem possuir diversas combinações de resinas em sua formulação resultando nos vernizes mono componente e vernizes de dois componentes comumente chamados no mercado automotivo de vernizes 2K (COLLONG et al., 2002).

Nos vernizes $2 \mathrm{~K}$, ou bi-componentes, o sistema é fornecido em duas composições distintas, e estas são misturadas no momento da aplicação, onde inicia-se uma reação química. Na Figura 3, é mostrada uma reação para a formação de um filme uretânico bi-componente.

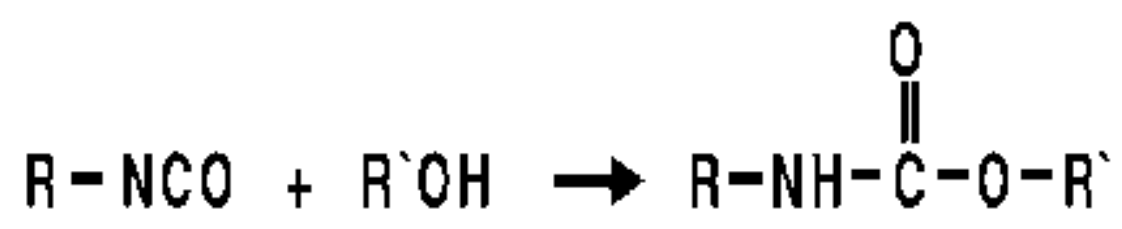

Figura 3 - Reações de grupos $\mathrm{NCO}$ com grupos $\mathrm{OH}$ Fonte: COLLONG et al., 2002

Os filmes de vernizes uretânicos resultantes desta reação química são tidos como filmes com resistências químicas e físicas excepcionais. No lado esquerdo da reação os grupos $R$ e $R^{\prime}$ devem ser compostos por estruturas polifuncionais para originar filmes altamente reticulados com elevada dureza superficial e estrutural, características típicas de revestimentos automotivos, e devem também possuir resistências químicas e físicas de acordo com as normas e exigências da engenharia de projetos de montadoras. 


\section{MATERIAIS E MÉTODOS}

\subsection{Materiais}

A vermiculita expandida utilizada neste trabalho é uma vermiculita brasileira originária de São Luís dos Montes Belos, no estado de Goiás (amostra obtida da empresa Brasil Minérios).

Os demais materiais utilizados foram selecionados conforme disponibilidade de mercado:

- verniz Duxone 0904, formulado com resina acrílica hidroxilada e agente de cura "catalisador para verniz 0904", composto contendo isocianatos alifáticos; materiais fabricados pela empresa Axalta Coating Systems;

- tintas de cores prata e preta, à base de solvente, produtos comumente encontrados nas lojas de repintura automotiva; materiais fabricados pela empresa Axalta Coating Systems;

- dispersão aquosa de poliuretano alifático em meio básico com 34 \% de teor de não-voláteis; dióxido de silício hidrófilo; tamanho de partícula menor que 20 nm; materiais fornecidos pela Empresa Chem4u Indústria e Comércio Ltda;

- chapas de aço carbono 1020 com tratamento de fosfato de zinco fornecido pela Empresa Aquarela de Acabamentos de Superfícies Ltda;

- chapas de aço 1020, com tratamento estrutural de montadora automotiva contendo os revestimentos: fosfato de zinco, fundo e-coat e tintas de fundo, cinza e preto respectivamente e, verniz acrílico automotivo; materiais fornecidos pelos laboratórios da Axalta Coating System;

- Cloreto de sódio, ( $\mathrm{NaCl})$, grau analítico;

- Acetato de butilglicol (1-acetoxi-2-butoxietano), grau analítico;

- Butilglicol (2-butoxietanol), grau analítico. 


\subsection{Métodos}

\subsubsection{Caracterização da vermiculita}

A vermiculita piroexpandida utilizada nesta Tese foi caracterizada pelas técnicas:

- Análise química (por fluorescência de raios X - FRX);

- Difração de raios X (DRX);

- Microscopia eletrônica de varredura (MEV).

- Determinação do tamanho de partícula por espalhamento de luz.

- Determinação da densidade real por picnometria de hélio.

\subsubsection{Análise química por fluorescência de raios $\mathrm{X}$}

A análise química da vermiculita foi feita por fluorescência de raios $X$ a partir de amostra da vermiculita piroexpandida de partida moída e passante em malha ABNT \# 100. Os teores foram determinados no Laboratório de Caracterização Tecnológica (LCT) do Departamento de Engenharia de Minas e Petróleo da Escola Politécnica da USP, em amostra fundida com tetraborato de lítio anidro, na calibração ROC-1 (Rochas), relativa a análise quantitativa por comparação com materiais de referência certificados, em espectrômetro de fluorescência de raios $X$, marca Bruker, modelo S8 Tiger. A perda ao fogo (PF) foi efetuada a $1020^{\circ} \mathrm{C}$ por $2 \mathrm{~h}$.

\subsubsection{Difração de raios X}

As amostras, tanto do material original, quanto as amostras moídas do mineral, foram analisadas na forma de pós obtidos após secagem em estufa elétrica com circulação de ar por $48 \mathrm{~h}$ à temperatura de $160^{\circ} \mathrm{C}$. Os aglomerados obtidos após secagem foram triturados manualmente em almofariz de cerâmica com pistilo também de cerâmica. O pó foi peneirado em peneira ABNT \#130. Para essa análise foi utilizado difratômetro de raios $X$ Philips X'PERT MPD, pertencente ao LPSS/EPUSP, equipado com uma fonte de Cu (radiação $K \alpha, \lambda=1,54186 \AA$ ), operado 
em $40 \mathrm{kV}$ e $40 \mathrm{~mA}$, com varredura de passo $0,02^{\circ}(2 \theta)$ e tempo de acumulação de 1 s por passo, entre $3^{\circ}(2 \theta)$ e $90^{\circ}(2 \theta)$.

\subsubsection{Análise da morfologia das partículas por microscopia eletrônica de varredura (MEV)}

As análises de MEV foram realizadas em dois equipamentos diferentes:

- microscópio eletrônico de varredura Jeol 6460LV do Instituto de Física da Universidade de São Paulo;

- modelo FEl Inspect F50, pertencente ao PMT-EPUSP, usando $5 \mathrm{kV}$ de tensão; nesse caso, pós secos foram depositados em suportes metálicos de amostras cobertos com uma fita adesiva de dupla face de carbono, recebendo a seguir um recobrimento de ouro.

\subsubsection{Determinação do tamanho de partícula por espalhamento de luz}

As amostras, tanto o material original, quanto as amostras moídas foram avaliadas por espalhamento de Luz - LASER no equipamento 90 Plus-Zeta (Brookhaven Instruments Corporation, Holtsville, EUA); onde os resultados correspondem à média dos diâmetros das partículas; o equipamento foi cedido pela Empresa Chem4u Indústria e Comércio Ltda.

\subsubsection{Determinação da densidade real por picnometria de hélio}

A determinação da densidade real $\left(\mathrm{em} \mathrm{g} / \mathrm{cm}^{3}\right)$ dos pós secos da vermiculita foi feita por picnometria de hélio. Foi utilizado um picnômetro Quantachrome modelo MVP 5DC, pertencente ao Laboratório de Microestrutura e Sustentabilidade do Departamento de Construção Civil da EPUSP (LME-PCC-EPUSP). Os resultados representam uma média de 5 determinações.

\subsubsection{Análise de cor}

A análise de cor dos sistemas contendo vermiculita foi feita utilizando os equipamentos: 
- Espectrofotômetro Multiangular MA68II fabricado por X-Rite Inc pertencente à Empresa Axalta Coatings, equipado com o Software X-RiteColorMaster Metallix.

- Refletômetro Espectrofotômetro Data Color $600^{\mathrm{TM}}$ pertencente à Empresa Cromex S.A.

\subsubsection{Processo de moagem para a vermiculita expandida.}

Os passos apresentados a seguir foram realizados para preparo da vermiculita processada.

\subsubsection{Preparo das bases de moagem}

Base1: Base de moagem utilizando o solvente orgânico butilglicol como meio de processamento

A escolha do solvente butilglicol foi devida à compatibilidade deste solvente com a água e também por apresentar compatibilidade com as resinas em estudo na Tese. Esta característica de compatibilidade possibilitou a incorporação dos materiais processados em butilglicol tanto em meios aquosos, quanto em meios nãoaquosos, não necessitando assim, outros processos complexos para extração de solventes do meio. A relação de preparo da base de moagem 1 da vermiculita expandida foi de 80 partes da vermiculita expandida para 20 partes de butilglicol (partes em massa).

Base 2: Base de moagem utilizando água desmineralizada como meio de processamento

A relação de preparo da base de moagem 2 da vermiculita expandida foi de 80 partes da vermiculita expandida para 20 partes de água desmineralizada (partes em massa).

Bases 3 e 4: Bases de moagem utilizando vermiculita calcinada e acetato de butilglicol como meio de processamento 
Também foi feito o processamento de vermiculita expandida submetida a uma calcinação adicional a $1000^{\circ} \mathrm{C}$, antes do processamento. Essa calcinação foi feita porque se verificou que o processo de piroexpansão realizado na indústria não foi capaz de desidroxilar completamente a vermiculita; além disso, o material piroexpandido adsorve água. A eliminação da água do sistema justifica-se pelo interesse em evitar ao máximo a ocorrência de reações paralelas entre os grupos $\mathrm{N}=\mathrm{C}=\mathrm{O}$, presentes no endurecedor, e a água adsorvida na vermiculita expandida recebida para moagem.

A vermiculita calcinada por $3 \mathrm{~h}$ a $1000^{\circ} \mathrm{C}$ teve uma perda de massa correspondente a 17,9\%. Essa perda que pode ser atribuída tanto à água gerada na desidroxilação da vermiculita, que não teria ocorrido em sua totalidade no processo de piro expansão, quanto à existência de água adsorvida no material piroexpandido.

Essa vermiculita calcinada também foi processada em outro solvente orgânico, o acetato de butilglicol, solvente isento de grupos reativos na estrutura da molécula, em substituição ao butilglicol (2-butoxietanol, que contém um grupo $-\mathrm{OH}$ na sua estrutura), para ensaios de investigação da reação entre os grupos $-\mathrm{OH}$ e $-\mathrm{N}=\mathrm{C}=\mathrm{O}$. A escolha desse solvente também foi devida à sua compatibilidade com a resina acrílica escolhida para o estudo da aceleração reacional.

Essas duas variáveis introduzidas - moagem em acetato de butilglicol e calcinação a $1000^{\circ} \mathrm{C}$ - resultaram em mais duas bases de moagem, as bases 3 (contendo vermiculita expandida não calcinada a $1000^{\circ} \mathrm{C}$ ) e 4 (contendo vermiculita expandida calcinada a $1000^{\circ} \mathrm{C}$ ).

A relação de preparo das bases de moagem da vermiculita expandida para processamento foi de 80 partes da vermiculita expandida para 20 partes de acetado de butilglicol; partes em massa.

Os equipamentos utilizados para mistura dos materiais para as duas bases de moagem foram béqueres plásticos de 2 litros. A homogeneização foi manual, empregando-se uma espátula de inox. 


\subsubsection{Processo de Moagem}

Esta etapa serviu para obtenção de diferentes tamanhos médios de partículas de vermiculita processada para cada base de moagem.

Para moagem das bases foi utilizado um moinho de "batelada" construído na empresa Chem4u; tanto o projeto de construção do moinho, quanto detalhes específicos da rota de processamento serão alvo de patente da empresa, não podendo, portanto, ser detalhados nesta Tese.

Um dos objetivos desta Tese está relacionado com a obtenção de partículas vermiculita expandida com tamanho reduzido. Para atender o objetivo de se obter diferentes tamanhos para as partículas de vermiculita foram utilizados quatro tempos de processamento.

Para a base de moagem 1, com solvente orgânico, foram aplicadas moagens por 8 horas e 12 horas, e para a base de moagem 2, com água desmineralizada, foram efetuadas moagens por 2 horas e 4 horas.

Os primeiros sistemas moídos foram os sistemas contendo o solvente butilglicol. Ensaios preliminares aplicados a estas moagens tiveram resultados satisfatórios. Sendo então, o acetato de butilglicol também um solvente orgânico, os mesmos tamanhos médios para as partículas de vermiculita foram almejados e conseguidos.

Para atender aos propósitos definidos nesta Tese; as moagens em meio aquoso tiveram como objetivo outros tamanhos médios para as partículas de vermiculita.processada

Na Figura 4 é mostrado o esquema simplificado do processamento aplicado à vermiculita expandida. Os meios utilizados nesta fase foram os solventes butilglicol e água. 


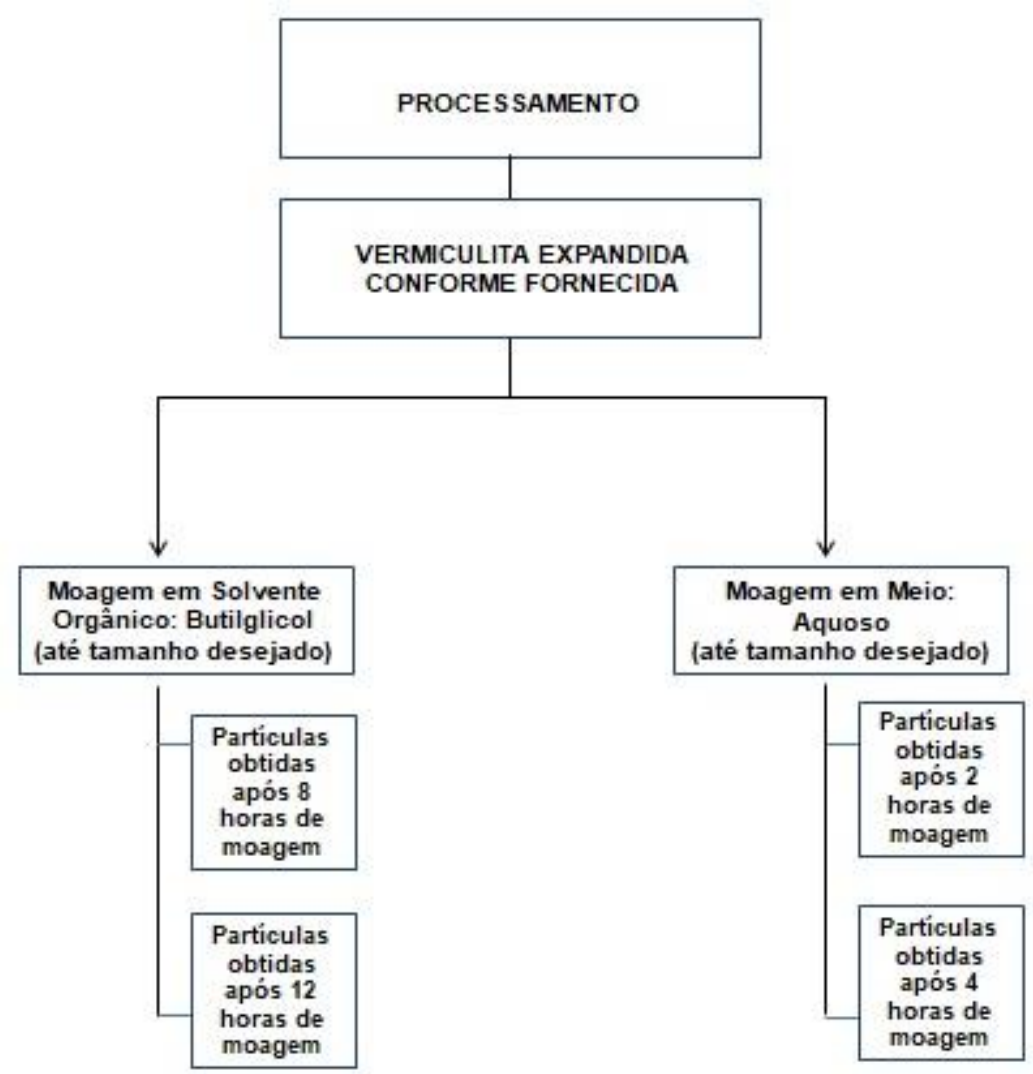

Figura 4 - Representação esquemática dos processamentos de moagem envolvendo a vermiculita expandida em meios butilglicol e água Fonte: Esquema desenhado pelo autor

Na Figura 5 é mostrado o esquema simplificado do processamento aplicado às bases 3 e 4 (esta última, contendo vermiculita expandida calcinada).

O meio utilizado nesta fase foi o acetato de butilglicol. Para estas bases, foram definidos dois tempos de processamento; 8 horas e 12 horas. 


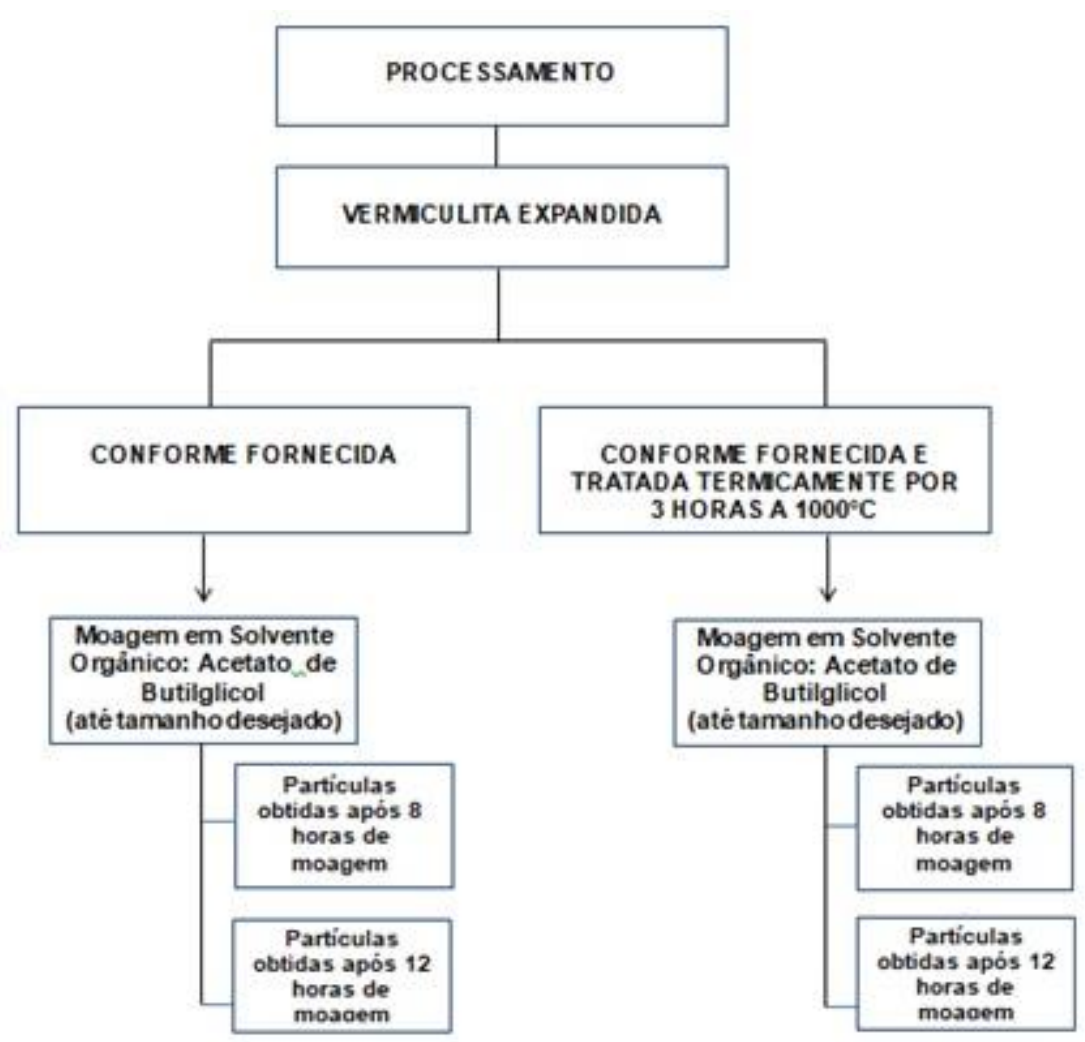

Figura 5 - Representação esquemática dos processamentos de moagem envolvendo a vermiculita expandida em solvente orgânico acetato de butilglicol

Fonte: Esquema desenhado pelo Autor

Resumindo, após processamento das bases de moagem da vermiculita expandida foram designadas as seguintes alíquotas de trabalho para a Tese:

- Alíquota de material processado em meio aquoso por 2 horas; tamanho médio $626 \mathrm{~nm}$.

- Alíquota de material processado em meio aquoso por 4horas ; tamanho médio $479 \mathrm{~nm}$.

- Alíquota de material processado em meio butilglicol por 8 horas; tamanho médio 195,5 nm.

- Alíquota de material processado em meio butilglicol por 12 horas; tamanho médio $170,9 \mathrm{~nm}$.

- Alíquota de material aquecido a $1000^{\circ} \mathrm{C}$ processado em meio acetato de butilglicol por 8 horas; tamanho médio 195,5 nm.

- Alíquota de material aquecido a $1000^{\circ} \mathrm{C}$ processado em meio acetato de butilglicol por 12 horas; tamanho médio $170,9 \mathrm{~nm}$. 
Observação: Durante o período decorrido após os processamentos de cada alíquota, até as finalizações das etapas de ensaios desta Tese, as alíquotas dos materiais processados, em meio aquoso e em meio de solvente orgânico, se conservaram estáveis por períodos de 6 meses e, em algumas situações extrapolando este tempo de estabilidade.

4.2.3 Preparação para verificação de cor das partículas de vermiculita processada: somente partículas puras e partículas com resina uretânica.

A cor é uma propriedade inerente aos materiais; principalmente para materiais líquidos e sólidos quando estes materiais interagem com a luz visível.

A verificação de cor, proposta neste item, refere-se a avaliação do surgimento de cor devido a adição de partículas de vermiculita processada em vernizes uretânicos.

Para análise da existência de cor nos sistemas formados pela vermiculita processada, foram estudados primeiramente dois sistemas, com e sem resina, conforme apresentados nas Tabelas 3 e 4.

O preparo das misturas da dispersão uretânica e vermiculitas foi efetuado em béqueres de polipropileno de $400 \mathrm{~mL}$. As misturas foram homogeneizadas manualmente com espátula de inox para posterior deposição em placas de Petri. Cada mistura foi vertida em placas de Petri de poliestireno cristal até altura aproximada de 3 milímetros. As placas de Petri contendo as misturas e moagem original foram mantidas em estufa elétrica com circulação de ar por um período de $96 \mathrm{~h}$ a $30^{\circ} \mathrm{C}$. Durante esse processo de secagem, as placas de Petri foram mantidas abertas com o objetivo de facilitar a evaporação da água e possíveis voláteis do sistema.

As relações em massa dos não voláteis da resina uretânica e das vermiculitas empregadas para preparo dos corpos de prova, são apresentados nas Tabelas $3 \mathrm{e}$ 4. 
Tabela 3 - Relação em massa para os corpos de prova contendo dispersão uretânica e vermiculita processada em meio aquoso $(626 \mathrm{~nm})$

\begin{tabular}{|l|c|c|c|c|}
\hline \multicolumn{1}{|c|}{ Corpos de prova } & $\begin{array}{c}\text { Vermiculita } \\
\text { pura }\end{array}$ & VP 245 C & VP 245 D & VP 245 E \\
\hline $\begin{array}{l}\text { Dispersão uretânica. } \\
\text { matéria não volátil (g) }\end{array}$ & 0,00 & 100,00 & 100,00 & 100,00 \\
\hline $\begin{array}{l}\text { Vermiculita processada } \mathbf{6 2 6} \mathbf{~ n m} \\
\text { matéria não volátil (g) }\end{array}$ & 20,56 & 25,00 & 50,00 & 100,00 \\
\hline $\begin{array}{l}\text { Relação: vermiculita processada } \\
\mathbf{6 2 6} \mathbf{~ n m ~ e ~ d i s p e r s a ̃ o ~ u r e t a ̂ n i c a ~} \\
\text { (g/g) }\end{array}$ & $\begin{array}{c}\text { Somente } \\
\text { vermiculita } \\
\text { processada }\end{array}$ & 0,25 & 0,50 & 1,00 \\
\hline
\end{tabular}

Fonte: O Autor

Tabela 4 - Relação em massa para os corpos de prova contendo dispersão uretânica e vermiculita processada em meio aquoso $(479 \mathrm{~nm})$

\begin{tabular}{|l|c|c|c|c|}
\hline \multicolumn{1}{|c|}{ Corpos de prova } & $\begin{array}{c}\text { Vermiculita } \\
\text { pura }\end{array}$ & VP 246 C & VP 246 D & VP 246 E \\
\hline $\begin{array}{l}\text { Dispersão uretânica. } \\
\text { matéria não volátil (g) }\end{array}$ & 0,00 & 100,00 & 100,00 & 100,00 \\
\hline $\begin{array}{l}\text { Vermiculita processada } \mathbf{4 7 9} \mathbf{~ n m} \\
\text { matéria não volátil (g) }\end{array}$ & 20,56 & 25,00 & 50,00 & 100,00 \\
\hline $\begin{array}{l}\text { Relação: vermiculita processada } \\
\mathbf{4 7 9} \mathbf{~ n m ~ e ~ d i s p e r s a ̃ o ~ u r e t a ̂ n i c a ~} \\
\text { (g/g) }\end{array}$ & $\begin{array}{c}\text { Somente } \\
\text { vermiculita } \\
\text { processada }\end{array}$ & 0,25 & 0,50 & 1,00 \\
\hline
\end{tabular}

Fonte: O Autor

\subsubsection{Preparação dos vernizes para aplicação sobre tintas de cores preta e prata}

Os vernizes uretânicos contendo partículas de vermiculita processada quando aplicados sobre uma superfície formam filmes sólidos, possibilitando a análise de cor. Os filmes de vernizes resultantes da combinação de vermiculita, na sua forma processada, com resina uretânica foram avaliados sobre diversas superfícies. Neste trabalho, as cores das superfícies que receberam a aplicação de verniz foram de cor prata e de cor preta; ou seja, os vernizes foram aplicados diretamente sobre os filmes de tintas de cores prata e preta.

As cores das tintas foram escolhidas devido ao efeito refletivo promovido pelas partículas de alumínio presente na composição da cor prata, que de certa forma facilitaria um retorno maior da luz incidente e, consequentemente, maior informação 
sobre as possíveis interações das partículas de vermiculita com a luz. A cor preta foi escolhida exatamente pela tendência oposta de reflexão da luz.

Os tamanhos médios das partículas escolhidas para serem adicionadas aos vernizes teriam que ser os menores possíveis para não provocar perda de aparência do filme contendo partículas de vermiculita processada, inviabilizando a comparação entre os sistemas com e sem partículas de vermiculita. Neste caso, foram utilizadas as partículas processadas em butilglicol.

Para análise de cor dos vernizes contendo partículas de vermiculita, os procedimentos de preparo seguiram as recomendações do fabricante. Neste caso o verniz, sistema de filme transparente, está sendo o carreador para as partículas de vermiculita processada.

O preparo das misturas do verniz uretânico e vermiculita (Tabelas 5 e 6), foi efetuado em béqueres de polipropileno de $400 \mathrm{~mL}$. As misturas foram homogeneizadas manualmente com uma espátula de aço inox para posterior aplicação no sistema robotizado. 
Tabela 5 - Preparo do verniz para aplicação sobre tinta prata

\begin{tabular}{|c|c|c|c|c|c|c|}
\hline $\begin{array}{c}\text { Cor da tinta } \\
\text { aplicada }\end{array}$ & \multicolumn{3}{|c|}{ Características das amostras } & \multicolumn{3}{|c|}{ Composição das amostras para aplicação. } \\
\hline \multirow{8}{*}{ PRATA } & $\begin{array}{l}\text { Tempo de } \\
\text { moagem } \\
(\mathrm{h})\end{array}$ & $\begin{array}{c}\text { Tamanho } \\
\text { das } \\
\text { partículas } \\
\text { de } \\
\text { vermiculita } \\
(\mathrm{nm})\end{array}$ & $\begin{array}{l}\text { Codificação } \\
\text { das } \\
\text { amostras }\end{array}$ & $\begin{array}{c}\text { Quantidade de } \\
\text { verniz (g). } \\
\text { Conforme fornecido }\end{array}$ & $\begin{array}{l}\text { Quantidade de } \\
\text { agente de cura } \\
\text { (g) conforme } \\
\text { fornecido }\end{array}$ & $\begin{array}{c}\text { Quantidade } \\
\text { de vermiculita } \\
\text { processada } \\
\text { (g) de matéria } \\
\text { não volátil }\end{array}$ \\
\hline & $\begin{array}{l}\text { Sistema } \\
\text { sem } \\
\text { partículas }\end{array}$ & - & PA_B_0 & 100 & 20 & 0 \\
\hline & \multirow{3}{*}{8 horas } & \multirow{3}{*}{195,5} & PA_2H_0,5 & 100 & 20 & 0,5 \\
\hline & & & PA_2H_1,0 & 100 & 20 & 1,0 \\
\hline & & & PA_2H_2,0 & 100 & 20 & 2,0 \\
\hline & \multirow{3}{*}{12 horas } & \multirow{3}{*}{170,9} & PA_12H_0,5 & 100 & 20 & 0,5 \\
\hline & & & PA_12H_1,0 & 100 & 20 & 1,0 \\
\hline & & & PA_12H_2,0 & 100 & 20 & 2,0 \\
\hline
\end{tabular}

Fonte: O Autor

Tabela 6 - Preparo do verniz para aplicação sobre tinta preta

\begin{tabular}{|c|c|c|c|c|c|c|}
\hline \multicolumn{7}{|c|}{ Composição das amostras para aplicação. } \\
\hline \multirow{8}{*}{ PRETA } & $\begin{array}{l}\text { Tempo de } \\
\text { moagem } \\
(\mathrm{h})\end{array}$ & $\begin{array}{l}\text { Tamanho } \\
\text { das } \\
\text { partículas } \\
\text { de } \\
\text { vermiculita } \\
(\mathrm{nm})\end{array}$ & $\begin{array}{l}\text { Codificação } \\
\text { das } \\
\text { amostras }\end{array}$ & $\begin{array}{c}\text { Quantidade de } \\
\text { verniz }(\mathrm{g}) . \\
\text { Conforme fornecido }\end{array}$ & $\begin{array}{l}\text { Quantidade de } \\
\text { agente de cura } \\
\text { (g) conforme } \\
\text { fornecido }\end{array}$ & $\begin{array}{c}\text { Quantidade } \\
\text { de vermiculita } \\
\text { processada } \\
\text { (g) de matéria } \\
\text { não volátil }\end{array}$ \\
\hline & $\begin{array}{l}\text { Sistema } \\
\text { sem } \\
\text { partículas }\end{array}$ & - & PA_B_0 & 100 & 20 & 0 \\
\hline & \multirow{3}{*}{8 horas } & \multirow{3}{*}{195,5} & PA_2H_0,5 & 100 & 20 & 0,5 \\
\hline & & & PA_2H_1,0 & 100 & 20 & 1,0 \\
\hline & & & PA_2H_2,0 & 100 & 20 & 2,0 \\
\hline & \multirow{3}{*}{12 horas } & \multirow{3}{*}{170,9} & PA_12H_0,5 & 100 & 20 & 0,5 \\
\hline & & & PA_12H_1,0 & 100 & 20 & 1,0 \\
\hline & & & PA_12H_2,0 & 100 & 20 & 2,0 \\
\hline
\end{tabular}




\subsubsection{Sistema aplicador}

Para aplicação dos sistemas tinta e verniz foi utilizado o equipamento de aplicação Robot Semi Tech Durr Modelo ECO Bell 2 (Figura 6), pertencente à Empresa Axalta Coatings. Este equipamento é muito utilizado em laboratórios de desenvolvimento de tintas e vernizes para simular as condições reais das linhas automotivas e industriais.

Este equipamento consiste de um atomizador de alta rotação, um sistema de dosagem e uma unidade de controle. Este equipamento permite pintar peças pequenas e grandes e possui transferência até $95 \%$, condição considerada de elevada eficiência para os processos de aplicação.

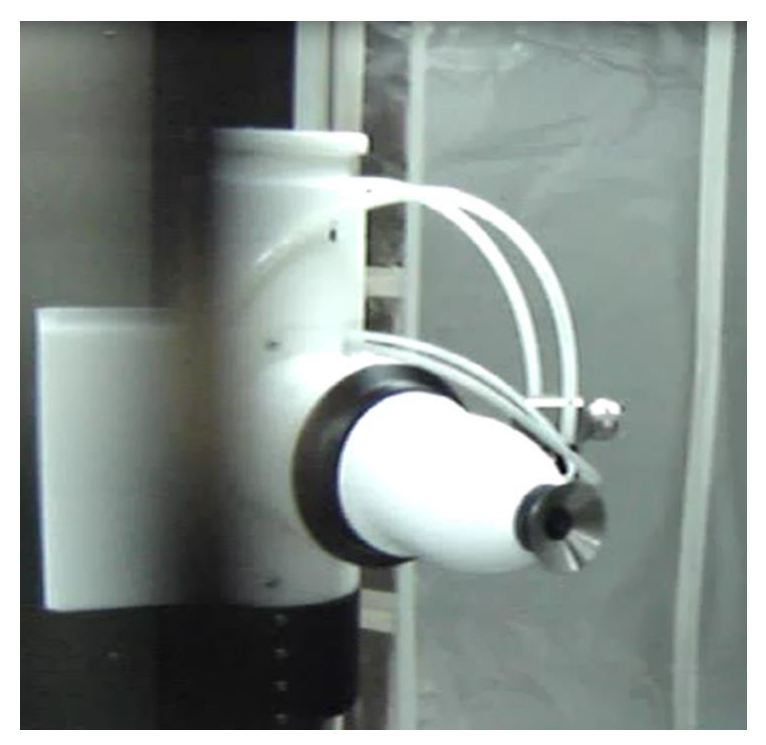

Figura 6 - Equipamento Robot Semi Tech Durr Modelo ECO Bell 2 Serrilhado utilizado para aplicação das tintas e do verniz sobre as chapas de cor preta e prata

Fonte Axalta.Co

As adições das partículas de vermiculita não alteraram as condições de aplicabilidade dos vernizes pelo equipamento aplicador. Os painéis foram aplicados verticalmente conforme procedimento operacional do equipamento.

Após as aplicações dos vernizes sobre as respectivas tintas prata e preta, os painéis foram mantidos na posição horizontal, em temperatura de $25^{\circ} \mathrm{C}$ por 40 minutos e, em seguida, foram acondicionados horizontalmente em estufa de circulação de ar. 
Os painéis aplicados foram curados por 30 minutos a $80^{\circ} \mathrm{C}$. Após a cura na estufa, os painéis foram mantidos por $72 \mathrm{~h}$ à temperatura ambiente, a uma umidade relativa do ar entre $60 \%$ e $80 \%$, para posterior avaliação das características de brilho, cor, dureza e aspecto.

\subsubsection{Preparação dos vernizes para investigação de aceleração reacional}

Para avaliação de aceleração reacional nos sistemas de uretano de dois componentes promovida pela presença de partículas de vermiculita foram utilizadas partículas processadas conforme esquema mostrado na Figura 5. Essas partículas foram empregadas em misturas preparadas manualmente conforme procedimentos indicados pelo fornecedor do verniz e do endurecedor.

O preparo destas misturas compostas pelo verniz, endurecedor, partículas de vermiculita processada e solvente, foi efetuado em béqueres de polipropileno de 400 $\mathrm{mL}$. Todos os sistemas, com e sem partículas de vermiculita, foram homogeneizados manualmente com espátula de aço inoxidável em conformidade com as recomendações do fornecedor.

As massas utilizadas para o preparo das misturas empregadas nos ensaios para as avaliações da aceleração reacional são apresentados nas Tabelas de 7 a 10.

Os ensaios de aceleração reacional constantes da Tabela 7, foram preparados com vermiculita processada $(195,5 \mathrm{~nm})$ sem tratamento térmico a $1000^{\circ} \mathrm{C}$ em mufla. 
Tabela 7 - Massas (g) utilizadas para o preparo das amostras para ensaio de aceleração reacional da vermiculita processada sem tratamento térmico a $1000^{\circ} \mathrm{C}$ em mufla e moída em acetato de butilglicol $(195,5 \mathrm{~nm})$

\begin{tabular}{|c|c|c|c|c|c|c|}
\hline $\begin{array}{c}\text { Ensaios de aceleração } \\
\text { reacional }\end{array}$ & PV 0 & $\begin{array}{c}\text { PV 1 } \\
\text { (SM) }\end{array}$ & $\begin{array}{c}\text { PV 2 } \\
\text { (SM) }\end{array}$ & $\begin{array}{c}\text { PV 3 } \\
\text { (SM) }\end{array}$ & $\begin{array}{c}\text { PV 4 } \\
\text { (SM) }\end{array}$ & $\begin{array}{c}\text { PV 5 } \\
\text { (SM) }\end{array}$ \\
\hline $\begin{array}{c}\text { Verniz DX 0904 como } \\
\text { fornecido }\end{array}$ & 100,00 & 100,00 & 100,00 & 100,00 & 100,00 & 100,00 \\
\hline $\begin{array}{c}\text { Endurecedor DX 194 como } \\
\text { fornecido }\end{array}$ & 20,00 & 20,00 & 20,00 & 20,00 & 20,00 & 20,00 \\
\hline Acetato de butilglicol & 10,12 & 9,71 & 9,30 & 8,48 & 6,84 & 3,55 \\
\hline $\begin{array}{c}\text { Dispersão de vermiculita } \\
(195,5 \text { nm) - concentração } \\
\text { de 23,34 \% }\end{array}$ & 0 & 0,54 & 1,07 & 2,14 & 4,28 & 8,57 \\
\hline $\begin{array}{c}\text { Concentração de vermiculita } \\
\text { (g/120g } \\
\text { verniz+endurecedor) }\end{array}$ & 0 & 0,125 & 0,25 & 0,50 & 1,00 & 2,00 \\
\hline
\end{tabular}

SM-sem tratamento térmico

Fonte: O Autor

Os ensaios de aceleração reacional apresentados na Tabela 8 foram preparados com vermiculita processada sem tratamento térmico a $1000^{\circ} \mathrm{C}$ em mufla. Recordando: o tratamento térmico a $1000^{\circ} \mathrm{C}$ em mufla foi realizado com o objetivo eliminar as moléculas de água adsorvidas à vermiculita e expor diretamente os metais presentes na rede cristalina para que possam atuar de forma mais efetiva no meio contendo verniz e endurecedor.

Tabela 8 - Massas ( $\mathrm{g}$ ) utilizadas para o preparo das amostras para ensaio de aceleração reacional da vermiculita processada sem tratamento térmico a $1000^{\circ} \mathrm{C}$ em mufla e moída com acetato de butilglicol $(170,9 \mathrm{~nm})$

\begin{tabular}{|c|c|c|c|c|c|c|}
\hline $\begin{array}{c}\text { Ensaios de aceleração } \\
\text { reacional }\end{array}$ & PV 0 & $\begin{array}{c}\text { PV 6 } \\
\text { (SM) }\end{array}$ & $\begin{array}{c}\text { PV 7 } \\
\text { (SM) }\end{array}$ & $\begin{array}{c}\text { PV 8 } \\
\text { (SM) }\end{array}$ & $\begin{array}{c}\text { PV 9 } \\
\text { (SM) }\end{array}$ & $\begin{array}{c}\text { PV 10 } \\
\text { (SM) }\end{array}$ \\
\hline Verniz DX 0904 como fornecido & 100,00 & 100,00 & 100,00 & 100,00 & 100,00 & 100,00 \\
\hline $\begin{array}{c}\text { Endurecedor DX 194 como } \\
\text { fornecido }\end{array}$ & 20,00 & 20,00 & 20,00 & 20,00 & 20,00 & 20,00 \\
\hline Acetato de butilglicol & 10,12 & 9,49 & 8,85 & 7,59 & 5,05 & 0,00 \\
\hline $\begin{array}{c}\text { Dispersão de vermiculita (170,9 } \\
\text { nm) - concentração de 16,50 \%) }\end{array}$ & 0,00 & 0,76 & 1,52 & 3,03 & 6,06 & 12,12 \\
\hline $\begin{array}{c}\text { Concentração de vermiculita } \\
\text { (g/120g verniz+endurecedor) }\end{array}$ & 0,00 & 0,125 & 0,25 & 0,50 & 1,00 & 2,00 \\
\hline
\end{tabular}

SM - sem tratamento térmico

Fonte: O Autor 
Os ensaios de aceleração reacional constantes das Tabela 9 e 10 foram realizados utilizando a vermiculita processada $(195,5 \mathrm{~nm})$ com tratamento térmico a $1000^{\circ} \mathrm{C}$ em mufla.

Tabela 9 - Massas (g) utilizadas para o preparo das amostras para ensaio de aceleração reacional da vermiculita processada com tratamento térmico em mufla a $1000^{\circ} \mathrm{C}$ e moída com acetato de butilglicol $(195,5 \mathrm{~nm})$

\begin{tabular}{|c|c|c|c|c|c|c|}
\hline $\begin{array}{c}\text { Ensaios de aceleração } \\
\text { reacional }\end{array}$ & PV 0 & $\begin{array}{c}\text { PV 1 } \\
\text { (CM) }\end{array}$ & $\begin{array}{c}\text { PV 2 } \\
\text { (CM) }\end{array}$ & $\begin{array}{c}\text { PV 3 } \\
\text { (CM) }\end{array}$ & $\begin{array}{c}\text { PV 4 } \\
\text { (CM) }\end{array}$ & $\begin{array}{c}\text { PV 5 } \\
\text { (CM) }\end{array}$ \\
\hline Verniz DX 0904 como fornecido & 100,00 & 100,00 & 100,00 & 100,00 & 100,00 & 100,00 \\
\hline $\begin{array}{c}\text { Endurecedor DX 194 como } \\
\text { fornecido }\end{array}$ & 20,00 & 20,00 & 20,00 & 20,00 & 20,00 & 20,00 \\
\hline Acetato de butilglicol & 10,12 & 9,67 & 9,23 & 8,33 & 6,55 & 2,98 \\
\hline $\begin{array}{c}\text { Dispersão de vermiculita (195,5 } \\
\text { nm) - concentração de 21,88\% }\end{array}$ & 0,00 & 0,57 & 1,14 & 2,29 & 4,57 & 9,14 \\
\hline $\begin{array}{c}\text { Concentração de vermiculita } \\
\text { (g/120g verniz+endurecedor) }\end{array}$ & 0,00 & 0,125 & 0,25 & 0,50 & 1,00 & 2,00 \\
\hline
\end{tabular}

CM - com tratamento térmico em mufla

Fonte: O Autor

Os ensaios de aceleração reacional apresentados na Tabela 10 foram preparados com vermiculita processada $(170,9 \mathrm{~nm})$ com tratamento térmico a $1000^{\circ} \mathrm{C}$ em mufla.

Tabela 10 - Massas $(\mathrm{g})$ utilizadas para o preparo das amostras para ensaio de aceleração reacional da vermiculita processada com tratamento térmico em mufla e moída com acetato de butilglicol $(170,9$ $\mathrm{nm})$

\begin{tabular}{|c|c|c|c|c|c|c|}
\hline $\begin{array}{c}\text { Ensaios de aceleração } \\
\text { reacional }\end{array}$ & PV 0 & $\begin{array}{c}\text { PV 6 } \\
\text { (CM) }\end{array}$ & $\begin{array}{c}\text { PV 7 } \\
\text { (CM) }\end{array}$ & $\begin{array}{c}\text { PV 8 } \\
\text { (CM) }\end{array}$ & $\begin{array}{c}\text { PV 9 } \\
\text { (CM) }\end{array}$ & $\begin{array}{c}\text { PV 10 } \\
\text { (CM) }\end{array}$ \\
\hline Verniz DX 0904 como fornecido & 100,00 & 100,00 & 100,00 & 100,00 & 100,00 & 100,00 \\
\hline $\begin{array}{c}\text { Endurecedor DX 194 como } \\
\text { fornecido }\end{array}$ & 20,00 & 20,00 & 20,00 & 20,00 & 20,00 & 20,00 \\
\hline Acetato de butilglicol & 10,12 & 9,69 & 9,27 & 8,41 & 6,70 & 3,29 \\
\hline $\begin{array}{c}\text { Dispersão de vermiculita (170,9 } \\
\text { nm) - concentração de 22,64 \% }\end{array}$ & 0,00 & 0,55 & 1,10 & 2,21 & 4,41 & 8,83 \\
\hline $\begin{array}{c}\text { Concentração de vermiculita } \\
\text { (g/120g verniz+endurecedor) }\end{array}$ & 0,00 & 0,125 & 0,25 & 0,50 & 1,00 & 2,00 \\
\hline
\end{tabular}

CM - com tratamento térmico em mufla

Fonte: O Autor 
A função de um catalisador é acelerar a velocidade de obtenção de um determinado produto advindo de uma reação química presente no processo reacional. Por se tratar de um verniz de dois componentes pode-se perceber a ação catalítica, avaliando o aumento da viscosidade do sistema (FAZENDA et al., 2009). E esta elevação na viscosidade é devida à elevação da massa molar dos constituintes reacionais; a reação entre o endurecedor contendo grupos $\mathrm{R}-\mathrm{N}=\mathrm{C}=\mathrm{O}$ e a resina base do verniz contendo estruturas $\mathrm{R}^{\prime}-\mathrm{OH}$; gera uma reação de adição, o avanço desta reação cria estruturas com elevada massa molar e consequentemente maior viscosidade.

Assim, para a avaliação do efeito da adição de vermiculita processada na aceleração da reação, o parâmetro avaliado foi a viscosidade da mistura. A viscosidade foi determinada por meio do viscosímetro Copo Ford Número 4 pela facilidade de utilização e por ser esse viscosímetro muito utilizado no mercado para determinar as viscosidades de tintas e vernizes.

Na Figura 7 é mostrado o viscosímetro Copo Ford número 4 utilizado para determinação de viscosidade usando a norma ASTM D 1200.

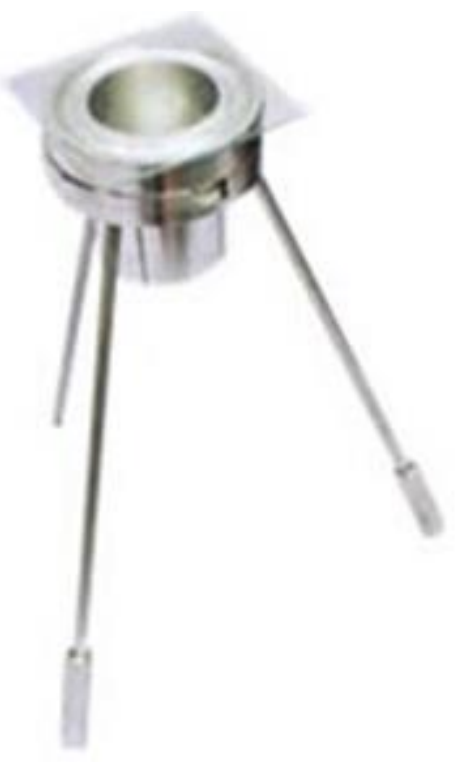

Figura 7 - Viscosímetro Copo Ford 4, equipamento utilizado para determinação da viscosidade Fonte: Adaptado de http://www.isolabor.com.br/fabricacao.html ; em 10/03/2017 
O princípio de funcionamento deste viscosímetro é baseado no tempo de escoamento de um fluído contido em seu interior. Na parte inferior deste copo existe um orifício por onde o fluído nele contido escoa. O tempo de escoamento é determinado em segundos sendo assim, quanto maior a viscosidade do fluído maior será o tempo de retenção deste fluído no viscosímetro. Este princípio está de acordo com o propósito de verificação da atividade da vermiculita sobre a reação entre o endurecedor e a resina base presente no verniz.

\subsubsection{Caracterização dos filmes aplicados quanto à dureza}

A dureza em filmes de tintas ou vernizes evidencia que o filme adquiriu determinados níveis internos de rigidez.

Os filmes de vernizes uretânicos de dois componentes - verniz base com adição de endurecedor - adquirem níveis de dureza em função das múltiplas ligações químicas que ocorrem entre as resinas do verniz e do endurecedor.

Os filmes que se formam por reação química podem ter essa reação acelerada com a adição de outras substâncias na composição do verniz (FAZENDA et al., 2009).

O ensaio de dureza foi efetuado segundo a norma ASTM D4366-94 no equipamento de dureza König; na Figura 8 é mostrado o tipo de equipamento de pêndulo para determinação de dureza.

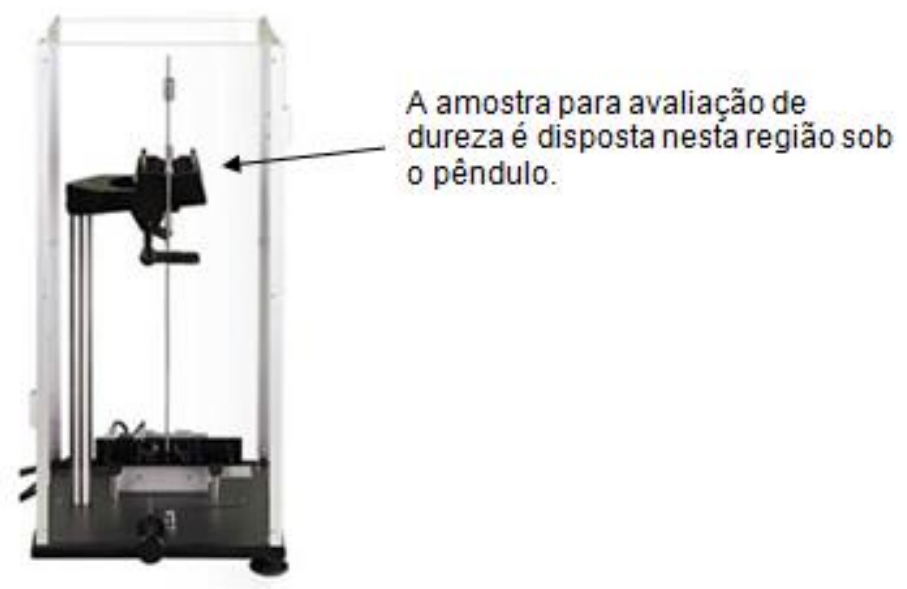

Figura 8 - Equipamento de determinação de dureza

Fonte : Adaptado de https://br.all.biz/durometro-de-pendulo-g84573 ; capturado em 10 de julho de 2017 
Duas amostras de vermiculita processadas em acetato de butilglicol, de tamanhos médios de 170,9 nm e 195,5 nm, foram utilizadas na preparação dos filmes que foram aplicados sobre placas de vidro planos e transparentes para analise em relação ao comportamento de dureza. A espessura média dos filmes aplicados variou entre 35 a 45 micrômetros. Com essas vermiculitas processadas foram preparados filmes com três porcentagens de vermiculita sobre $100 \mathrm{~g}$ de matéria nãovolátil do sistema verniz-endurecedor: $0,87 \% ; 1,74 \%$ e 3,48 \%. Este valor inicial de $0,87 \%$ foi definido a partir da analise de resultados preliminares que levaram em conta um conjunto de propriedades tecnologicamente viáveis e aceitas para o segmento dos vernizes automotivos.

A dureza foi determinada em cada uma dessas formulações e também em uma formulação sem adição de vermiculita (que serviu de referência) após envelhecimento de 24 horas, 48 horas, 144 horas e 168 horas à temperatura ambiente (temperatura média de $25^{\circ} \mathrm{C}$ ), em ambiente de umidade controlada (umidade relativa do ar entre $60 \%$ e $80 \%$ ).

\subsubsection{Investigação de propriedade de barreira da vermiculita processada}

Para avaliar um eventual efeito de barreira da vermiculita processada foi utilizado um ensaio de impedância eletroquímica. A identificação de propriedade de barreira formada pelas partículas de vermiculita processada pode ser uma opção para indicação de usos desta carga em sistemas anticorrosivos ou em outros sistemas onde as propriedades de barreira sejam desejadas..

Para a avaliação do comportamento de barreira das partículas de vermiculita processada, foi escolhida uma resina de dispersão uretânica ao invés de um poliuretano de dois componentes pelo motivo que a dispersão uretânica forma filme ausente de reticulação entre as moléculas de resina e consequentemente filme com tendência de maior permeabilidade.

Vermiculita processada com tamanho médio de partícula de $479 \mathrm{~nm}$ (processada em meio aquoso) foi incorporada na dispersão de resina uretânica (PU) 
nas proporções apresentadas na Tabela 11. Os vernizes foram aplicados com pistola de pintura convencional tipo "spray", sobre chapas de aço carbono 1020 da Empresa Aquarela de Acabamentos de Superfícies Ltda. , dimensões de $100 \times 200$ $\mathrm{mm}$, tratadas com fosfato de zinco. Na Figura 9 é mostrada uma pistola convencional tipo "spray". As amostras preparadas conforme a Tabela 11 foram inseridas no reservatório superior da pistola e aplicadas conforme procedimento técnico operacional. Para aplicação, a pistola foi conectada a um sistema de ar comprimido a uma pressão média de 60 libras.

Tabela 11 - Preparo das amostras para análise das propriedades eletroquímicas dos filmes aplicados sobre chapa de aço carbono 1020 com fosfato de zinco

\begin{tabular}{|c|c|c|c|}
\hline $\begin{array}{c}\text { Substrato: chapa de } \\
\text { aço carbono 1020 } \\
\text { com fosfato de zinco }\end{array}$ & $\begin{array}{c}\text { Codificação das } \\
\text { amostras }\end{array}$ & $\begin{array}{c}\text { Quantidade da } \\
\text { dispersão uretânica } \\
\text { em g (parte não } \\
\text { volátil) }\end{array}$ & $\begin{array}{c}\text { Quantidade de } \\
\text { vermiculita } \\
\text { processada em g } \\
\text { (parte não volátil) }\end{array}$ \\
\hline $\begin{array}{c}\text { Chapa de aço carbono } \\
1020 \text { com fosfato de zinco }\end{array}$ & MB & - - - & - - \\
\hline \multirow{2}{*}{$\begin{array}{c}\text { Sistemas com revestimento } \\
\text { de resina aplicados sobre } \\
\text { chapa de aço carbono 1020 } \\
\text { com fosfato de zinco }\end{array}$} & PU / VE 6\% & 100 & 0 \\
\cline { 2 - 4 } & PU / VE 12\% & 100 & 5 \\
\cline { 2 - 4 } & PU / VE 24 \% & 100 & 24 \\
\hline
\end{tabular}

Legendas : $\mathrm{U}=$ Uretano; $\mathrm{VE}=$ vermiculita; $\mathrm{MB}=$ Metal Base Fonte: O Autor

Para adequação ao equipamento de ensaio eletroquímico as respectivas chapas de aço foram cortadas por guilhotina. 
Figura 9 - Pistola de aplicação tipo "spray

Fonte: http://www.azevedotintas.com.br/steula-pistola-de-pintura-alta-producao-bc-7517-hvlp.html capturado em 29/06/2017

As chapas aplicadas com dispersão uretânica pura e com as incorporações das cargas minerais foram mantidas em temperatura ambiente, entre $25^{\circ} \mathrm{C}$ e $32^{\circ} \mathrm{C}$, por 72 h, com livre circulação de ar e umidade relativa do ar entre 60 \% e 80 \%.

As espessuras médias das películas secas ficaram em torno de $15 \pm 3$ micrômetros determinados por um medidor de camada com sonda para materiais ferrosos e não ferrosos; equipamento MOD, CM8829 fabricante Medtec.

A análise do desempenho destas combinações foram avaliadas por Espectroscopia de Impedância Eletroquímica e para avaliar a proteção por barreira foram realizados ensaios eletroquímicos de impedância pelo processo de imersão em solução de $\mathrm{NaCl}$ 0,1 M; com duração de uma hora para cada sistema avaliado.

Os ensaios eletroquímicos foram realizados utilizando um sistema com três eletrodos constando de um micro eletrodo de referência de $\mathrm{Ag} / \mathrm{AgCl}(\mathrm{KCl}$ sat.) e de uma folha de Pt como contra eletrodo. Estes ensaios foram realizados no potencial de circuito aberto (PCA) utilizando um potenciostato (AUTOLAB 70896) acoplado a um analisador de resposta em frequência (FRA2). Com diagramas obtidos após 30 min de estabilização do PCA, em meios de $\mathrm{NaCl} 0,1 \mathrm{M}$ com intervalo de frequência de $10^{4} \mathrm{~Hz}$ a $10^{-2} \mathrm{~Hz}$; aquisição de 10 pontos por década logarítmica, e amplitude de 
perturbação de $10 \mathrm{mV}$ (rms). Para aquisição dos dados foi utilizado o programa NOVA ${ }^{\circledR}$.

Depois de processadas, as bases aquosas e as bases não aquosas, foram combinadas aos sistemas em estudo nesta Tese. A seleção para as combinações levou em conta exclusivamente o critério de compatibilidade entre os solventes das bases e os meios escolhidos para estudo. 


\section{RESULTADOS E DISCUSSÃO}

\subsection{Resultados - Considerações preliminares}

\subsubsection{Objetivos da Tese}

A presente Tese tem como objetivo expor um estudo para utilização da vermiculita processada como carga ativa em verniz uretânico; introduzindo assim, uma potencial inovação à área de materiais compósitos.

Esta inovação baseia-se na identificação de uma aplicação ou aplicações para o mineral vermiculita, obtido na forma de um pó a partir de processamento por moagem de vermiculita piroexpandida comercial.

As discussões referentes aos ensaios e aos resultados dos mesmos obedece a uma ordem que parte do processamento e se estende às aplicações .

As discussões serão feitas diretamente após a apresentação de cada conjunto de resultados experimentais.

\subsection{Caracterização da vermiculita}

5.2.1 Análise química (por fluorescência de raios $X$ )

$\mathrm{Na}$ Tabela 12 são apresentados os resultados da análise química da vermiculita piroexpandida de partida.

A composição química foi consistente com a composição de vermiculitas brasileiras de Brumado e de Sanclerlândia, apresentadas na Tabela 2. 
Tabela 12 - Análise química por fluorescência de raios $X$ da vermiculita piroexpandida que foi a base dos materiais produzidos nesta Tese

\begin{tabular}{|c|c|c|c|}
\hline Óxido & $\%$ & Óxido & $\%$ \\
\hline $\mathrm{SiO}_{2}$ & 40,50 & $\mathrm{Na}_{2} \mathrm{O}$ & $<0,10$ \\
\hline $\mathrm{Al}_{2} \mathrm{O}_{3}$ & 12,20 & $\mathrm{~K}_{2} \mathrm{O}$ & 0,99 \\
\hline $\mathrm{Fe}_{2} \mathrm{O}_{3}$ & 8,79 & $\mathrm{TiO}_{2}$ & 1,16 \\
\hline $\mathrm{MnO}$ & $<0,10$ & $\mathrm{P}_{2} \mathrm{O}_{5}$ & $<0,10$ \\
\hline $\mathrm{MgO}$ & 23,10 & P.F. & 11,00 \\
\hline $\mathrm{CaO}$ & 0,92 & TOTAL & $\mathbf{9 8 , 8 3}$ \\
\hline
\end{tabular}

Fonte: Análise realizada no LCT-PMI-EPUSP para este e outros trabalhos realizados com vermiculita no LPSS-PMT-EPUSP

\subsubsection{Difração de raios $X$}

Nas Figuras 10 -13 são apresentados os resultados de difração de raios $X$ relativos as amostras de vermiculita estudadas nesta Tese.

Na Figura 10 é mostrada a curva de DRX de uma amostra de um concentrado comercial de vermiculita da região de São Luís dos Montes Belos, a mesma região do material que foi estudado nesta Tese, "in natura", ainda sem piroexpansão. A fase amplamente majoritária é a vermiculita. Como fase acessória, em pequena quantidade, foi identificado ao menos um outro filossilicato 2:1 (uma mica ${ }^{1}$ ou uma hidrobiotita ${ }^{2}$ ).

Na Figura 11 é mostrada a curva de DRX da amostra comercial de vermiculita piroexpandida da mesma região de São Luís dos Montes Belos. Para a obtenção dessa curva, partículas do material piroexpandido - constituído de partículas irregulares de dimensões milimétricas - tiveram que ser moídas (a difração de raios $X$ pelo método do pó necessita de um pó para ser realizada). Essas partículas então foram moídas, e o que foi analisado foi um pó passante em malha ABNT\#180.

\footnotetext{
${ }^{1}$ MICA : refere-se a um grupo de filossilicatos 2:1 com cátions não-trocáveis no espaço interlamelar (geralmente potássio), contendo pouca ou nenhuma água intercalada (KLEIN;HURLBUT, 1977).

${ }^{2}$ HIDROBIOTITA : interestratificação regular de biotita (que é uma mica) e de vermiculita. A sua fórmula é: $\mathrm{K}\left(\mathrm{Mg}_{\mathrm{Fe}} \mathrm{Fe}^{2+}\right)_{6}(\mathrm{Si}, \mathrm{Al})_{8} \mathrm{O}_{20}(\mathrm{OH})_{4} \cdot \mathrm{nH}_{2} \mathrm{O}$ (BRINDLEY; ZALBA; BETHKE, 1983).
} 


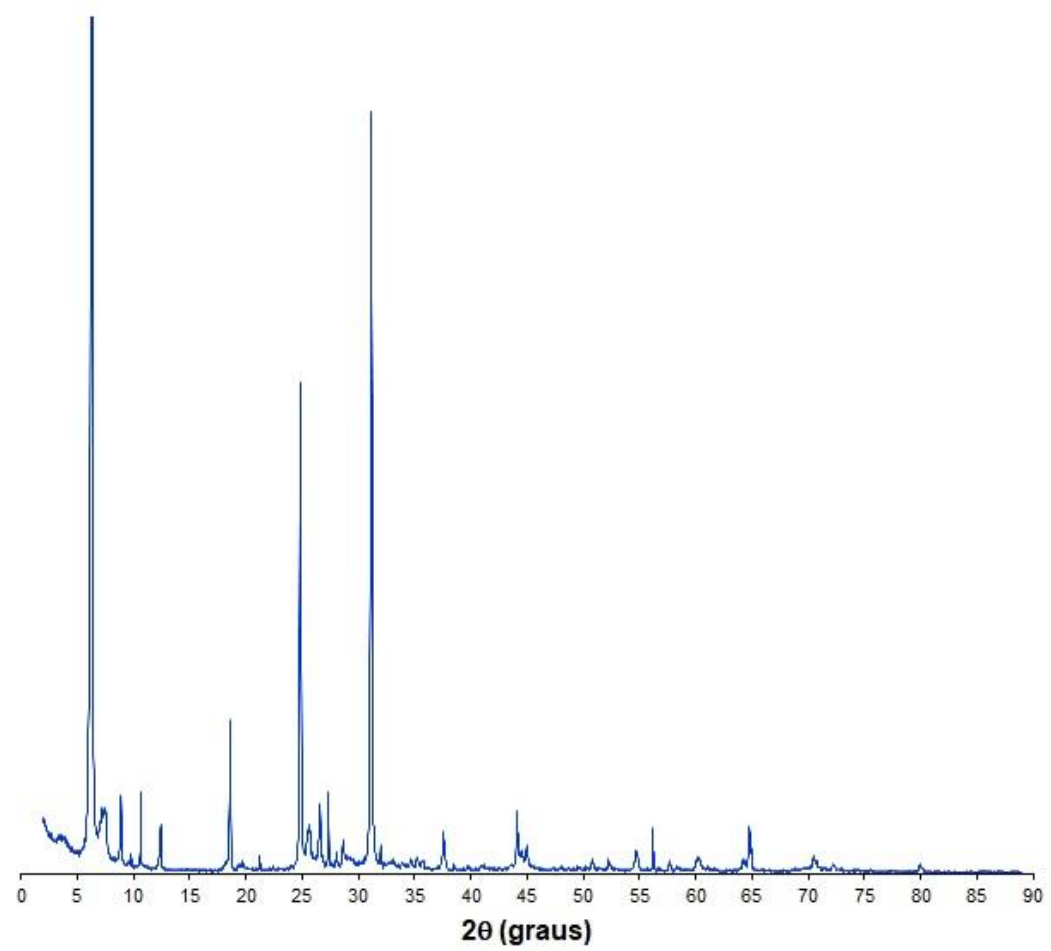

Figura 10 - Curva de difração de raios X da vermiculita de São Luís de Montes Belos, "in natura" (não piroexpandida)

Fonte: LPSS - PMT - EPUSP

Foi a partir desse material piroexpandido que foram feitos os processamentos de moagem estudados nesta Tese. Observou-se que o processo de piroexpansão não foi capaz de desidroxilar completamente a vermiculita, uma vez que as principais reflexões do mineral ainda estão presentes. Segundo a curva de DRX, a fase majoritária ainda é a vermiculita; ainda são observadas reflexões da outra fase 2:1 (hidrobiotita ou mica) e já são observadas reflexões da enstatita,

A enstatita é um produto da alteração térmica da vermiculita, causada pelo processo de piroexpansão. Enstatita é o nome dado ao mineral $\mathrm{MgSiO}_{3}$. Esse mineral é o extremo magnesiano da série enstatita $\left(\mathrm{MgSiO}_{3}\right)$ - ferrossilita $\left(\mathrm{FeSiO}_{3}\right)$. Podem existir composições intermediárias (por ex.: $(\mathrm{Mg}, \mathrm{Fe}) \mathrm{SiO}_{3}$ que é chamado ortopiroxênio) e soluções sólidas - quando esse é o caso, as composições são apresentadas na forma de proporções relativas das fases enstatita (En) e ferrossilita (Fs), por ex.: $E_{80} \mathrm{Fs}_{20}$ (KLEIN; DUTROW, 2008; DYAR et al., 2008). Essas composições intermediárias são muito difíceis de serem distinguidas por DRX. No caso da vermiculita estudada nesta Tese, é muito provável, dada a sua composição 
química, que o que efetivamente exista seja uma dessas composições intermediárias contendo magnésio e ferro.

É importante notar que as intensidades das reflexões diminuíram bastante, indicativo de que, mesmo não tendo ocorrido a desidroxilação total da vermiculita no processo de piroexpansão, esse processo já causou uma certa diminuição na ordem estrutural na vermiculita.

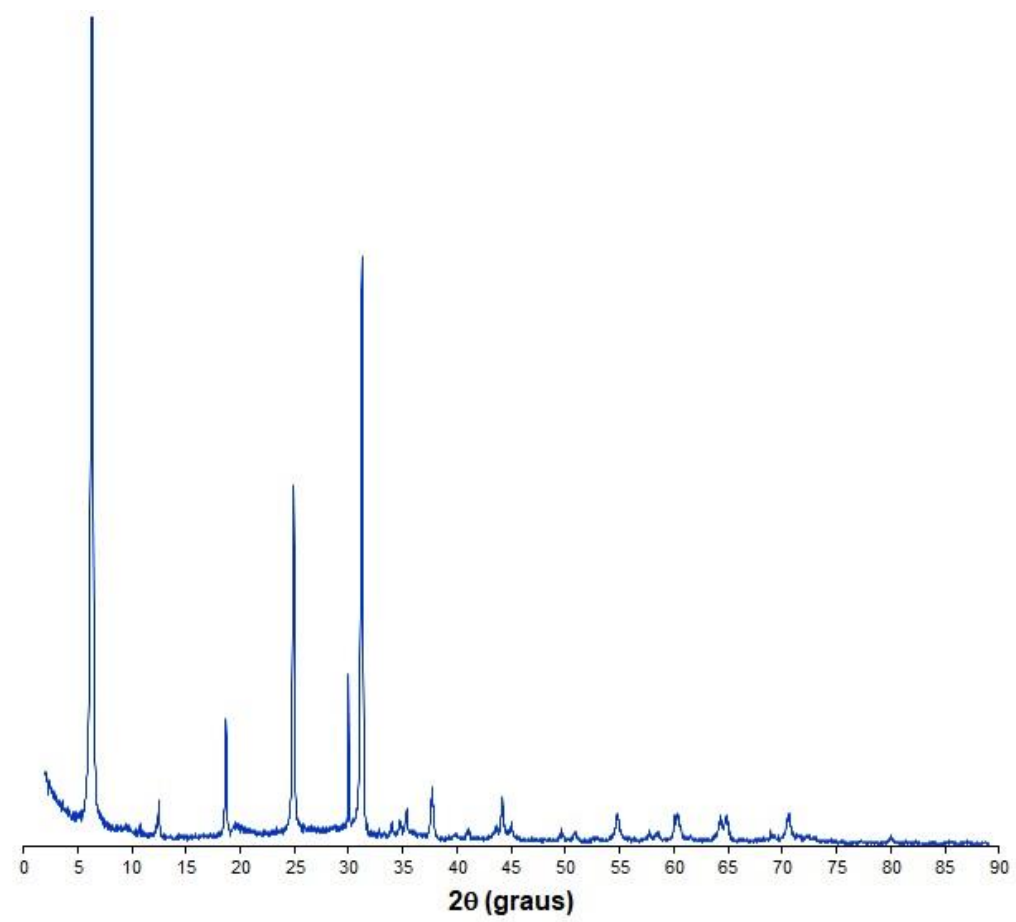

Figura 11 - Curva de difração de raios X da vermiculita comercial de São Luís de Montes Belos, piroexpandida. O máximo de escala de intensidade desta curva de DRX é igual à $0,5 X$ do máximo da curva de DRX da Figura 10

Fonte: LPSS - PMT - EPUSP

Na Figura 12 são mostradas as curvas de DRX de duas amostras de vermiculita piroexpandida processadas por moagem em meio aquoso por $2 \mathrm{~h}$ e por 4h (respectivamente amostras VP245 e VP246, ref. Tabelas 3, 4). As curvas de DRX dessas duas amostras são muito similares entre si, e apresentam diferenças significativas em relação à curva de $D R X$ do material piroexpandido. As fases presentes são a vermiculita e a enstatita, mas as intensidades relativas das reflexões da vermiculita são muito menores do que as observadas na Figura 11, indicando que o processo de moagem acarreta grandes perdas de ordem estrutural na vermiculita - em especial, no empilhamento de camadas 2:1, conforme o mostra a diminuição 
de intensidade das reflexões (00l). Fica evidente, portanto, que o processamento por moagem em meio aquoso por até $4 \mathrm{~h}$, além de ser capaz de reduzir o tamanho médio de partículas das vermiculitas processadas, é capaz de alterar o empilhamento de camadas 2:1 da vermiculita piroexpandida, delaminando suas partículas, sem no entanto destruir totalmente a sua ordem estrutural, uma vez que as reflexões principais da vermiculita ainda estão presentes.

Na Figura 13 é mostrado a curva de DRX da vermiculita piroexpandida e adicionalmente calcinada por $3 \mathrm{~h}$ a $1000^{\circ} \mathrm{C}$. Esse processo de calcinação adicional a $1000^{\circ} \mathrm{C}$ desidroxila de forma praticamente completa a vermiculita, e as reflexões mais intensas observadas são as da enstatita. Também é provável a presença de uma fase amorfa, indicada pela presença de um "halo" com máximo em torno de 20ํ⒇, que é característico de silicatos amorfos (MUSIĆ et al., 2011).

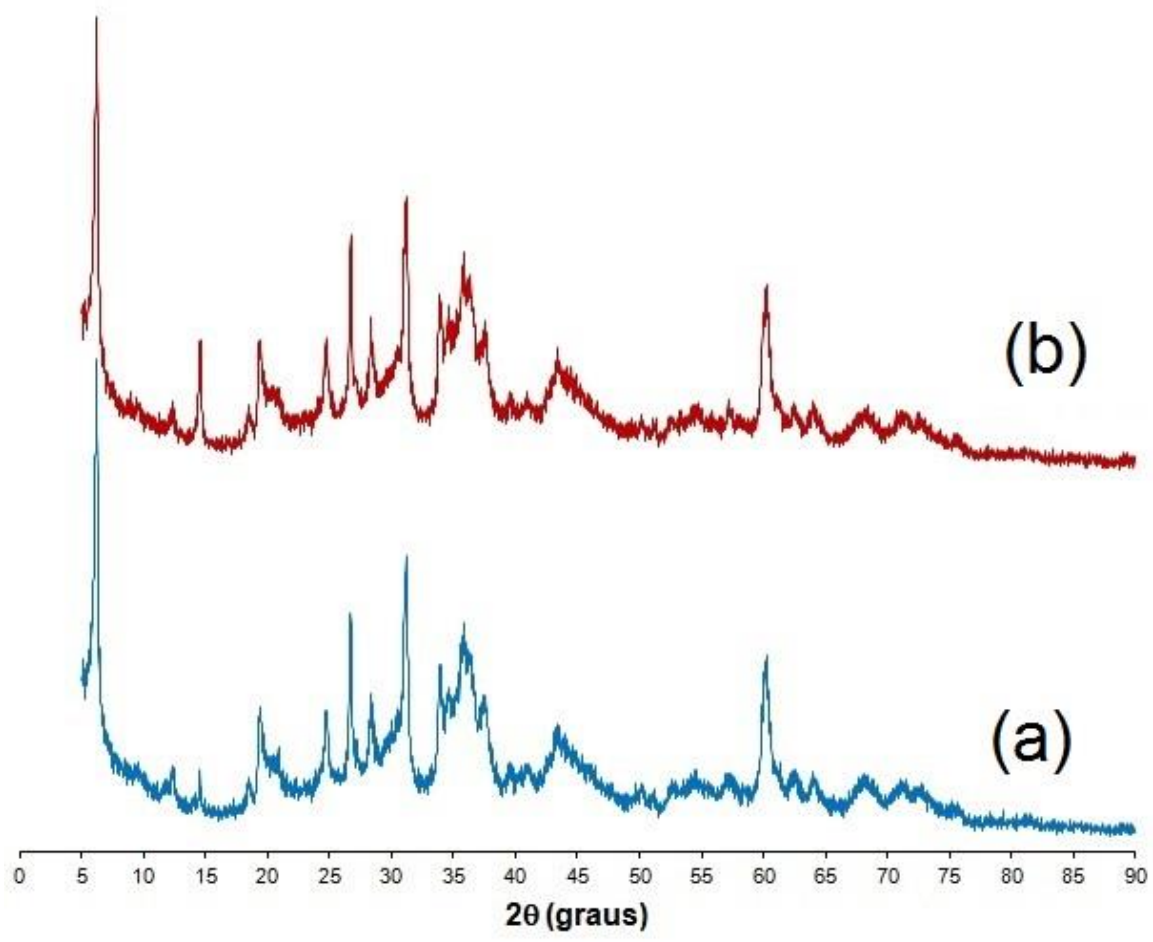

Figura 12 - Curvas de difração de raios $X$ da vermiculita piroexpandida processada por moagem em meio aquoso (a) por $2 \mathrm{~h}$ e (b) por $4 \mathrm{~h}$. O máximo de escala de intensidade de cada uma das curvas de DRX é igual à $0,1 X$ do máximo da curva de DRX da Figura 10

Fonte: LPSS - PMT - EPUSP 


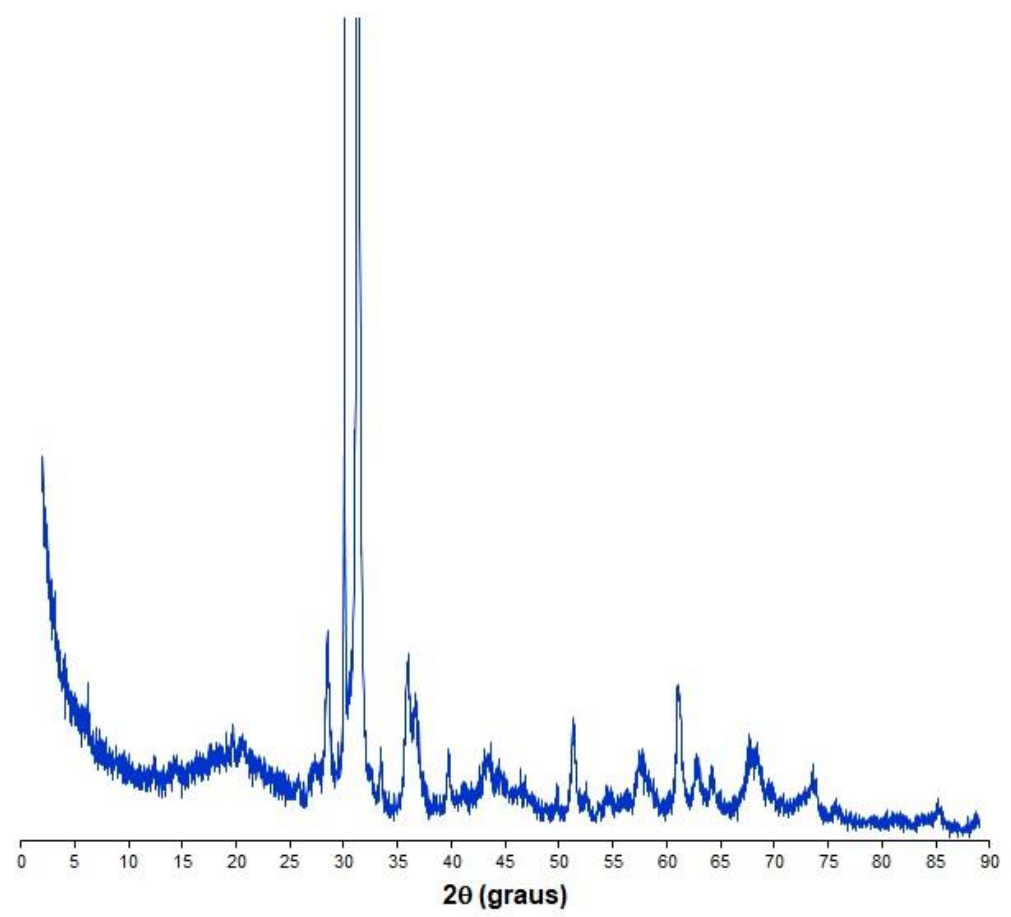

Figura 13 - Curva de difração de raios $X$ da vermiculita piroexpandida após calcinação adicional por $3 \mathrm{~h}$ a $1000^{\circ} \mathrm{C}$. O máximo de escala de intensidade desta curva de DRX é igual à $0,1 \mathrm{X}$ do máximo da curva de DRX da Figura 10 (o mesmo máximo de escala da Figura 12)

Fonte: LPSS - PMT - EPUSP

\subsubsection{Microscopia Eletrônica de Varredura (MEV)}

$\mathrm{Na}$ Figura 14 são mostradas as micrografias de partículas da vermiculita piroexpandida comercial que foi estudada nesta Tese. Elas mostram a morfologia típica do mineral expandido, e deixam claro que o processo de piroexpansão foi capaz de separar, em muito pontos, os empilhamentos de camadas 2:1 do argilomineral, o que poderia levar, em um processo de moagem, à produção de partículas muito finas (apenas como exemplo, o empilhamento de camadas 2:1 realçado no centro da Figura 14-c tem uma espessura estimada de $20 \mathrm{~nm}$ ).

Nas Figuras 15 e 16 são mostradas as micrografias das partículas obtidas a partir do processamento por moagem em água desmineralizada por $2 \mathrm{~h}$ (Figura 15) e por 4h (Figura 16). A microestrutura típica da vermiculita piroexpandida foi destruída nos dois tempos de processamento, e os dois materiais obtidos apresentaram a mesma morfologia: agregados, aparentemente formados por partículas lamelares muito finas fracamente ligadas entre si - os agregados lembravam flocos de pedacinhos de papel. 
Nas Figuras 17 e 18 são mostradas as micrografias das partículas obtidas a partir do processamento por moagem em butilglicol por $8 \mathrm{~h}$ (Figura 17) e por $12 \mathrm{~h}$ (Figura 18). A microestrutura típica da vermiculita piroexpandida também foi destruída nos dois tempos de processamento, tal como ocorre no processamento realizado em água desmineralizada. As partículas lamelares muito finas também foram observadas nos dois tempos de processamento (Figuras 17a e 18a). Os agregados de partículas, no entanto, apresentaram-se mais compactos do que aqueles observados no caso do processamento realizado em água. No nível atual das informações disponíveis nesta Tese, não se tem como explicar essa observação.

Uma conclusão parcial que poderia ser tirada foi de que com os dois processamentos, tanto no meio aquoso quanto no meio orgânico (butiliglicol), foi possível obter-se partículas lamelares muito finas a partir da vermiculita piroexpandida. 


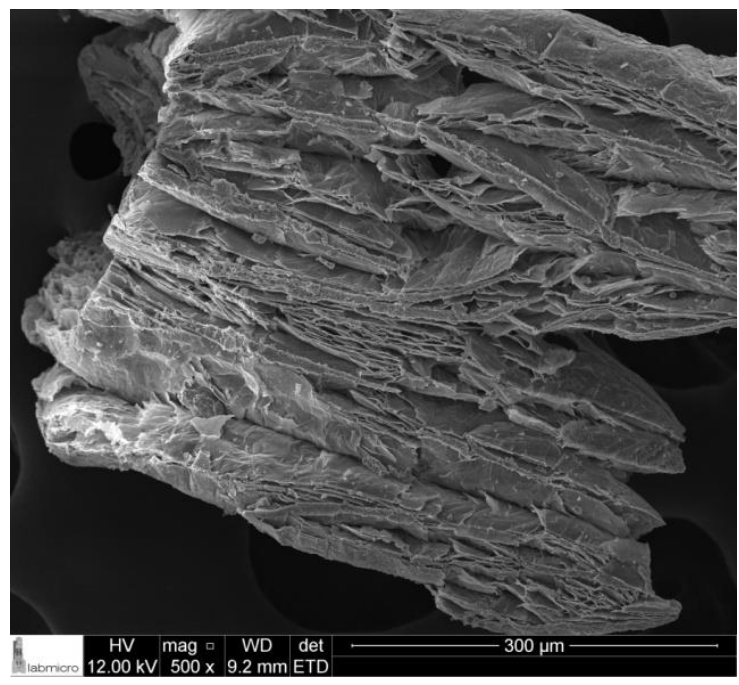

(a)

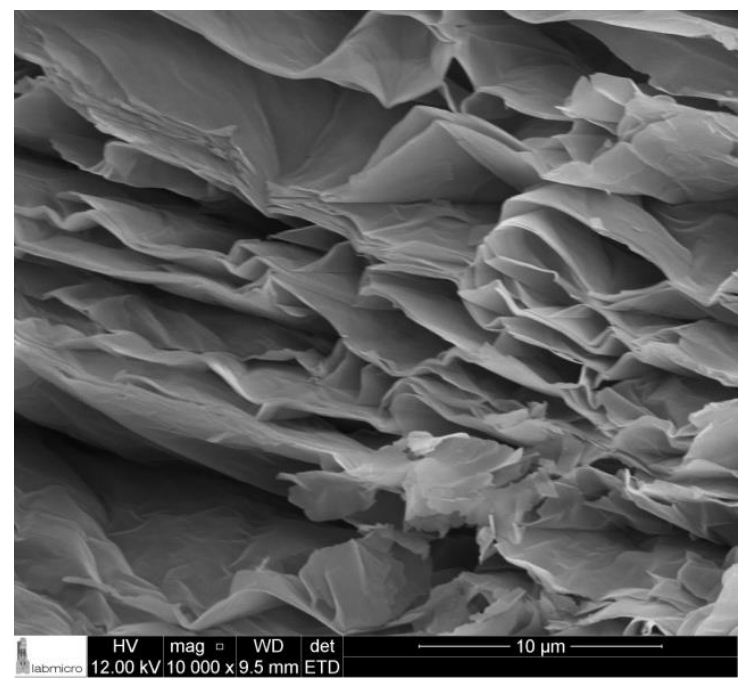

(b)

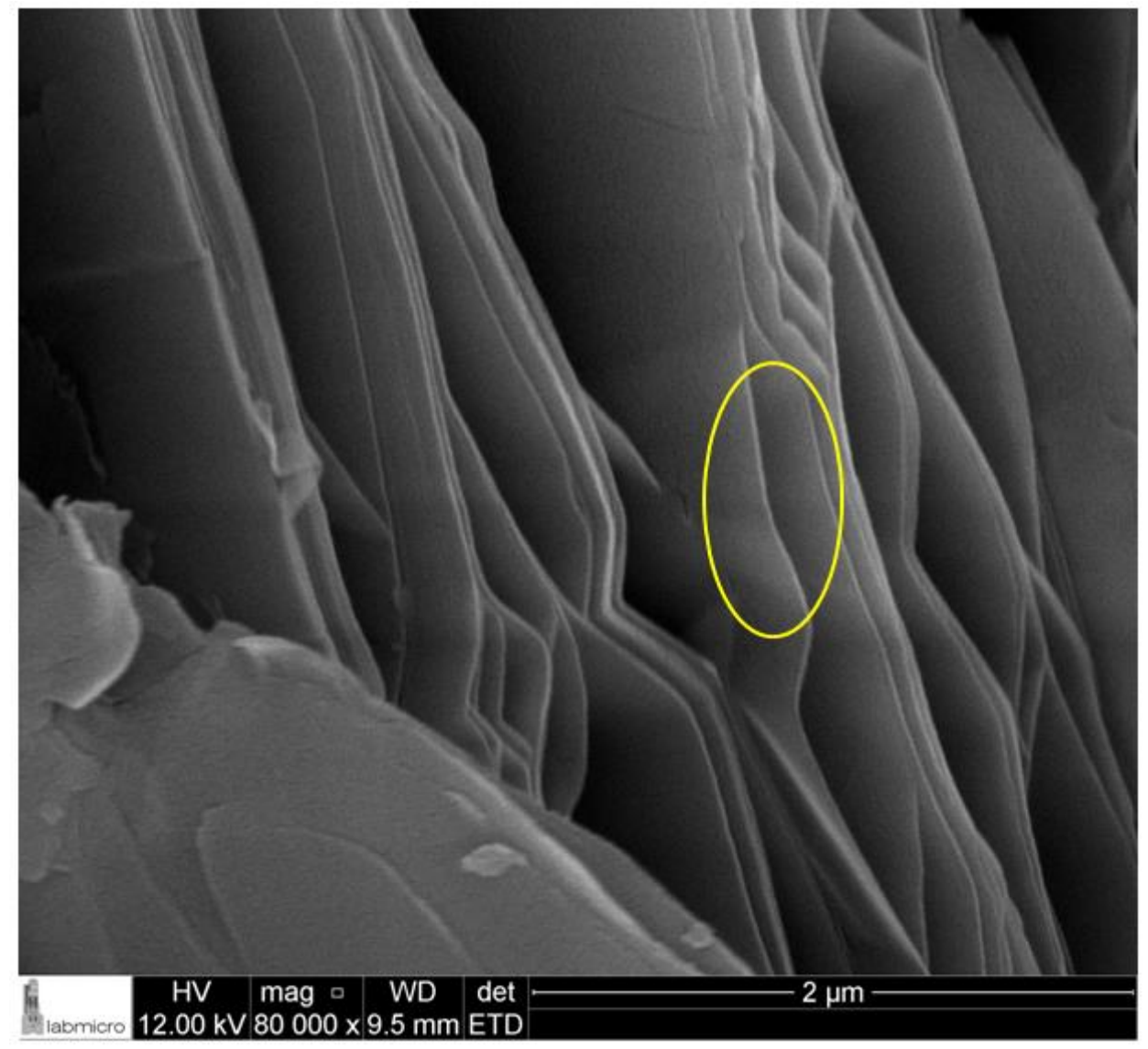

(c)

Figura 14 - Imagens de microscopia eletrônica de varredura (MEV) de: (a) uma partícula da vermiculita piroexpandida comercial empregada nesta Tese; (b)-(c) detalhes com maior ampliação de outras partículas examinadas na mesa preparação

Fonte: Labmicro - PMT - EPUSP, imagens obtidas para esta Tese e para outros trabalhos do LPSS empregando vermiculitas 

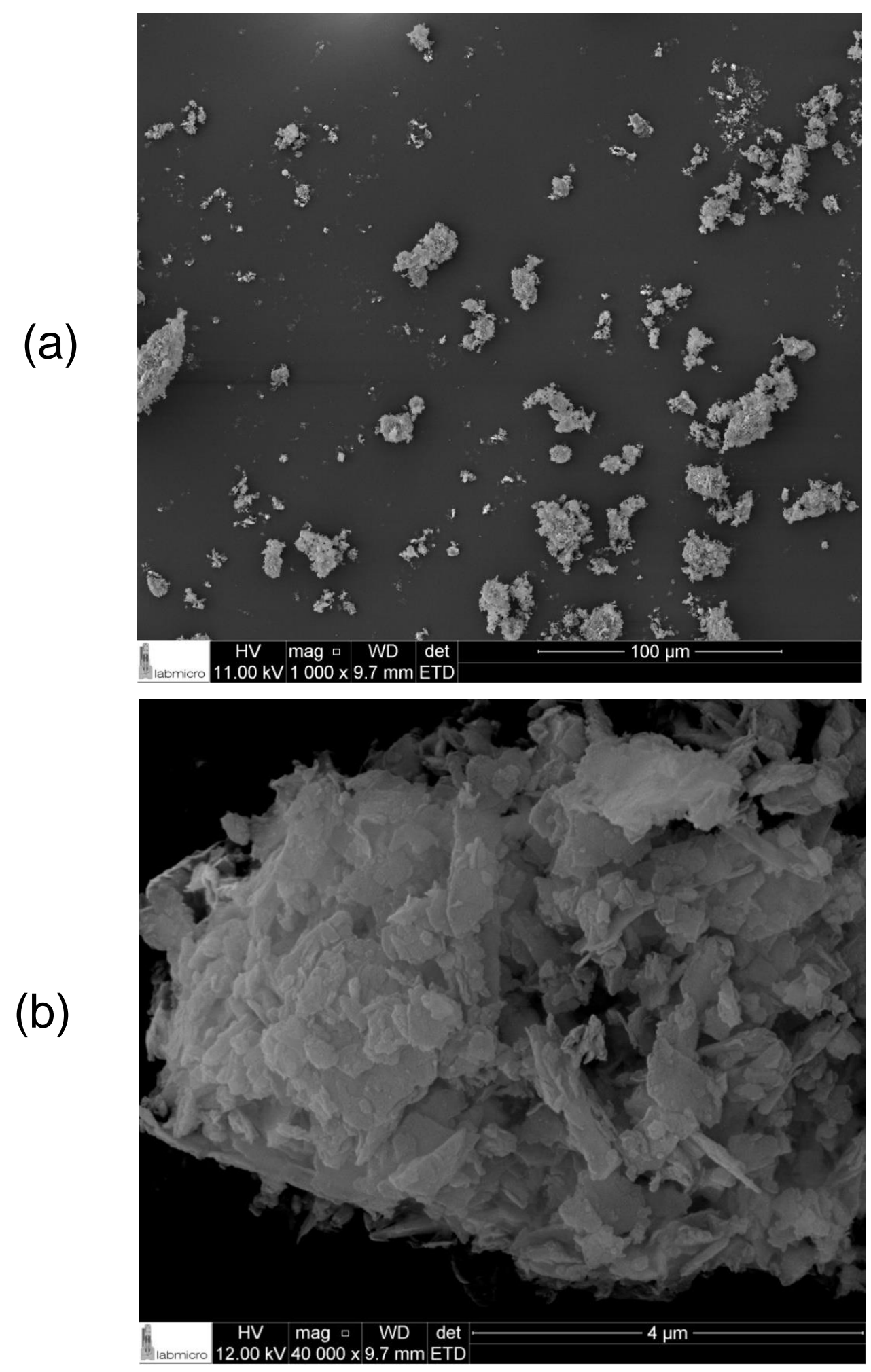

Figura 15 - Imagens de MEV de agregados de partículas obtidas a partir do processamento por moagem de vermiculita piroexpandida por $2 \mathrm{~h}$ em água desmineralizada: (a) imagem em campo geral, com pequeno aumento, para mostrar o aspecto geral do pó obtido após secagem e (b) agregado de partículas

Fonte: Labmicro - PMT - EPUSP, imagens obtidas para esta Tese e para outros trabalhos do LPSS empregando vermiculitas 
(a)

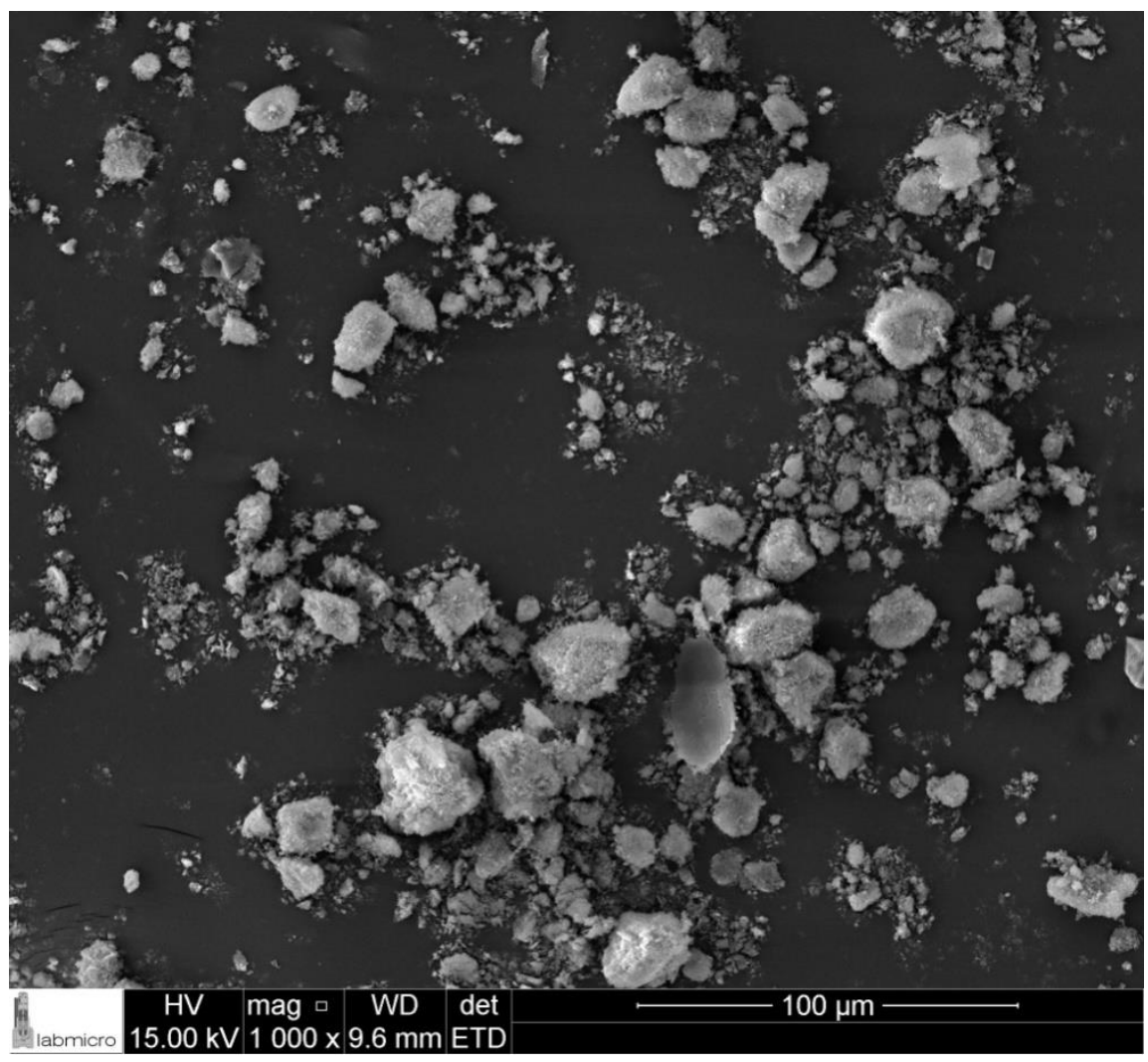

(b)

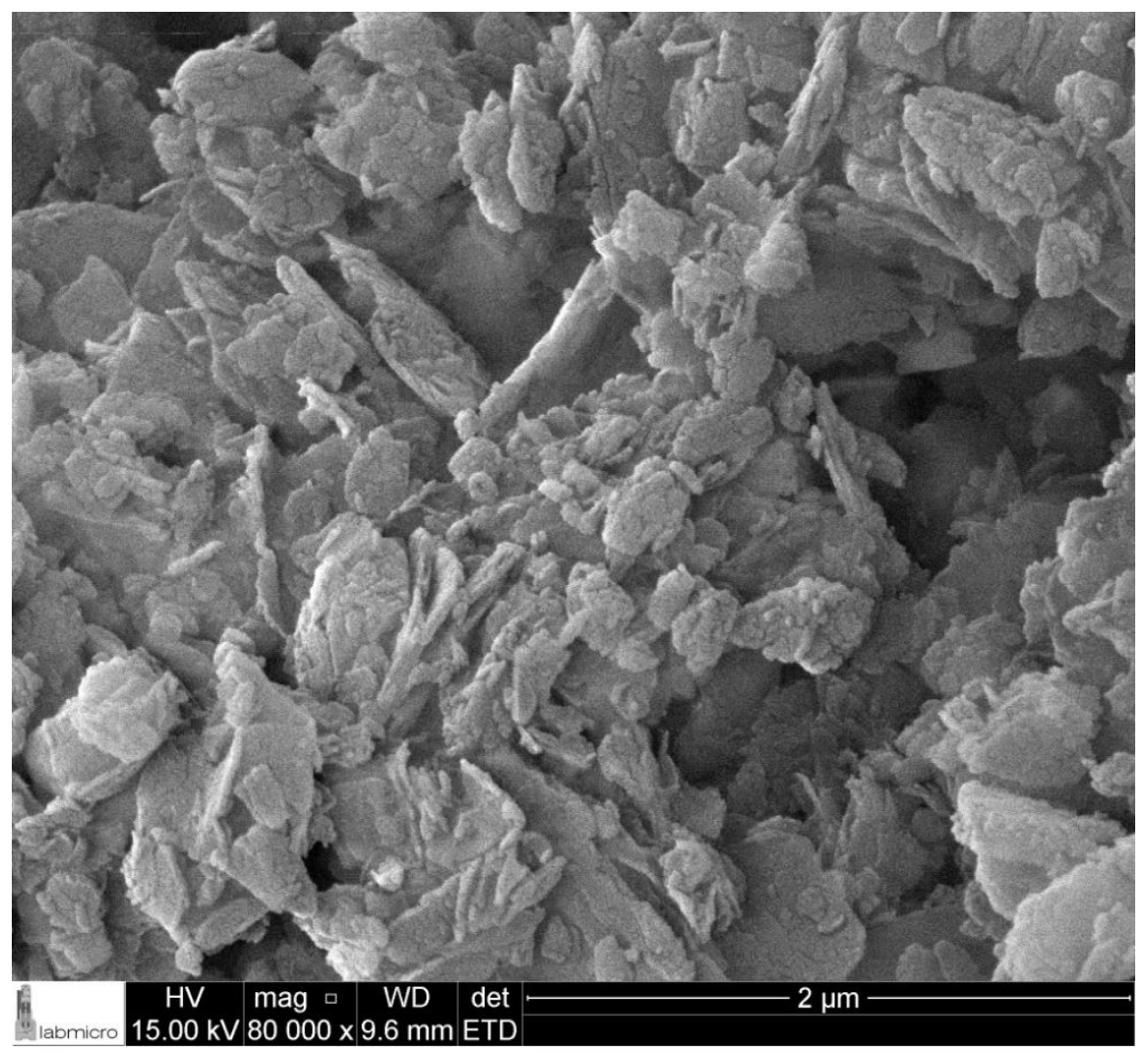

Figura 16- Imagens de MEV de agregados de partículas obtidas a partir do processamento por moagem de vermiculita piroexpandida por $4 \mathrm{~h}$ em água desmineralizada: (a) imagem em campo geral, com pequeno aumento, para mostrar o aspecto geral do pó obtido após secagem e (b) detalhe de agregado de partículas

Fonte: Labmicro - PMT - EPUSP, imagens obtidas para esta Tese e para outros trabalhos do LPSS empregando vermiculitas 
(a)
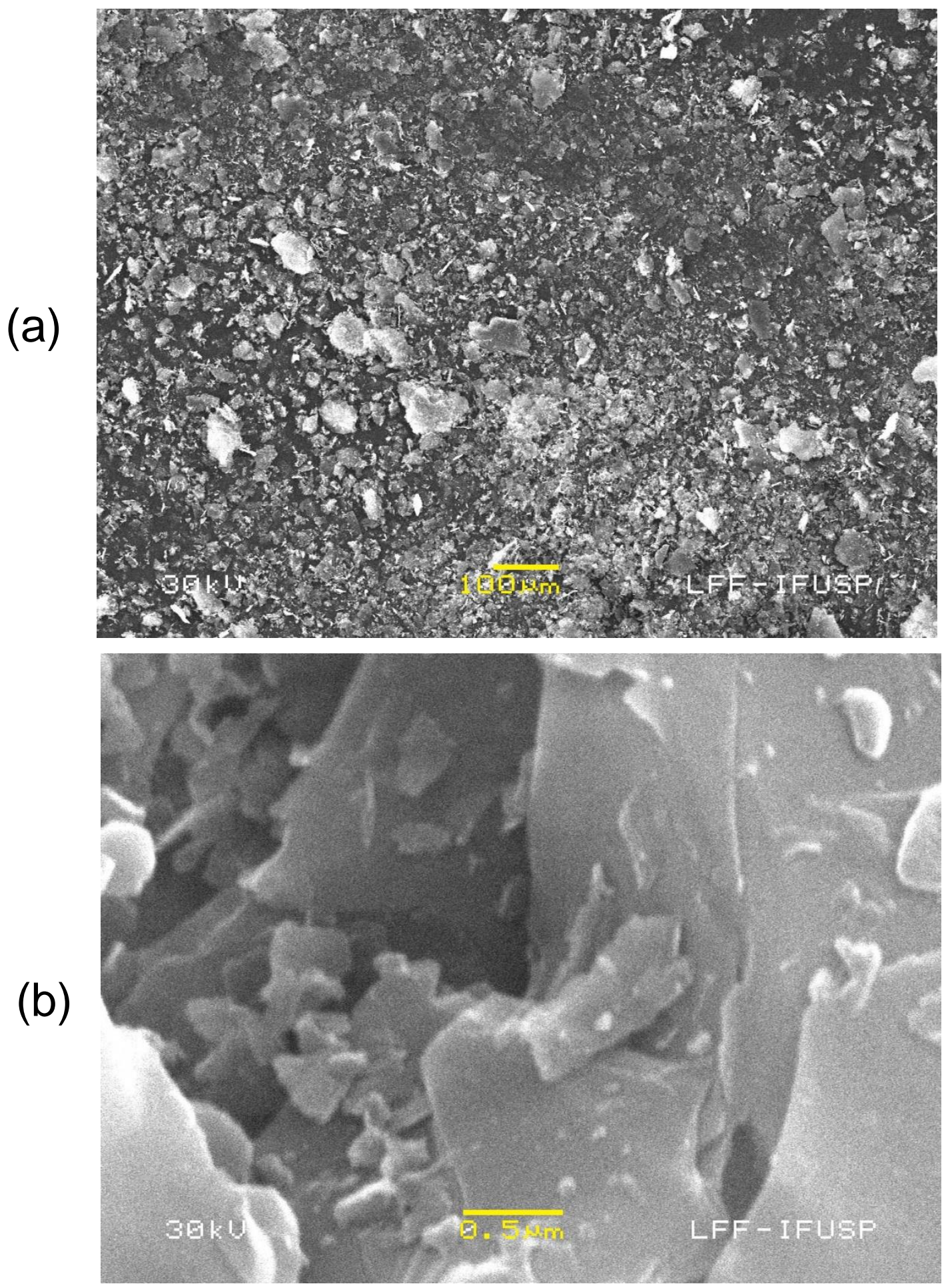

Figura 17 - Imagens de MEV de agregados de partículas obtidas a partir do processamento por moagem de vermiculita piroexpandida por $8 \mathrm{~h}$ em butilglicol: (a) imagem em campo geral, com pequeno aumento, para mostrar o aspecto geral do pó obtido após secagem e (b) detalhe de agregado de partículas Fonte: IF-USP 
(a)

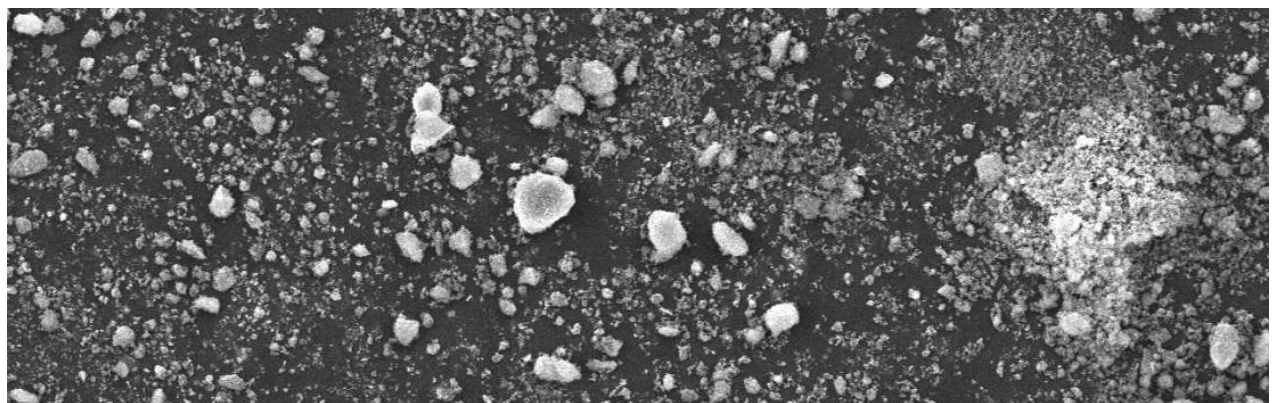

(b)
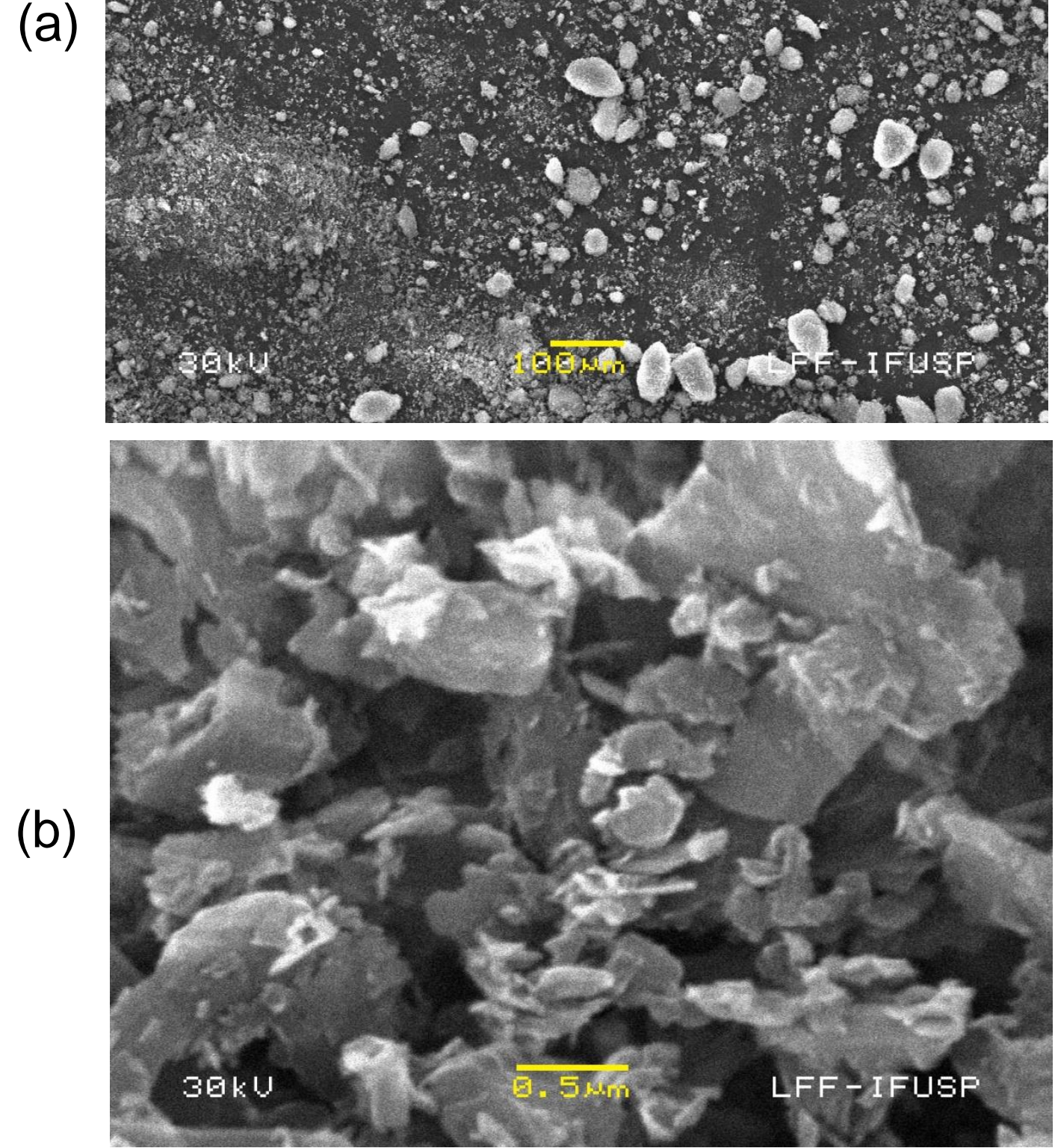

Figura 18 - Imagens de MEV de agregados de partículas obtidas a partir do processamento por moagem de vermiculita piroexpandida por $12 \mathrm{~h}$ em butilglicol: (a) imagem em campo geral, com pequeno aumento, para mostrar o aspecto geral do pó obtido após secagem e (b) detalhe de agregado de partículas

Fonte: IF-USP 
5.2.4 Determinação de tamanho de partículas por espalhamento de Luz- LASER

Para atender os objetivos da Tese, a vermiculita expandida comercial estudada foi encaminhada para moagem em duas condições distintas.

- Condição 1 : Amostra como recebida.

- Condição 2: Amostra tratada termicamente em forno mufla por $3 \mathrm{~h}$ a $1000^{\circ} \mathrm{C}$.

A Figura 19 mostra 0 aspecto da vermiculita expandida antes do processamento, e ilustra o aspecto das dispersões de partículas obtidas após processamento.
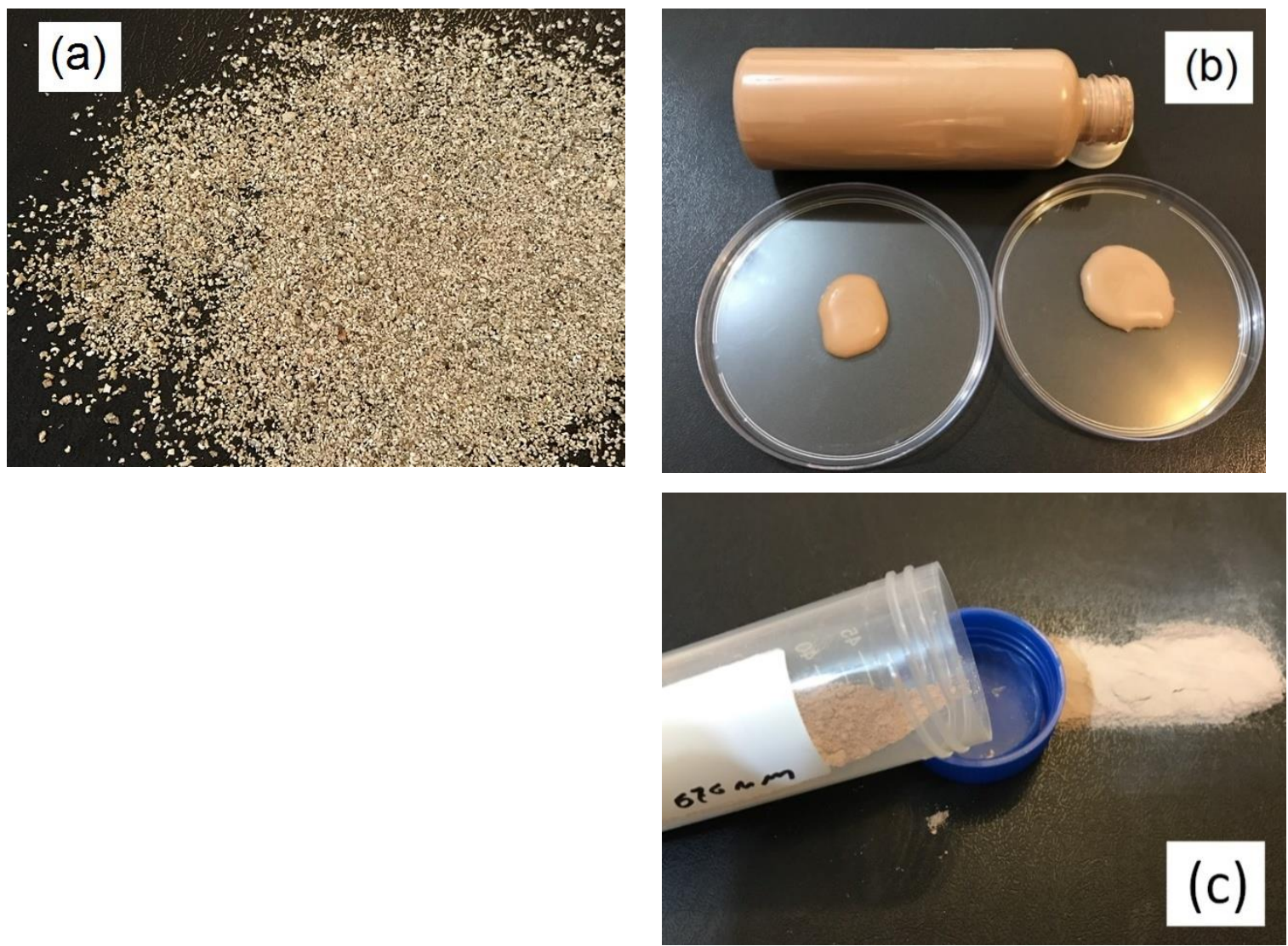

Figura 19 - (a) vermiculita piroexpandida comercial, antes do processamento de moagem; (b) Dispersão de vermiculita após processamento de moagem $(676 \mathrm{~nm})$;(c) pó de vermiculita $(676 \mathrm{~nm})$ seco e desagregado, obtido após processamento de moagem

Fonte: Imagens geradas pelo Autor

A Tabela 13 apresenta as médias dos tamanhos das partículas obtidas no processamento da vermiculita após cada moagem. Esses resultados foram obtidos por meio da técnica de espalhamento de Luz- LASER mencionada no item 4.2.1.4 . 
Tabela 13 - Médias dos tamanhos, em nanômetros, das partículas de vermiculita obtidas após processamento em moinho

\begin{tabular}{|c|c|c|}
\hline $\begin{array}{c}\text { Tempo de moagem para a } \\
\text { vermiculita piroexpandida }\end{array}$ & Meio de Moagem & $\begin{array}{c}\text { Médias do tamanho das } \\
\text { partículas de vermiculita } \\
\text { após moagem; em } \\
\text { nanômetros }\end{array}$ \\
\hline $2 \mathrm{~h}$ & Água desmineralizada & 626,0 \\
\hline $4 \mathrm{~h}$ & Água desmineralizada & 479,0 \\
\hline $8 \mathrm{~h}$ & Butilglicol & 195,5 \\
\hline $8 \mathrm{~h}$ & Acetato de butilglicol & 195,5 \\
\hline $12 \mathrm{~h}$ & Butilglicol & 170,9 \\
\hline $12 \mathrm{~h}$ & Acetato de butilglicol & 170,9 \\
\hline
\end{tabular}

Fonte: O Autor

Observação: Conforme descrição no item 4.2.2.2, sobre os processos empregados para obtenção das partículas de vermiculita processada, os tamanhos obtidos em cada meio de moagem da vermiculita piroexpandida, Tabela 13, referem-se aos tamanhos médios das partículas obtidas em cada processamento.

\subsubsection{Determinação da massa específica por picnometria de hélio}

Para compor o conjunto de dados de caracterização referentes às partículas de vermiculita, obtidas por processo de moagem, foi realizada a determinação da massa específica por picnometria a hélio de dois pós, obtidos a partir do processamento de moagem por 2 e $4 \mathrm{~h}$ em água da vermiculita piroexpandida original Tabela 14. Foi considerado que a determinação em apenas dois pós seria representativa, uma vez que a moagem destrói a estrutura alveolar da vermiculita piroexpandida, gerando um pó com partículas elementares de morfologia lamelar, que se agregam ao longo do processo de moagem. 
Tabela 14 - Resultado da Picnometria de Hélio - Densidade $\left(\mathrm{g} / \mathrm{cm}^{3}\right)$ dos pós de vermiculita piroexpandida moída por $2 \mathrm{~h}$ e $4 \mathrm{~h}$ em água desmineralizada

\begin{tabular}{|c|c|c|c|}
\hline $\begin{array}{c}\text { Tempo de } \\
\text { processamento }\end{array}$ & Densidade (g/cm $\left.{ }^{3}\right)$, & Desvio Padrão & $\begin{array}{c}\text { Tamanho médio de } \\
\text { partícula (item 5.2.4) }\end{array}$ \\
\hline $2 \mathrm{~h}$ & 2,58 & 0,015 & $626 \mathrm{~nm}$ \\
\hline $4 \mathrm{~h}$ & 2,54 & 0,012 & $479 \mathrm{~nm}$ \\
\hline
\end{tabular}

Fonte: Laboratório de Microestrutura e Eco eficiência do Departamento de Engenharia Civil da Escola Politécnica; determinações feitas para esta Tese (LME - PCC - EPUSP)

Os resultados de densidade obtidos estão coerentes com a densidade da vermiculita, que é apresentada na literatura como variando entre 2,3 e $2,7 \mathrm{~g} / \mathrm{cm}^{3}$, com valor médio de $2,5 \mathrm{~g} / \mathrm{cm}^{3}$ (Webmineral, 2017).

\section{3 - Surgimento de cor em verniz uretânico após adição de partículas de vermiculita processada}

O objetivo desta etapa é o de identificar o aparecimento de cor motivado pela adição de partículas de vermiculita processada ao verniz uretânico incolor.

Para verificação inicial da existência cor gerada pelas partículas de vermiculita processada; as dispersões das partículas de vermiculita em água, sem verniz, foram aplicadas sobre placas de vidro por meio de aplicador tipo quadrangular de barra, cava utilizada; 120 micrômetros (Figura 20).

As imagens das extensões das dispersões de vermiculita sobre placa de vidro transparente e plana são mostradas na Figura 21 para dois tamanhos médios de partícula de vermiculita processada escolhidas para essa avaliação: 195,5 nm e $170,9 \mathrm{~nm}$.

Essas placas de vidro aplicadas com vermiculita processada, sem verniz, foram avaliadas no refletômetro Espectrofotômetro Data Color $600^{\mathrm{TM}}$ (existente na empresa Cromex S.A). 


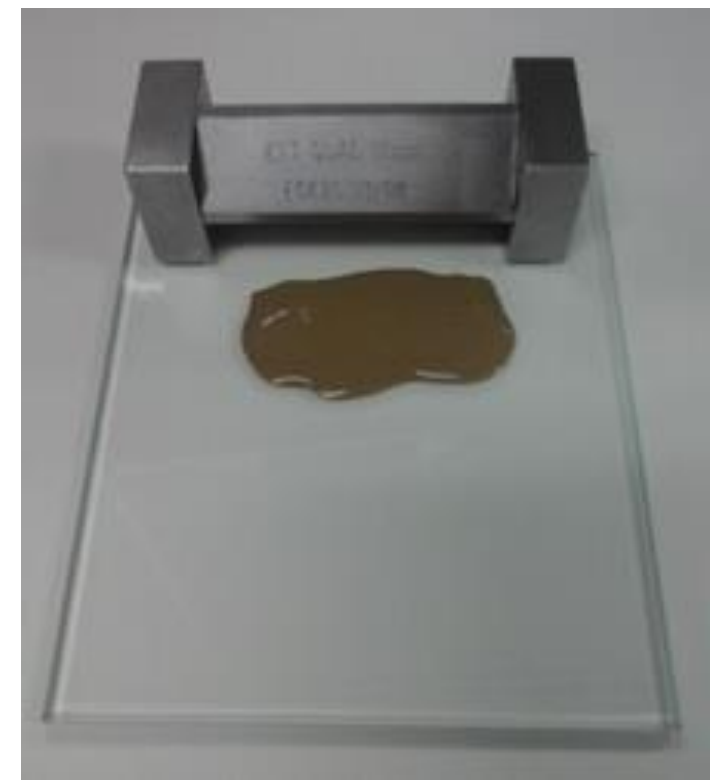

Figura 20 - Aplicador tipo quadrangular, placa de vidro plana e amostra de vermiculita processada em meio aquoso

Fonte: Imagem gerada pelo Autor

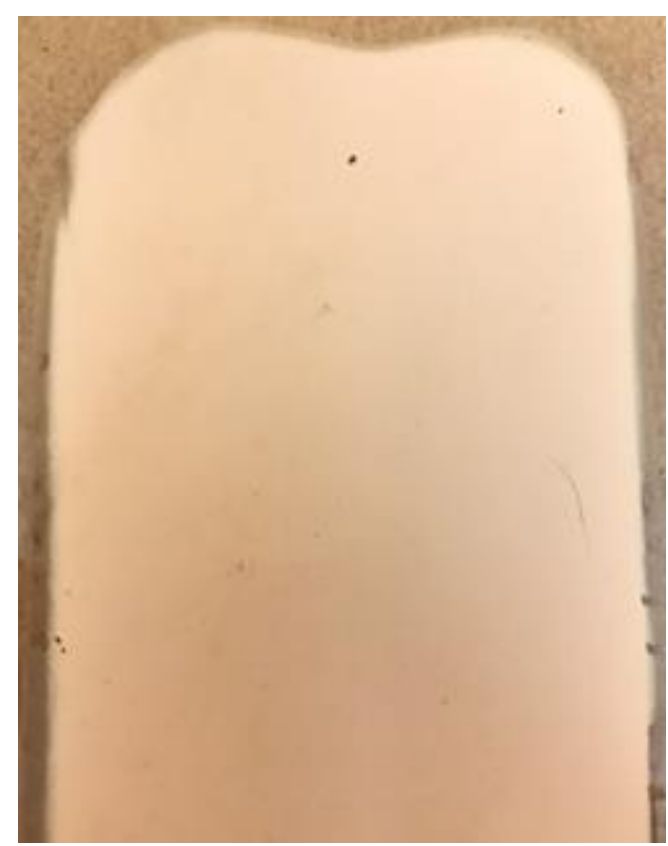

(a)

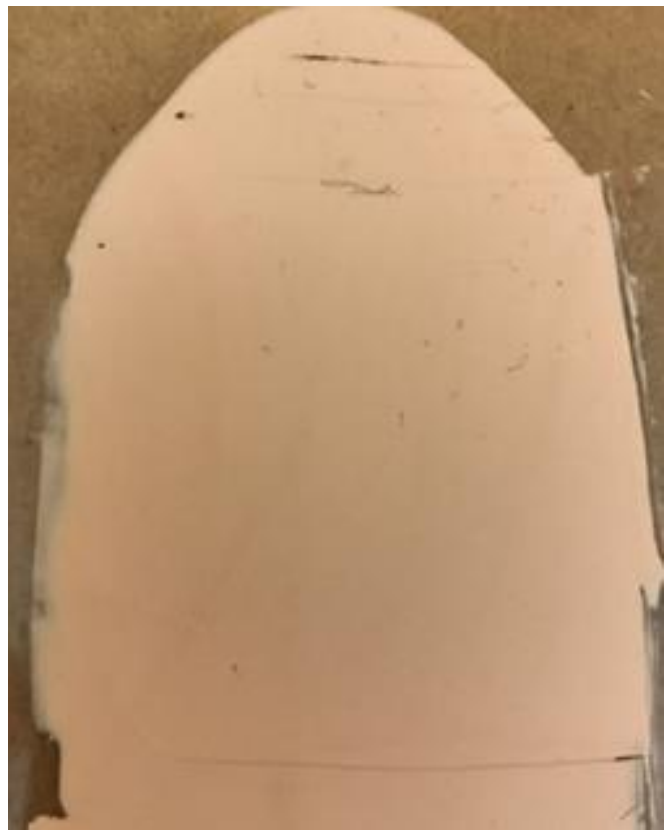

(b)

Figura 21 - Placas de vidro aplicadas com dispersão de vermiculita processada: ( a) vermiculita com $195,5 \mathrm{~nm}$ e ( b ) vermiculita com $170,9 \mathrm{~nm}$

Fonte: Imagens geradas pelo Autor 
Na Figura 22 são mostradas as curvas de refletância para as amostras com tamanhos médios de partícula de 170,9 nm (12 h de processamento) e 195,5 nm (8 h de processamento); ambas processadas com butilglicol.

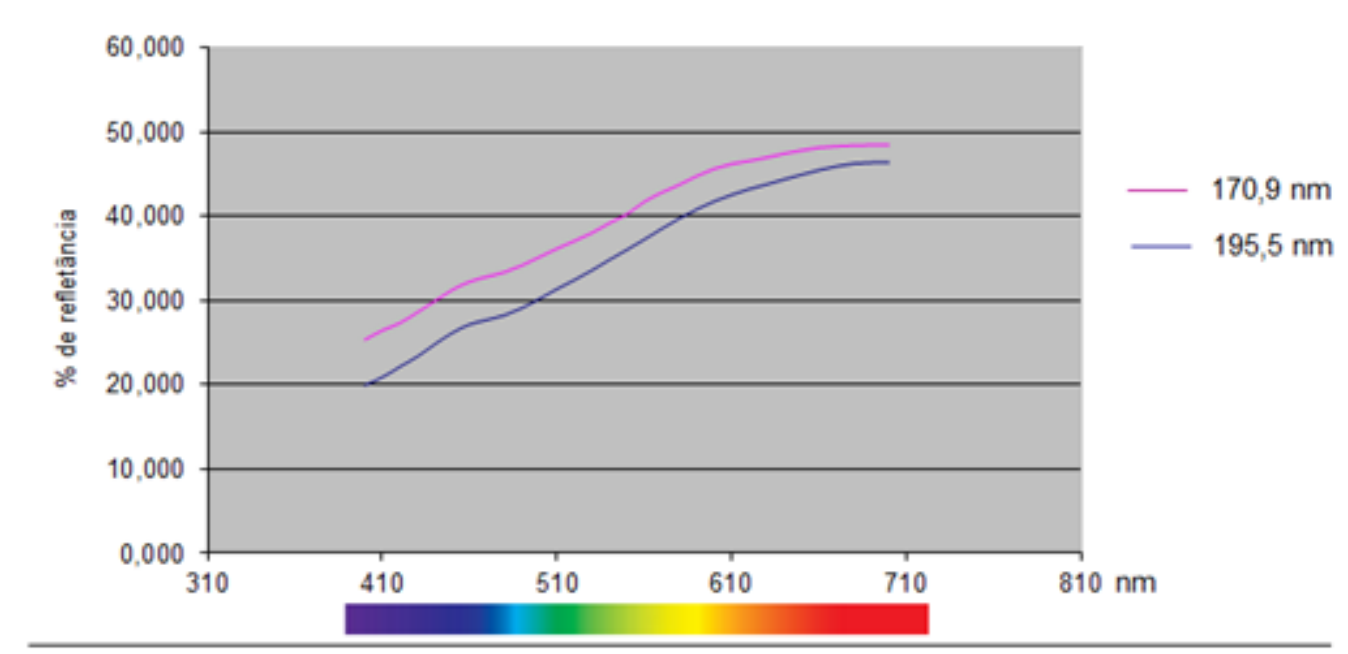

Figura 22 - Curvas da refletância para partículas de vermiculita processada, com tamanhos médios de $170,9 \mathrm{~nm}$ e $195,5 \mathrm{~nm}$

Fontes: O Autor

Na Figura 22, a maior refletância observada para o filme contendo partículas de menor tamanho (170,9 $\mathrm{nm})$, pode estar relacionado com o arranjo destas partículas na superfície do filme. Estas partículas distribuídas, na superfície, propiciam condições para uma maior reflexão do raio luminoso incidente; funcionando como "nano-refletores" inseridos no filme.

A partir da observação visual das placas (Figura 21) e da análise das curvas de refletância (Figura 22), justifica-se a possibilidade de propor o uso das partículas de vermiculita como material promotor de cor, em especial pela elevada reflectância observada na faixa espectral do vermelho, aproximadamente entre $625 \mathrm{~nm}$ e 740 $\mathrm{nm}$.

Para análise de cor das amostras preparadas com vermiculita processada pura e suas combinações com a resina uretânica foi utilizado o espectrofotômetro Datacolor Modelo SF $600^{\mathrm{TM}}$, que emprega o software dedicado Match Pigment Color Tools $2009^{\mathrm{TM}}$. 
As leituras que foram efetuadas na região entre $370 \mathrm{~nm}$ e $700 \mathrm{~nm}$, para todos os sistemas contendo partículas de vermiculita processada, correspondem ao espectro da luz visível. Havendo então, reemissão do raio luminoso incidido na superfície neste intervalo de comprimento de onda; essa reemissão pode ser avaliada por curvas de refletância e; consequentemente interpretadas como fenômeno de cor.

O espectrofotômetro analisou as cores pelo sistema recomendado pela Commission Internationale de L'Eclairage (International Commission on Illumination CIE). O iluminante padrão adotado foi o D65, que corresponde à luz do dia, e foi adotado o ângulo de $10^{\circ}$ como ângulo de observação.

Nas avaliações efetuadas, o eixo $L$ indica o nível de luminosidade, ou seja, o quanto a amostra está clara ou escura. Os valores de $L$ variam no intervalo de zero a cem: $L=0$ para a cor preta e $L=100$ para a cor branca pura. Nesta avaliação, o delta $\mathrm{L},(\Delta \mathrm{L})$, será a diferença do nível de luminosidade entre uma amostra padrão e a amostra em análise.

Os eixos, $a^{*}$ e $b^{*}$, que aparecem nas determinações colorimétricas, indicam cores opostas. Valores positivos no eixo $\mathrm{a}^{*}$ indicam a tonalidade vermelha e, valores negativos no eixo $a^{*}$, indicam a tonalidade verde. No eixo $b^{*}$, valores positivos indicam tonalidade amarela; valores negativos no eixo $b^{*}$; indicam tonalidade azul (FAZENDA et al., 2009).

Na Figura 23 é mostrado, de forma esquemática, o que acaba de ser descrito. 


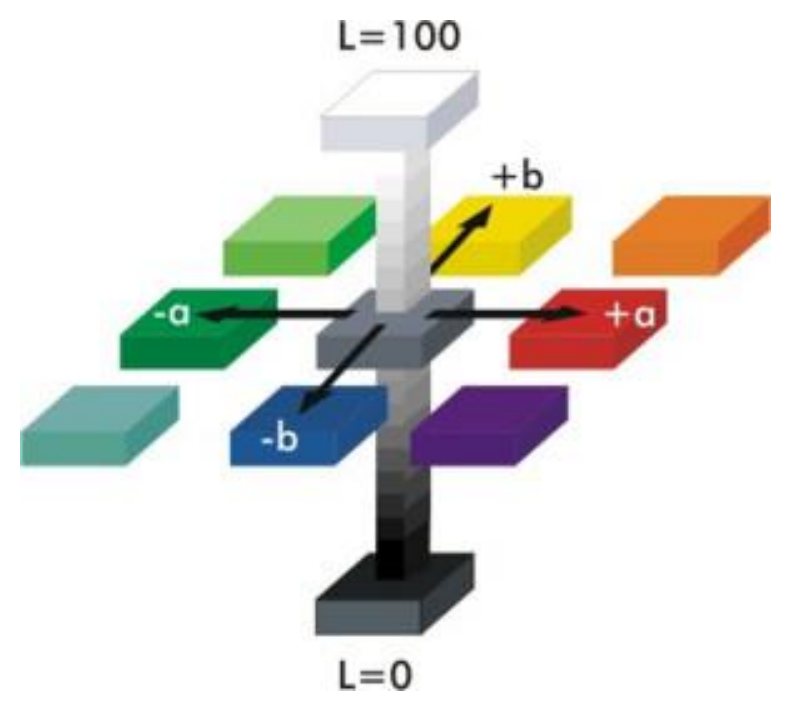

Figura 23 - Representação esquemática do significado das variáveis $a^{*}, b^{*}$ e $L$ de acordo com o sistema recomendado pela "Commission Internationale de L'Eclairage" (International Commission on Illumination - CIE)

Fonte: http://reproducaodacor.blogspot.com.br/2012/09/modelo-cie-lab.html capturada em 10 de julho de 2017

Os respectivos deltas, $\Delta \mathrm{a}^{*}$ e $\Delta \mathrm{b}^{*}$ obtidos nestes eixos, indicam a tendência de cromaticidade ou seja a, existência de dirença de tonalidade na amostra que está sendo avaliada em relação à amostra de referência que no caso deste estudo, foram os dados obtidos na amostra da vermiculita processada em pó sem adição de resina. $E$, o delta $L(\Delta L)$, obtido em leitura comparativa no eixo $L$, indica a diferença na luminosidade da amostra que está sendo analisada em relação à amostra de referência.

Para a análise da cor foi considerada a leitura colorimétrica delta $E(\Delta E)$. Conforme a programação interna do software do fabricante do equipamento; quanto maior o valor apresentado pela leitura do $\Delta \mathrm{E}$, mais distante estará a cor avaliada em relação a cor padrão "inicial” estabelecida na comparação.

\subsubsection{Resultados da avaliação do surgimento de cor e sua interpretação}

Na Figura 24, é mostrada a evolução de cor ocorrida em um dos sistemas estudados nesta Tese.

Nesta Figura 24; a imagem (a) corresponde ao sistema contendo somente resina uretânica, a imagem (b) corresponde ao sistema contendo somente partículas 
de vermiculita processada (626 nm) e a imagem (c) corresponde ao sistema contendo a combinação de vermiculita processada $(626 \mathrm{~nm})$, com a resina uretânica.

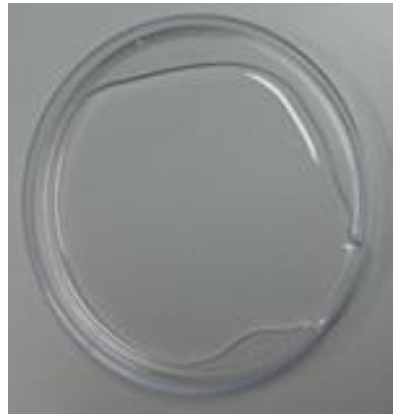

(a)

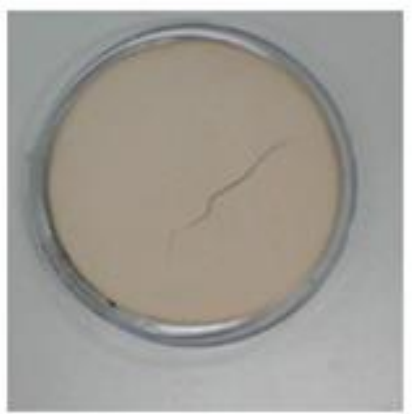

(b)

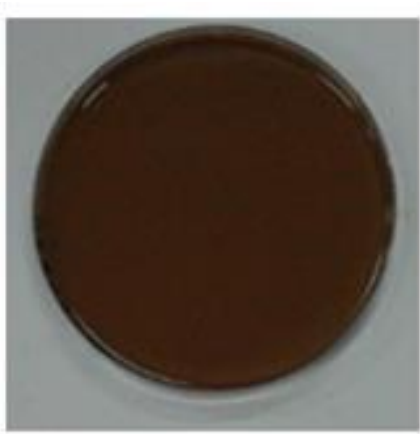

(c)

Figura 24 - Aspecto visual dos sistemas contendo resina e vermiculita em pó: (a) resina uretênica pura; (b) partículas secas de vermiculita processada, $(626 \mathrm{~nm})$; (c) filme obtido a partir da dispersão em resina uretânica com partículas de vermiculita processada, $(626 \mathrm{~nm})$

Fonte: O Autor

A adição do mineral vermiculita à dispersão uretânica gerou um compósito com coloração diferente daquela existente na vermiculita pura, este compósito adquiriu uma coloração de tendência ao vermelho escuro.

Nas Tabelas 15 e 16 são apresentados os resultados de refletância relativos aos corpos de prova VP245-C, VP245-D e VP245-E contendo vermiculita processada em meio aquoso por $2 \mathrm{~h}$, com tamanho de partícula médio $=626 \mathrm{~nm}$ (Tabelas 3 e 13). Nas Tabelas 17 e 18 apresentaram os resultados de refletância relativos aos corpos de prova VP246-C, VP246-D e VP246-E contendo vermiculita processada em meio aquoso por $4 \mathrm{~h}$, com tamanho de partícula médio $=479 \mathrm{~nm}$ (Tabelas 4 e 13).

As variações de refletância observadas na análise dos corpos de prova produzidos a partir de dispersões de resina uretânica contendo vermiculita processada são apresentadas nas Figuras 25 (tamanho médio de partículas da vermiculita processada $=626 \mathrm{~nm}$ ) e Figura 26 (tamanho médio de partículas da vermiculita processada $=479 \mathrm{~nm}$ ). 
Tabela 15 - Dados colorimétricos obtidos nas avaliações dos corpos de prova contendo vermiculita processada $(626 \mathrm{~nm})$ com resina uretânica

\begin{tabular}{|c|c|c|c|c|}
\hline \multicolumn{2}{|c|}{ AMOSTRAS } & $\mathbf{L}^{*}$ & $\mathbf{a}^{*}$ & $\mathbf{b}^{*}$ \\
\hline \multicolumn{2}{|c|}{$\begin{array}{c}\text { Vermiculita processada }(626 \mathrm{~nm}), \\
\text { sem resina }\end{array}$} & 77,24 & 5,71 & 12,24 \\
\hline \multirow{2}{*}{$\begin{array}{c}\text { Sistemas } \\
\text { contendo } \\
\text { resina } \\
\text { uretânica }\end{array}$} & VP245-C & 41,30 & 10,04 & 14,78 \\
\cline { 2 - 5 } & VP245-D & 41,01 & 9,76 & 14,43 \\
\cline { 2 - 5 } & VP245-E & 40,83 & 9,77 & 14,92 \\
\hline
\end{tabular}

Fonte: Resultados de análises realizadas no Refletômetro Espectrofotômetro Data Color $600^{\mathrm{TM}}$ pertencente à Empresa Cromex S.A.

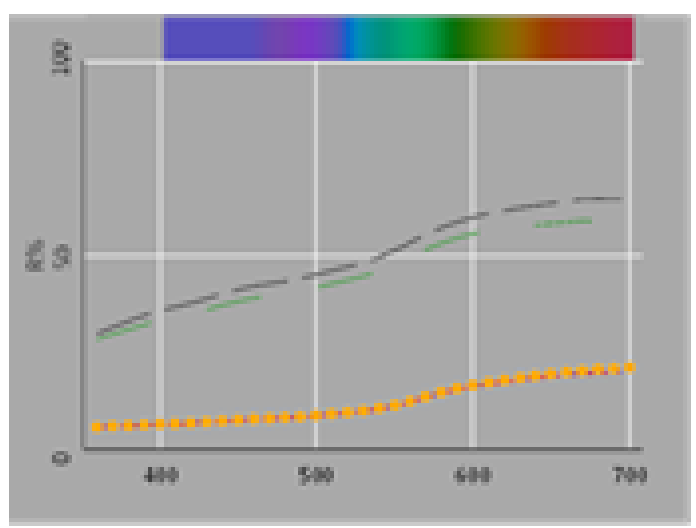

(a)

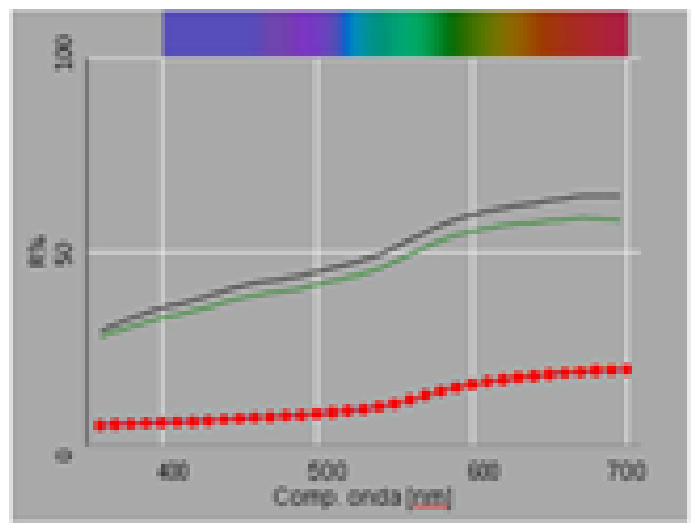

(c)

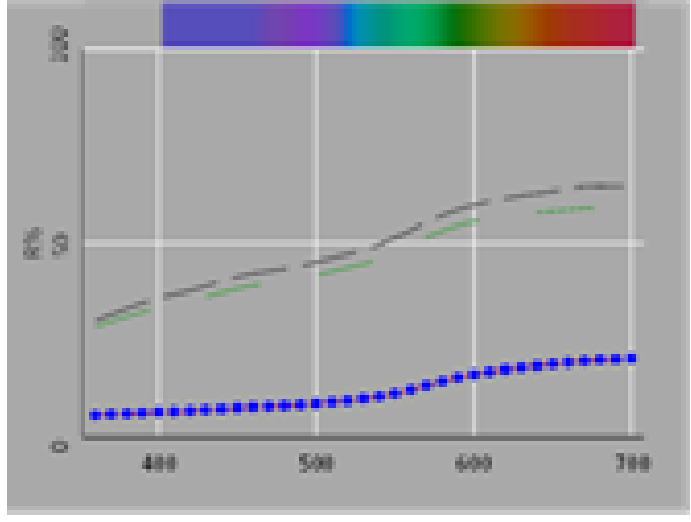

(b)

Figura 25 - Refletância observada nas avaliações dos corpos de prova contendo vermiculita processada (626 nm) com resina uretânica: (a) VP245-C; (b) VP245D; (c) VP245-E

Fonte: Resultados de análises realizadas no Refletômetro Espectrofotômetro Data Color $600^{\mathrm{TM}}$ pertencente à Empresa Cromex S.A 
Tabela 16 - Variações colorimétricas dos corpos de prova contendo vermiculita processada (626 nm) em relação à vermiculita processada sem resina

\begin{tabular}{|c|c|c|c|c|}
\hline AMOSTRAS & $\Delta \mathbf{L}^{*}$ & $\Delta \mathbf{a}^{*}$ & $\Delta \mathbf{b}^{*}$ & $\Delta \mathbf{E}^{*}$ \\
\hline VP245-C & $-35,94$ & 4,33 & 2,54 & 36,29 \\
\hline VP245-D & $-36,23$ & 4,05 & 2,19 & 36,52 \\
\hline VP245-E & $-36,41$ & 4,05 & 2,67 & 36,73 \\
\hline
\end{tabular}

Fonte: Resultados de análises realizadas no Refletômetro Espectrofotômetro Data Color $600^{\mathrm{TM}}$ pertencente à Empresa Cromex S.A

Tabela 17 - Dados colorimétricos obtidos nas avaliações dos corpos de prova contendo vermiculita processada $(479 \mathrm{~nm})$ com resina uretânica

\begin{tabular}{|c|c|c|c|c|}
\hline \multicolumn{2}{|c|}{ AMOSTRAS } & $\mathbf{L}^{*}$ & $\mathbf{a}^{*}$ & $\mathbf{b}^{*}$ \\
\hline \multicolumn{2}{|c|}{$\begin{array}{c}\text { Vermiculita processada }(479 \mathrm{~nm}), \\
\text { sem resina }\end{array}$} & 74,97 & 5,53 & 11,95 \\
\hline \multirow{2}{*}{$\begin{array}{c}\text { Sistemas } \\
\text { contendo } \\
\text { resina } \\
\text { uretânica }\end{array}$} & VP246-C & 40,39 & 9,53 & 14,20 \\
\cline { 2 - 5 } & VP246-D & 39,96 & 9,10 & 13,68 \\
\cline { 2 - 5 } & VP246-E & 40,08 & 8,14 & 12,47 \\
\hline
\end{tabular}

Fonte: Resultados de análises realizadas no Refletômetro Espectrofotômetro Data Color $600^{\mathrm{TM}}$ pertencente à Empresa Cromex S.A 


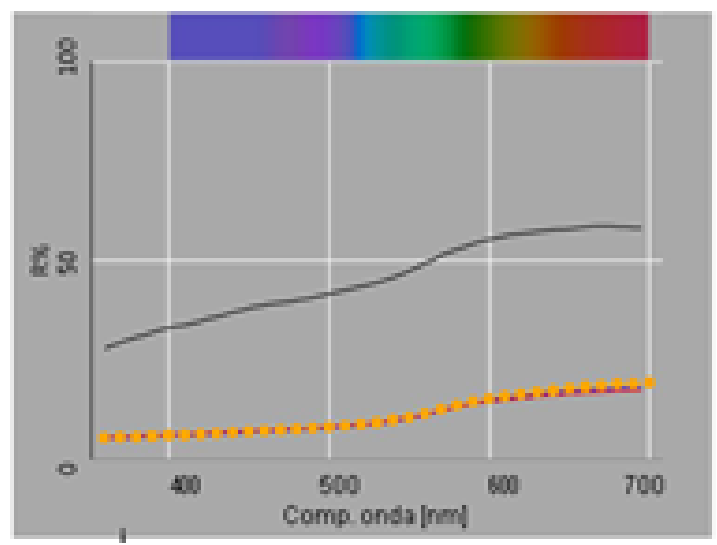

(a)

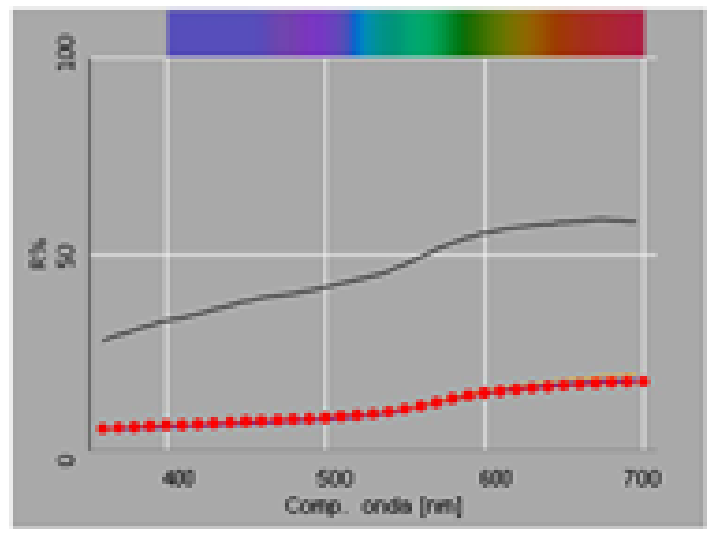

(c)

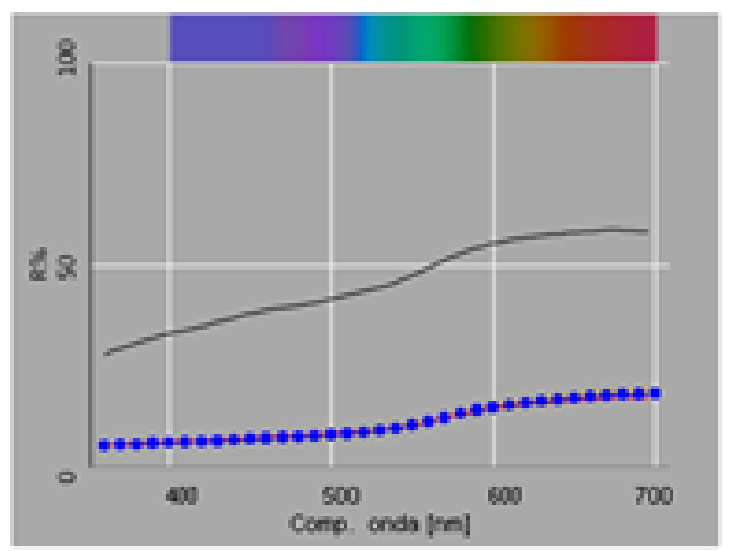

(b)

Figura 26 - Refletância observada nas avaliações dos corpos de prova contendo vermiculita processada $(479 \mathrm{~nm})$ com resina uretânica: (a) VP246-C; (b) VP246D; (c) VP246-E

Fonte: Resultados de análises realizadas no Refletômetro Espectrofotômetro Data Color $600^{\mathrm{TM}}$ pertencente à Empresa Cromex S.A

Tabela 18 - Variações colorimétricas dos corpos de prova contendo vermiculita processada $479 \mathrm{~nm}$ em relação à vermiculita processada sem resina

\begin{tabular}{|c|c|c|c|c|}
\hline AMOSTRAS & $\Delta \mathbf{L}^{*}$ & $\Delta \mathbf{a}^{*}$ & $\Delta \mathbf{b}^{*}$ & $\Delta \mathbf{E}^{*}$ \\
\hline VP246-C & $-34,60$ & 3,99 & 2,21 & 34,90 \\
\hline VP246-D & $-35,01$ & 3,57 & 1,73 & 35,23 \\
\hline VP246-E & $-34,89$ & 2,61 & 0,53 & 34,99 \\
\hline
\end{tabular}

Fonte: Resultados de análises realizadas no Refletômetro Espectrofotômetro Data Color $600^{\text {TM }}$ pertencente à Empresa Cromex S.A 
Discussão: Avaliação do desenvolvimento de cor na resina uretânica com adição de vermiculita processada

Nas Figuras 25 e 26 observou-se que todas as amostras contendo vermiculita combinada com resina uretânica apresentaram refletância acentuada na região compreendida entre $600 \mathrm{~nm}$ e $700 \mathrm{~nm}$. A cor correspondente a essa região do espectro visível é o vermelho (como pode ser visto na parte superior dessas figuras, geradas pelo software do equipamento, onde é apresentado o espectro da luz visível).

Na Figura 27 é apresentada a variação dos valores de $\Delta a^{*}$ e $\Delta b^{*}$ com as relações [massa de vermiculita] / [massa de resina]. Nessa figura observou-se que em todas as amostras de resina com adições de vermiculita processada houve um aumento na tonalidade vermelha em relação às amostras de vermiculita processada, uma vez que os valores de $\Delta \mathrm{a}^{*}$ foram sempre positivos. Também nessa figura, observou-se um aumento na tonalidade amarela em relação às amostras de vermiculita processada, uma vez que os valores de $\Delta b^{*}$ foram sempre positivos. Ou seja, com a adição da resina uretânica, a cor do sistema [vermiculita processada + resina] variou em relação à cor da vermiculita processada pura, não importando o tamanho médio das partículas da vermiculita processada adicionada.

Esse efeito de intensificação de cor foi tão mais intenso quanto maior o tamanho médio de partícula.

A evolução das tonalidades de cor com a concentração de vermiculita adicionada, no entanto, depende do tamanho médio de partícula da vermiculita processada adicionada. A cor desenvolvida em vernizes com adição de vermiculita processada com partículas maiores (amostras da série VP245, com tamanho médio de partícula $=626 \mathrm{~nm}$ ) aparentemente foi pouco dependente da quantidade de vermiculita adicionada, conforme mostraram os valores tanto de $\Delta a^{*}$ quanto de $\Delta b^{*}$. Já a cor desenvolvida em vernizes com adição de vermiculita processada com partículas menores (amostras da série VP246, com tamanho médio de partícula = $479 \mathrm{~nm}$ ) depende da quantidade de vermiculita adicionada, conforme mostraram os valores tanto de $\Delta \mathrm{a}^{*}$ quanto de $\Delta \mathrm{b}^{*}$, que são decrescentes com o aumento do teor de adição de vermiculita, ou seja, com a adição de quantidades crescentes de 
vermiculita, a cor do sistema [verniz uretânico + vermiculita] foi se tornando cada vez mais próxima da cor da vermiculita processada.

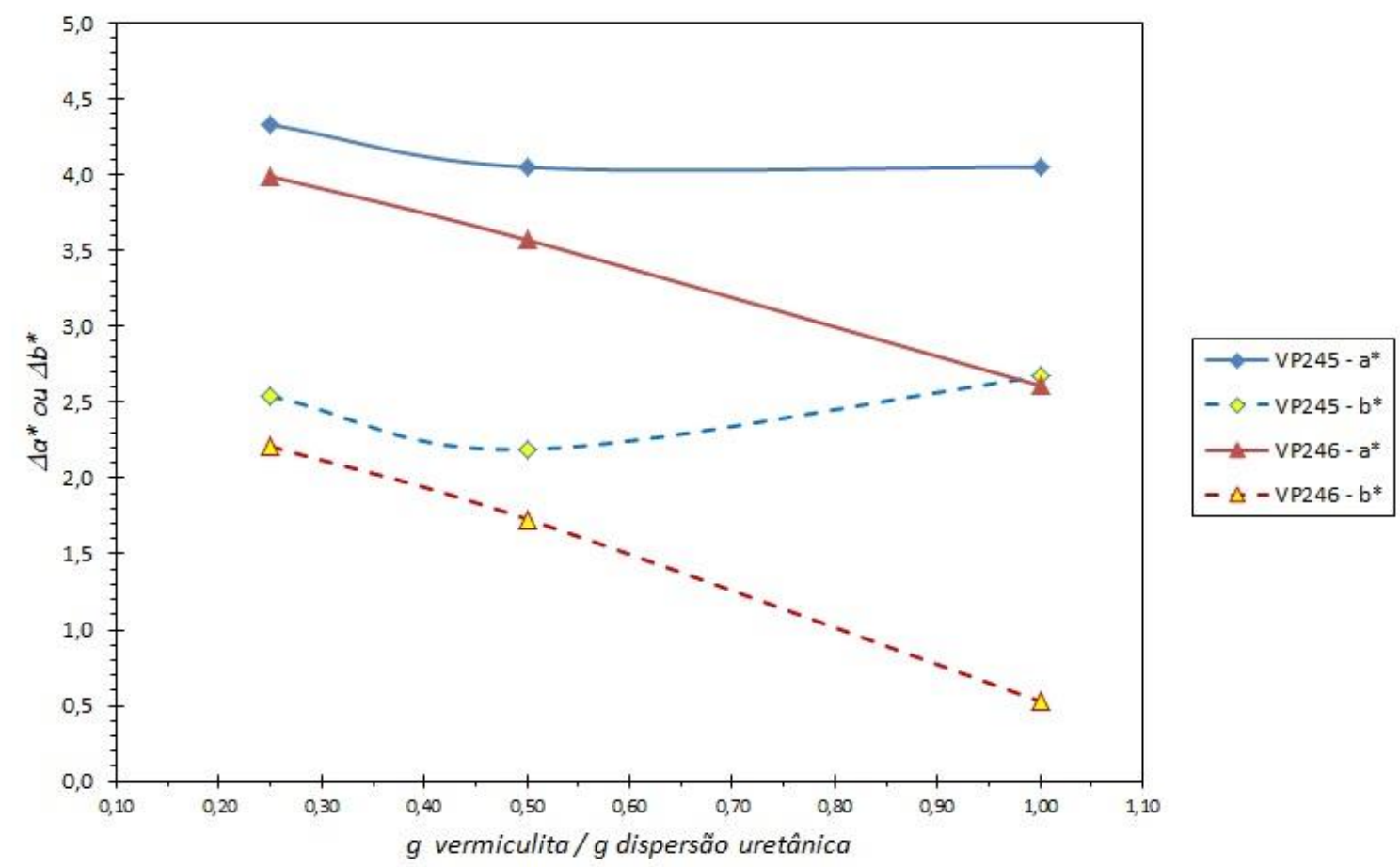

Figura 27 - Variação de $\Delta a^{*}$ e $\Delta b^{*}$ com as relações [massa de vermiculita] / [massa de resina] (em $\mathrm{g} / \mathrm{g}$ ) para as duas séries de amostras estudadas nesta Tese: VP245 (tamanho médio de partículas = $626 \mathrm{~nm}$ ) e VP246 (tamanho médio de partículas = $479 \mathrm{~nm}$ )

Fonte : Figura do Autor

A variação de cor percebida entre a vermiculita seca e os compósitos de vermiculita (vermiculita e resina uretânica), poderia ser justificada considerando fenômenos de espalhamento e reemissão do raio luminoso incidido nos sistemas avaliados.

A incidência de luz visível sobre os pós de vermiculita processada originou interações com estes pós criando espalhamento e reemissão de parte da luz visível exibindo dessa forma uma coloração característica para as partículas de vermiculita pura.

Quando estas partículas de vermiculita foram imersas na resina uretânica, formaram compósitos com coloração diferente da coloração da vermiculita pura sem 
resina. A luz visível, incidindo sobre esse compósito, criou outro padrão de espalhamento e reflexão. O compósito passou então a se comportar distintamente.

A onda de luz visível que incidiu sobre o compósito, vermiculita-resina uretânica, sofreu dispersão, absorção e reemissão de parte da onda incidente (Rocha, et al, 2010), deixando o sistema visualmente mais escuro em relação à cor observada na vermiculita processada pura.

$\mathrm{Na}$ Figura 28 é mostrada a variação dos valores de $\Delta \mathrm{L}^{*}$ e $\Delta \mathrm{E}^{*}$ com as relações [massa de vermiculita] / [massa de resina]. Nessa figura observou-se que em todas as amostras de verniz, com adições de vermiculita processada, ocorreu redução de luminosidade em relação à vermiculita em pó (valores de $\Delta L^{*}$ negativos, eixo vertical à direita). Por analise visual, sabe-se que as partículas de vermiculita processada em pó são partículas lamelares e, é importante não esquecer desse fato; estas são bastante brilhantes. Essa diminuição da luminosidade talvez possa ser explicada por uma perda da orientação preferencial das partículas de vermiculita quando imersas no verniz. É possível que as partículas lamelares de vermiculita, que se orientaram expondo suas faces "mais refletivas", seus planos (001), quando analisadas na forma de pó, possam ter ficado "desorientadas" no seio da matriz uretânica e, os resultados para os sistemas [vermiculita + resina uretânica] teriam um aspecto menos refletivo (mais "mate"), apresentando resultados de $\Delta L^{*}$ negativos. Essa, no entanto, é uma interpretação fenomenológica; uma vez que essas amostras não foram analisadas por técnicas que eventualmente poderiam colocar em evidência essa explicação ( como, por exemplo, micrografias do filme [vermiculita + resina uretânica crio-fraturado] ).

Esse efeito de redução de luminosidade foi tão mais intenso quanto maior o tamanho médio de partícula.

Os valores de $\Delta \mathrm{E}^{*}$ mostraram que a adição de partículas de vermiculita processada com maior tamanho médio, (no verniz), implicou em maior diferença de cor em relação à cor da vermiculita em pó. Com relação ao efeito do aumento da concentração de partículas, aparentemente a adição de partículas maiores levaram a um aumento monotônico do valor de $\Delta \mathrm{E}^{\star}$; fato que não foi observado quando se adicionaram partículas menores, mas como as diferenças observadas nos valores 
de $\Delta \mathrm{E}^{*}$, em relação ao aumento das concentrações, foi muito pequeno e, como não foram efetuadas repetições para uma análise estatística adequada, essa observação deve ser tomada sob reserva.

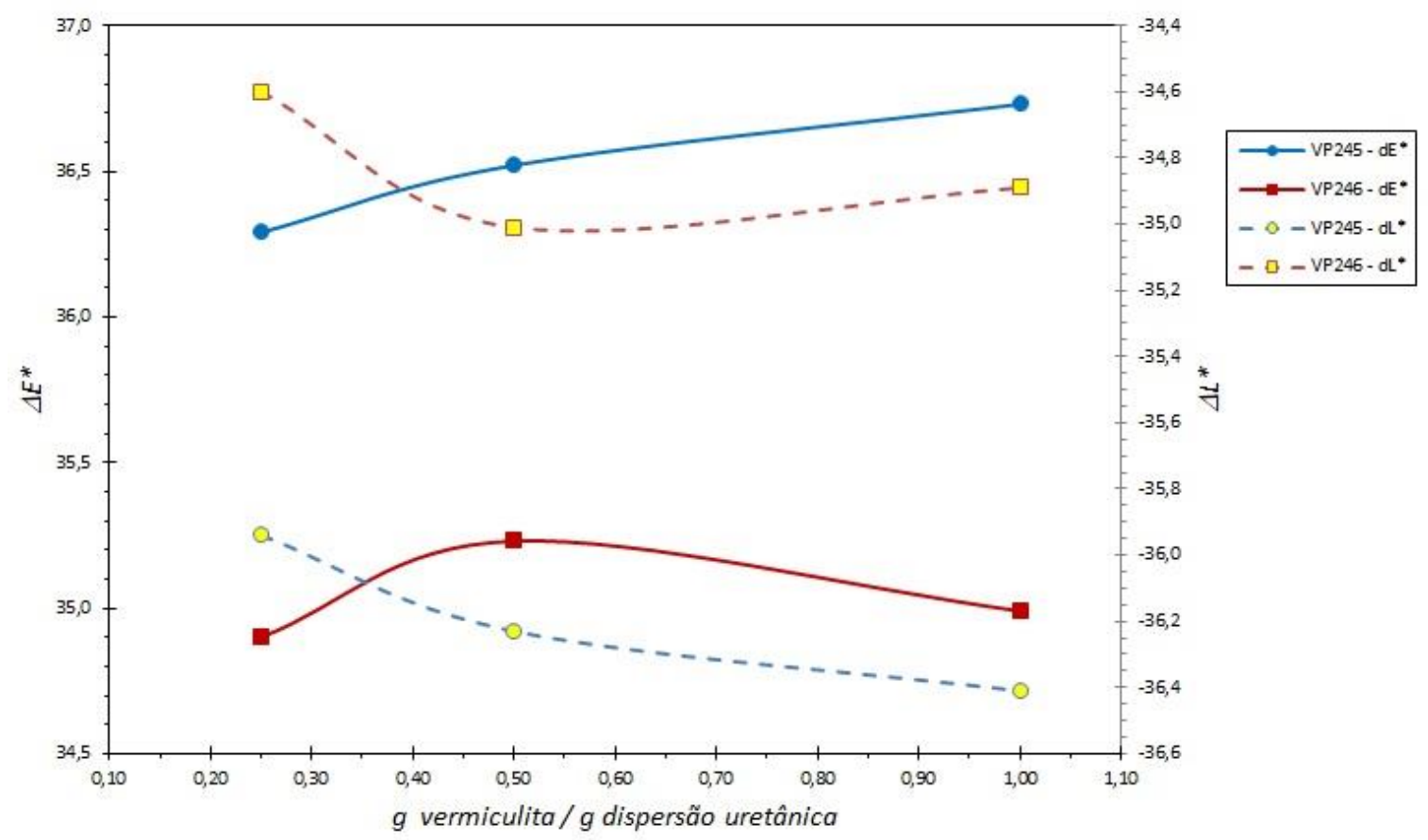

Figura 28 - Variação de $\Delta \mathrm{E}^{*}$ (eixo vertical à esquerda) e $\Delta \mathrm{L}^{*}$ (eixo vertical à direita) com as relações [massa de vermiculita] / [massa de resina] (em $\mathrm{g} / \mathrm{g}$ ) para as duas séries de amostras estudadas nesta Tese: VP245 (tamanho médio de partículas $=626 \mathrm{~nm}$ ) e VP246 (tamanho médio de partícula $=479$ $\mathrm{nm})$

Fonte : Figura do Autor

5.3.2 Estudo da cor em vernizes automotivos aplicados sobre tintas de cores preta e prata

Como consequência da análise de refletância apresentada pelas partículas da vermiculita processada e o estudo do surgimento de cor na resina uretânica, o trabalho prosseguiu avaliando o efeito da presença de vermiculita processada em verniz uretânico de dois componentes utilizado em pinturas automotivas.

Na Figura 29 é mostrado o esquema utilizado para análise do surgimento de cor nos sistemas de verniz uretânico automotivo contendo partículas de vermiculita processada. 


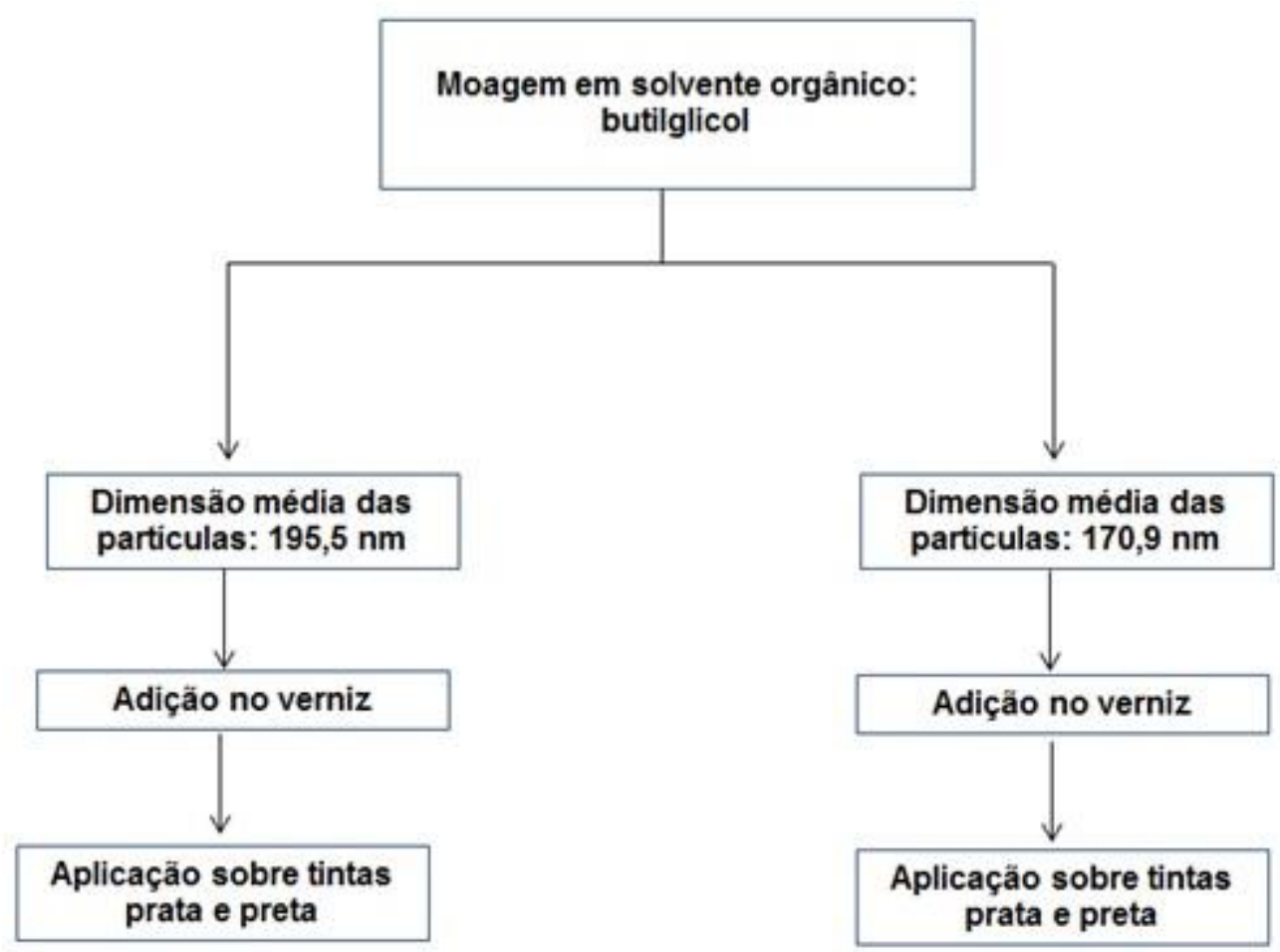

Figura 29 - Representação esquemática do processo de preparação das aplicações sobre tintas preta e prata

Fonte: Esquema produzido pelo Autor.

Ao verniz automotivo foram adicionadas partículas de vermiculita processada em quantidades apresentadas nas Tabelas 5 e 6 .

Os aspectos visuais das chapas aplicadas com verniz aditivado com partículas de vermiculita processada podem ser observados na Figura 30. 


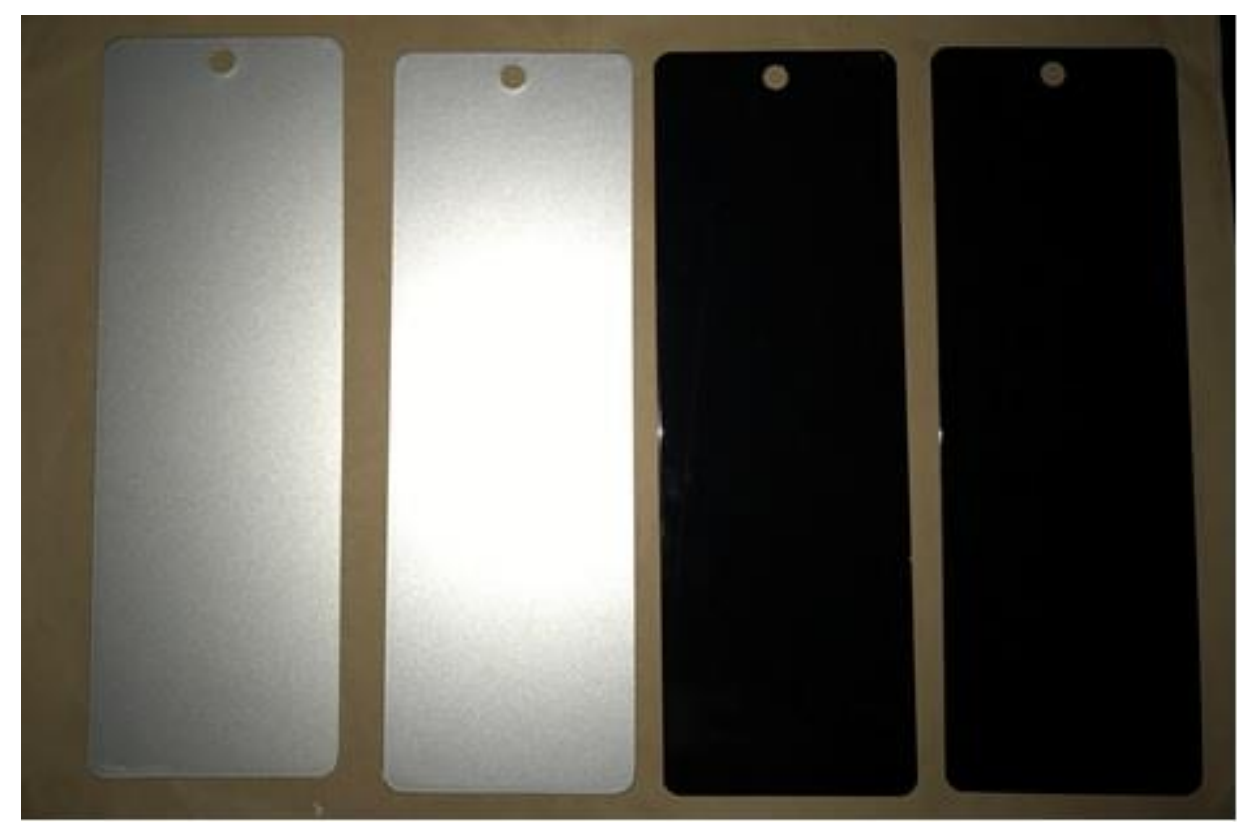

Figura 30 - Chapas pintadas com verniz contendo partículas de vermiculita processada sobre as cores prata e preto

Fonte: Imagem gerada pelo Autor

Sob as tintas aplicadas (cujo aspecto é mostrado na Figura 30) existem camadas de revestimentos conforme esquema mostrado na Figura 31.

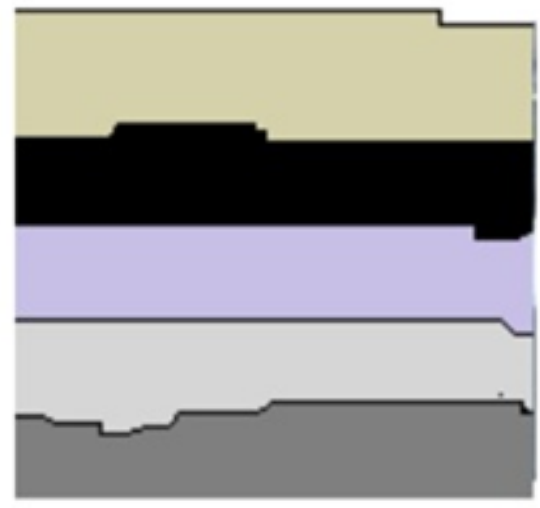

\section{Verniz}

Base Coat

Primer

\section{E-Coat}

\section{Substrato}

Figura 31 - Esquema representativo das camadas de tinta e verniz aplicados em cada chapa avaliada neste estudo

Fonte: O Autor

Deste esquema de aplicação automotivo apresentado na Figura 31, torna-se necessário considerar a cor dos "base coats" (cores preta e prata) sob verniz sem adição de partículas de vermiculita para avaliar como o verniz ao qual foi adicionada a vermiculita processada interfere sobre estas cores. 
Vale considerar que os demais itens aplicados sob os "bases coats", o "primer" que é uma tinta de fundo, e o "e-coat" que também uma tinta de fundo, não interferiram na avaliação de cor pois a camada do "base coat" os recobriu e foi opaca para estas tintas

A avaliação de cor nas chapas aplicadas conforme esquema mostrado na Figura 31, foi efetuada a partir de dados obtidos no espectrofotômetro multiangular MA68II ${ }^{\mathrm{TM}}$ (X-Rite Inc.) pertencente à empresa "Axalta Coating". As leituras foram efetuadas nos ângulos de $45^{\circ}$ e $75^{\circ}$ de reflexão da luz, ângulos esses típicos de análises de cor no setor automotivo. Os dados foram tratados pelo software do equipamento (software X-Rite Color Master - Metallix ${ }^{\mathrm{TM}}$ ).

Nas Tabelas 19 e 20 são mostrados os resultados experimentais obtidos nessa avaliação de cor, respectivamente para as placas pintadas com tinta prata e preta.

Nas Figuras 32-35 são mostradas as variações dos valores de $\Delta \mathrm{L}^{*}, \Delta \mathrm{a}^{*}$ e $\Delta \mathrm{b}^{*}$ em relação à quantidade de vermiculita processada para o caso das placas pintadas com tinta prata, enquanto nas Figuras 36-39 são mostradas a variações dos valores de $\Delta \mathrm{L}^{*}, \Delta \mathrm{a}^{*} \mathrm{e} \Delta \mathrm{b}^{*}$ em relação à quantidade de vermiculita processada para o caso das placas pintadas com tinta preta.

Tabela 19 - Resultados das leituras de cor dos painéis pintados com tinta prata nos ângulos de leitura de $45^{\circ}$ e $75^{\circ}$

\begin{tabular}{|c|c|c|c|c|c|c|c|c|c|c|c|c|}
\hline \multirow{2}{*}{$\begin{array}{c}\text { Codificação } \\
\text { das amostras }\end{array}$} & \multicolumn{9}{|c|}{$45^{\circ}$} & \multicolumn{6}{|c|}{$75^{\circ}$} \\
\cline { 2 - 13 } & $\mathrm{L}^{*}$ & $\Delta \mathrm{L}^{*}$ & $\mathrm{a}^{*}$ & $\Delta \mathrm{a}^{*}$ & $\mathrm{~b}^{*}$ & $\Delta \mathrm{b}^{*}$ & $\mathrm{~L}^{*}$ & $\Delta \mathrm{L}^{*}$ & $\mathrm{a}^{*}$ & $\Delta \mathrm{a}^{*}$ & $\mathrm{~b}^{*}$ & $\Delta \mathrm{b}^{*}$ \\
\hline PA_B_0 & 64,60 & - & $-1,23$ & - & $-2,23$ & - & 40,22 & - & $-1,47$ & - & $-3,65$ & - \\
\hline PA_2h_0,5 & 64,90 & 0,30 & $-1,25$ & $-0,02$ & $-1,81$ & 0,41 & 40,28 & 0,06 & $-1,48$ & $-0,01$ & $-3,20$ & 0,45 \\
\hline PA_2h_1,0 & 64,96 & 0,36 & $-1,23$ & 0,00 & $-1,10$ & 1,13 & 40,70 & 0,48 & $-1,51$ & $-0,04$ & $-2,57$ & 1,09 \\
\hline PA_2h_2,0 & 64,62 & 0,02 & $-1,19$ & 0,04 & $-0,02$ & 2,21 & 40,58 & 0,36 & $-1,48$ & $-0,02$ & $-1,56$ & 2,10 \\
\hline PA_12h_0,5 & 65,20 & 0,60 & $-1,29$ & $-0,07$ & $-1,86$ & 0,37 & 41,25 & 1,03 & $-1,52$ & $-0,06$ & $-3,31$ & 0,35 \\
\hline PA_12h_1,0 & 66,10 & 1,50 & $-1,28$ & $-0,05$ & $-1,18$ & 1,04 & 42,48 & 2,26 & $-1,61$ & $-0,14$ & $-2,67$ & 0,98 \\
\hline PA_12h_2,0 & 66,47 & 1,87 & $-1,30$ & $-0,07$ & $-0,21$ & 2,01 & 43,67 & 3,45 & $-1,64$ & $-0,18$ & $-1,61$ & 2,05 \\
\hline
\end{tabular}

Fonte: Tabela gerada pelo Autor a partir de dados obtidos nos laboratórios da Axalta Coating Corporate 
Tabela 20 - Resultados das leituras de cor dos painéis pintados com tinta preta nos ângulos de leitura de $45^{\circ}$ e $75^{\circ}$

\begin{tabular}{|l|c|c|c|c|c|c|c|c|c|c|c|c|}
\hline \multirow{2}{*}{$\begin{array}{c}\text { Codificação } \\
\text { das amostras }\end{array}$} & \multicolumn{5}{|c|}{$45^{\circ}$} & \multicolumn{6}{|c|}{$75^{\circ}$} \\
\cline { 2 - 12 } & $\mathrm{L}^{*}$ & $\Delta \mathrm{L}^{*}$ & $\mathrm{a}^{*}$ & $\Delta \mathrm{a}^{*}$ & $\mathrm{~b}^{*}$ & $\Delta \mathrm{b}^{*}$ & $\mathrm{~L}^{*}$ & $\Delta \mathrm{L}^{*}$ & $\mathrm{a}^{*}$ & $\Delta \mathrm{a}^{*}$ & $\mathrm{~b}^{*}$ & $\Delta \mathrm{b}^{*}$ \\
\hline PO_B_0 & 1,13 & - & 0,00 & - & $-0,32$ & - & 0,99 & - & $-0,03$ & - & $-0,12$ & - \\
\hline PO_2h_0,5 & 1,23 & 0,10 & 0,04 & 0,04 & $-0,28$ & 0,04 & 1,07 & 0,08 & 0,00 & 0,03 & $-0,19$ & $-0,07$ \\
\hline PO_2h_1,0 & 1,66 & 0,52 & 0,00 & 0,00 & $-0,27$ & 0,04 & 1,37 & 0,38 & $-0,03$ & 0,00 & $-0,12$ & 0,00 \\
\hline PO_2h_2,0 & 1,57 & 0,43 & $-0,03$ & $-0,02$ & $-0,24$ & 0,08 & 1,33 & 0,34 & 0,00 & 0,03 & $-0,14$ & $-0,02$ \\
\hline PO_12h_0,5 & 1,20 & 0,06 & 0,04 & 0,04 & $-0,28$ & 0,04 & 1,12 & 0,13 & 0,01 & 0,04 & $-0,12$ & 0,00 \\
\hline PO_12h_1,0 & 1,61 & 0,48 & $-0,03$ & $-0,03$ & $-0,22$ & 0,10 & 1,46 & 0,47 & 0,00 & 0,04 & $-0,23$ & $-0,11$ \\
\hline PO_12h_2,0 & 1,97 & 0,83 & $-0,02$ & $-0,01$ & $-0,41$ & $-0,09$ & 1,81 & 0,82 & $-0,02$ & 0,01 & $-0,25$ & $-0,13$ \\
\hline
\end{tabular}

Fonte: Tabela gerada pelo Autor a partir de dados obtidos nos laboratórios da Axalta Coating Corporate

\section{Legenda para as Tabelas 19 e 20}

PA : série de ensaios da tinta prata ; PO : série de ensaios da tinta preta.

B_0 : Prova em branco.

8h e 12h: tempos de moagem da vermiculita processada, correspondendo respectivamente a tamanhos médios de partícula de 195,5 $\mathrm{nm}$ e 170,9 $\mathrm{nm}$ ref. (Tabelas 5 e 6).

0,$5 ; 1,0 ; 2,0$ : massa de partículas de vermiculita adicionada em um total de $120 \mathrm{~g}$ de verniz (100g de verniz + $20 \mathrm{~g}$ de agente de cura) ref. (Tabelas 5 e 6 )

$L^{*}$ : Faixa de luminosidade, valor $L=0$ para a luminosidade do preto absoluto e $L=100$ para a luminosidade do branco absoluto.

$\mathbf{a}^{*}: a^{*}$ negativo, tendência ao verde; $a^{*}$ positivo, tendência ao vermelho.

$\mathbf{b}^{*}: b^{*}$ negativo, tendência ao azul e $b^{*}$ positivo, tendência ao amarelo.

$\Delta \mathbf{L}^{*}, \Delta \mathbf{a}^{*} \mathrm{e} \boldsymbol{\Delta \mathbf { b } ^ { * }}$; correspondem às diferenças entre os valores das amostras avaliadas e o valor do ensaio em branco para as coordenadas $L^{*} ; a^{*} e b^{*}$ respectivamente. 


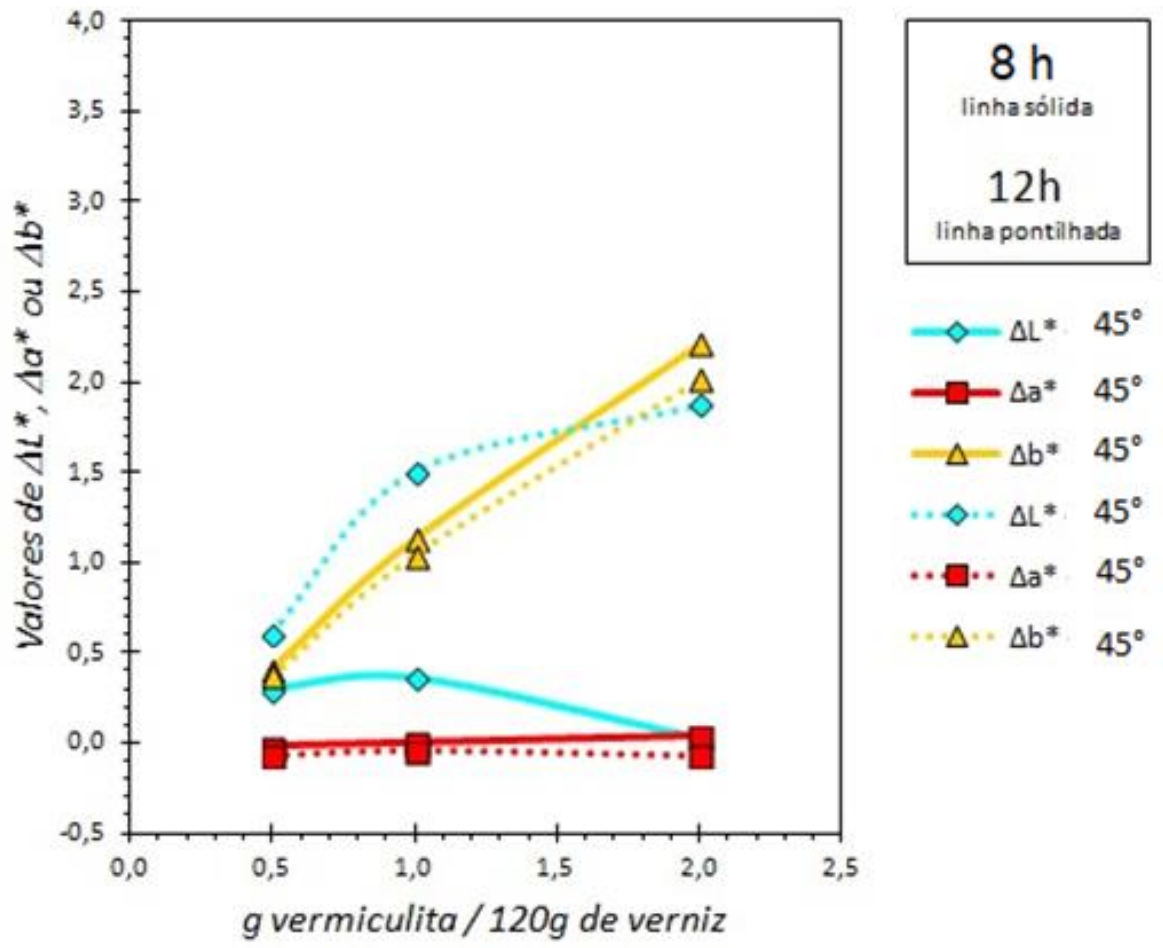

Figura 32 - Variação dos valores de $\Delta \mathrm{L}^{*}, \Delta \mathrm{a}^{*}$ e $\Delta \mathrm{b}^{*}$ em relação à quantidade de vermiculita processada para placas pintadas com tinta prata - leituras efetuadas no ângulo de $45^{\circ}$ de reflexão da luz. 8 h e 12 h: tempos de moagem da vermiculita processada, correspondendo respectivamente a tamanhos médios de partícula de 195,5 nm e 170,9 nm Fonte : o Autor
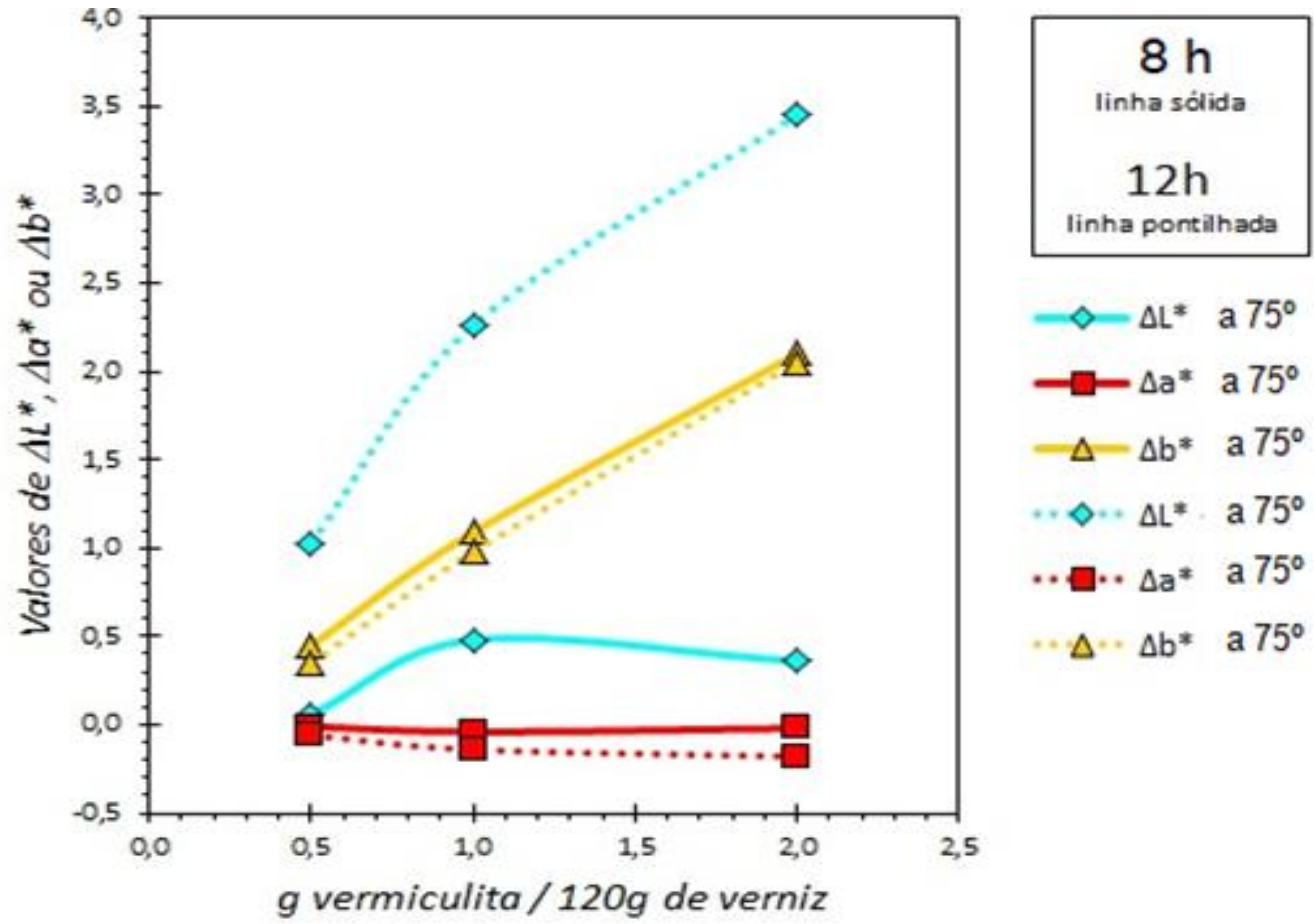

Figura 33 - Variação dos valores de $\Delta \mathrm{L}^{*}, \Delta \mathrm{a}^{*}$ e $\Delta \mathrm{b}^{*}$ em relação à quantidade de vermiculita processada para placas pintadas com tinta prata - leituras efetuadas no ângulo de $75^{\circ}$ de reflexão da luz $8 \mathrm{~h}$ e $12 \mathrm{~h}$ : tempos de moagem da vermiculita processada, correspondendo respectivamente a tamanhos médios de partícula de $195,5 \mathrm{~nm}$ e $170,9 \mathrm{~nm}$ Fonte: o Autor 


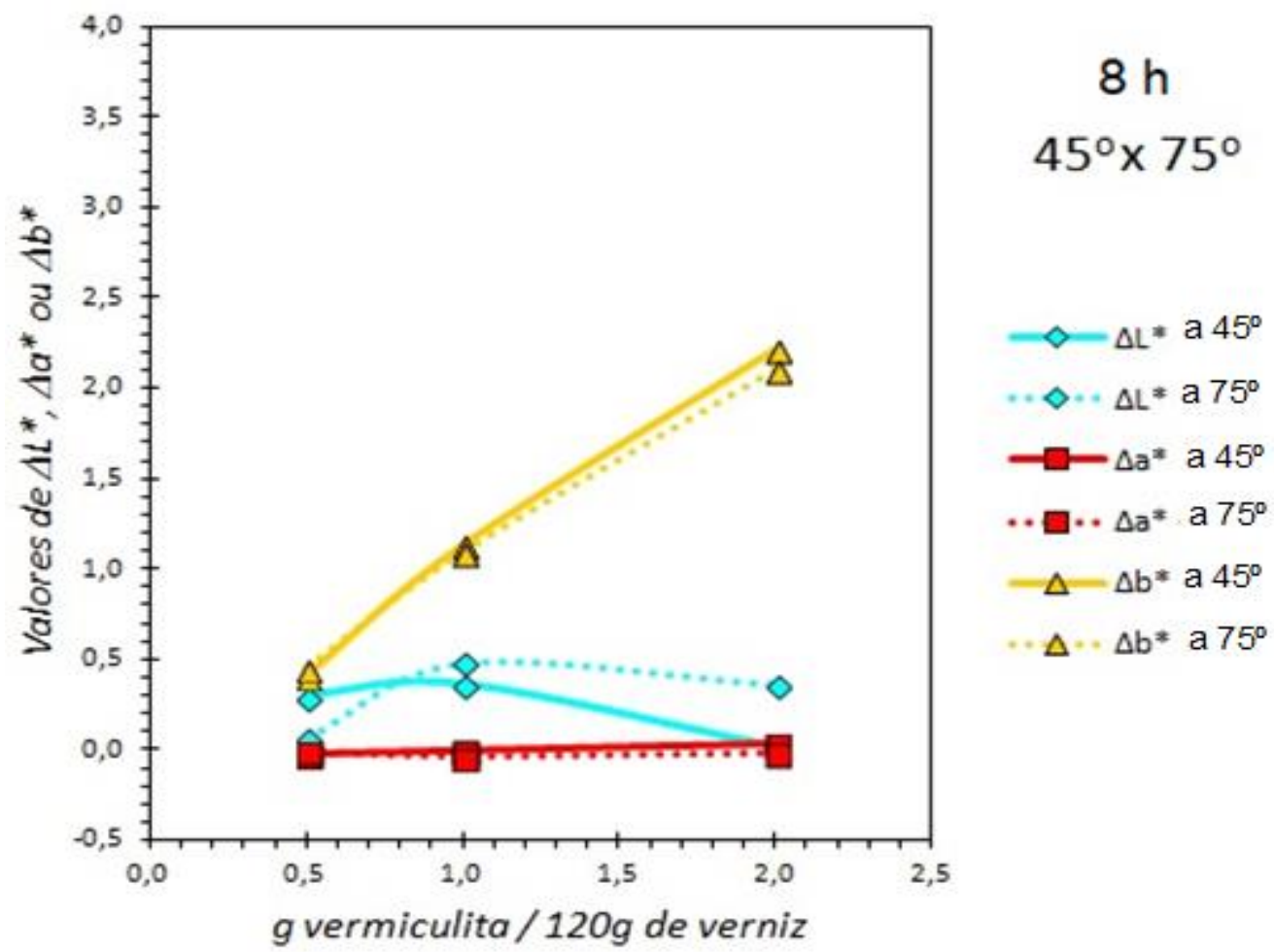

Figura 34 - Variação dos valores de $\Delta \mathrm{L}^{*}, \Delta \mathrm{a}^{*}$ e $\Delta \mathrm{b}^{*}$ em relação à quantidade de vermiculita processada para placas pintadas com tinta prata - leituras efetuadas nos ângulos de $45^{\circ}$ e $75^{\circ}$ de reflexão da luz. $8 \mathrm{~h}$ : tempo de moagem da vermiculita processada, correspondendo a tamanho médio de partícula de $195,5 \mathrm{~nm}$

Fonte: o Autor

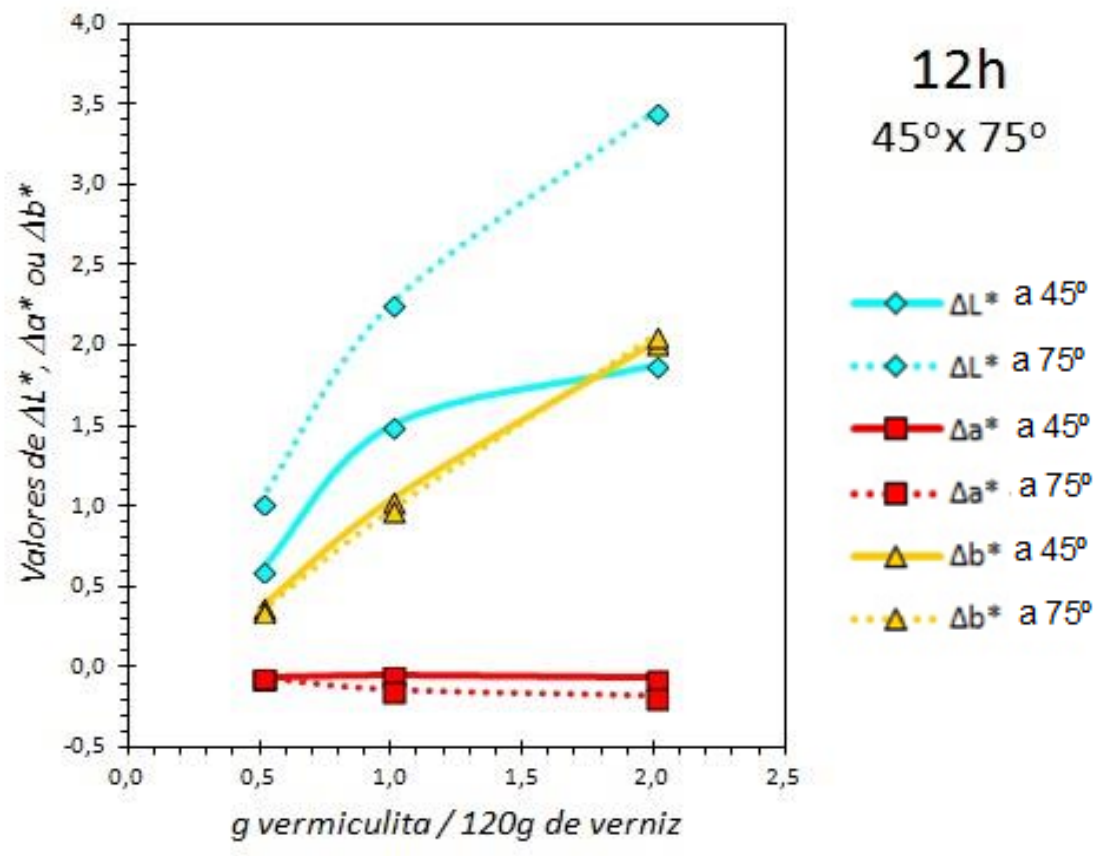

Figura 35 - Variação dos valores de $\Delta \mathrm{L}^{*}, \Delta \mathrm{a}^{*}$ e $\Delta \mathrm{b}^{*}$ em relação à quantidade de vermiculita processada para placas pintadas com tinta prata - leituras efetuadas nos ângulos de $45^{\circ}$ e $75^{\circ}$ de reflexão da luz. $12 \mathrm{~h}$ : tempo de moagem da vermiculita processada, correspondendo a tamanho médio de partícula de $170,9 \mathrm{~nm}$

Fonte: o Autor 
Análise dos resultados referentes ao verniz aplicado sobre tinta prata

Nas Figuras 32-35 são mostrados os valores de $\Delta \mathrm{a}^{*}$ próximos de zero, praticamente constantes. Isto indica que a tonalidade vermelha permaneceu praticamente constante e igual à tonalidade observada pela peça com verniz sem adição de vermiculita, independentemente da quantidade de vermiculita processada adicionada e do tamanho médio de partícula da vermiculita adicionada (Figuras 3235) e do ângulo de incidência da luz (Figuras 34-35).

Já os valores de $\Delta \mathrm{b}^{*}$, positivos e crescentes de acordo a quantidade de vermiculita processada adicionada independentemente do tamanho médio de partícula da vermiculita (Figuras 32-33), indicaram que o verniz ficou mais amarelado com a adição de vermiculita. Esse aumento na intensidade de cor amarela apareceu independentemente do ângulo de incidência da luz, uma vez que as curvas de $\Delta b^{*}$ obtidas a $45^{\circ}$ e a $75^{\circ}$ foram praticamente coincidentes (Figuras 34-35). A luminosidade apresentou grandes alterações com a quantidade de vermiculita processada adicionada com tamanho médio de partícula 170,9 nm (Figuras 32-33). Além disso, esse aumento de luminosidade observado foi dependente do ângulo de incidência da luz, sendo mais significativo quando a placa apresentou um ângulo de incidência igual a $75^{\circ}$ (Figuras 34-35). Esse aumento de luminosidade provavelmente foi devido à reflexão de luz nas partículas lamelares de vermiculita, que deveriam estar presentes em maior quantidade no material moído por um tempo maior (para uma mesma massa de material, um tamanho médio de partículas menor implicou em mais partículas presentes). 


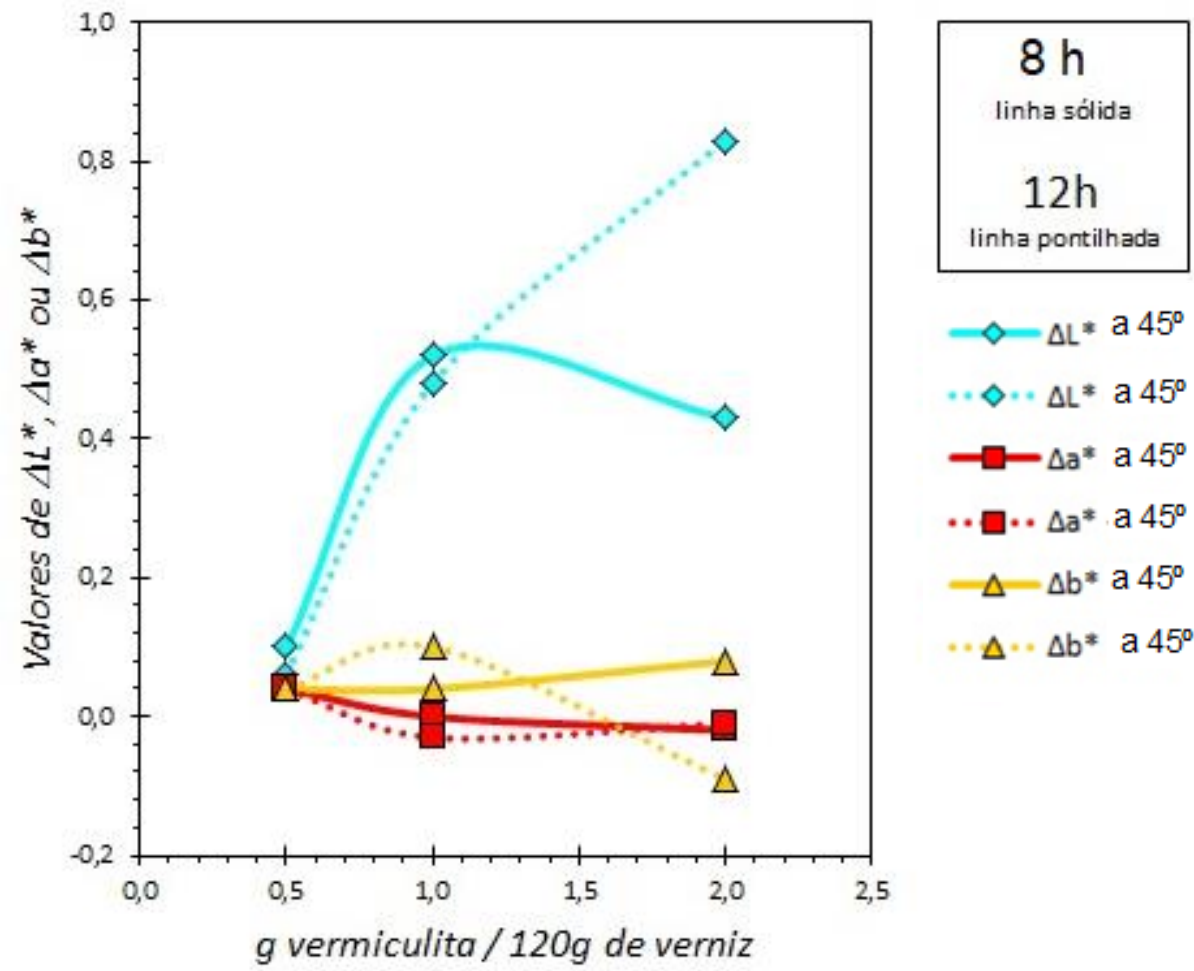

Figura 36 - Variação dos valores de $\Delta \mathrm{L}^{*}, \Delta \mathrm{a}^{*}$ e $\Delta \mathrm{b}^{*}$ em relação à quantidade de vermiculita processada para placas pintadas com tinta preta, leituras efetuadas no ângulo de $45^{\circ}$ de reflexão da luz. $8 \mathrm{~h}$ e $12 \mathrm{~h}$ : tempos de moagem da vermiculita processada, correspondendo respectivamente aos tamanhos médios de partícula de 195,5 nm e 170,9 nm Fonte: o Autor

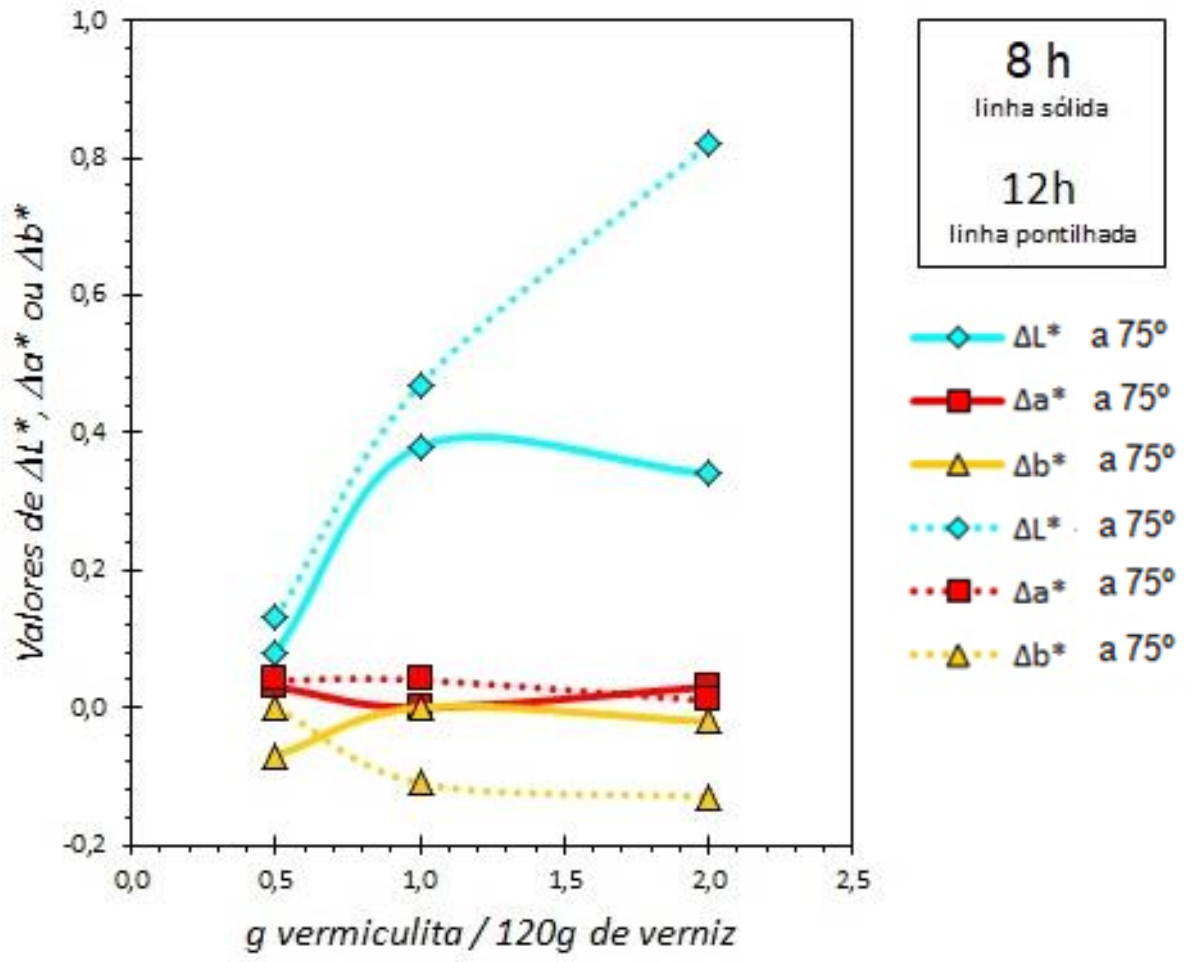

Figura 37 - Variação dos valores de $\Delta \mathrm{L}^{*}, \Delta \mathrm{a}^{*}$ e $\Delta \mathrm{b}^{*}$ em relação à quantidade de vermiculita processada para placas pintadas com tinta preta, leituras efetuadas no ângulo de $75^{\circ}$ de reflexão da luz. $8 \mathrm{~h}$ e $12 \mathrm{~h}$ : tempos de moagem da vermiculita processada, correspondendo respectivamente aos tamanhos médios de partícula de 195,5 nm e 170,9 nm - Fonte: o Autor 


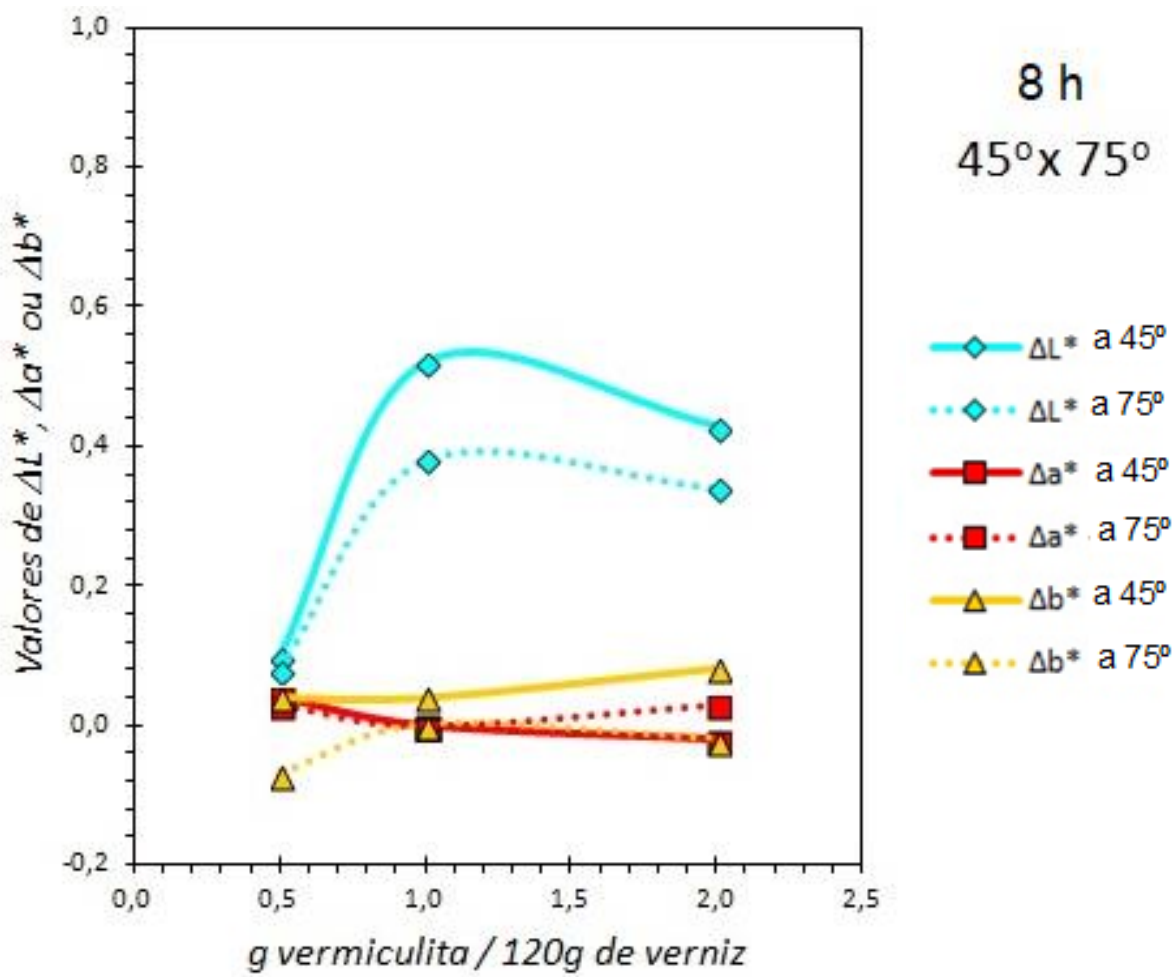

Figura 38 - Variação dos valores de $\Delta \mathrm{L}^{*}, \Delta \mathrm{a}^{*}$ e $\Delta \mathrm{b}^{*}$ em relação à quantidade de vermiculita processada para placas pintadas com tinta preta, leituras efetuadas nos ângulos de $45^{\circ}$ e $75^{\circ}$ de reflexão da luz. $8 \mathrm{~h}$ : tempo de moagem da vermiculita processada, correspondendo ao tamanho médio das partícula de $195,5 \mathrm{~nm}$ Fonte: o Autor
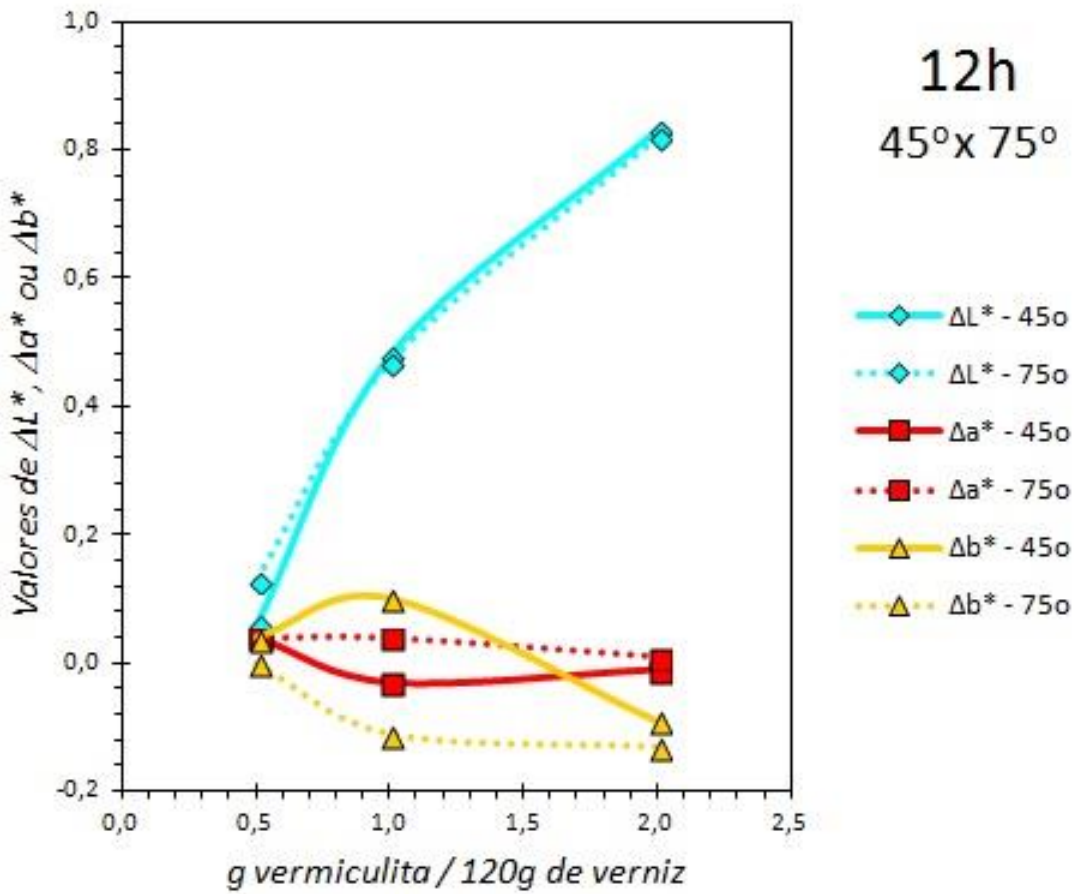

Figura 39 - Variação dos valores de $\Delta \mathrm{L}^{*}, \Delta \mathrm{a}^{*} \mathrm{e} \Delta \mathrm{b}^{*}$ em relação à quantidade de vermiculita processada para placas pintadas com tinta preta - leituras efetuadas nos ângulos de $45^{\circ}$ e $75^{\circ}$ de reflexão da luz. $12 \mathrm{~h}$ : tempo de moagem da vermiculita processada, correspondendo a tamanho médio de partícula de $170,9 \mathrm{~nm}$.

Fonte: o Autor 
Análise dos resultados referentes ao verniz aplicado sobre tinta preta

Nas Figuras 36-39 são mostrados os valores de $\Delta \mathrm{a}^{*}$ próximos de zero e com pequenas variações; isto indicou que a tonalidade vermelha permaneceu praticamente constante e igual à tonalidade observada na peça com verniz sem adição de vermiculita, independentemente da quantidade de vermiculita processada adicionada e do tamanho médio de partícula da vermiculita adicionada (Figuras 3637) e do ângulo de incidência da luz (Figuras 38-39). Ao contrário do que que foi observado nas placas onde o verniz foi aplicado sobre tinta prata, as placas onde o verniz foi aplicado sobre tinta preta também os valores de $\Delta \mathrm{b}^{*}$ variaram pouco (Figuras 32-33), indicando que o substrato preto dificultou a observação de eventuais variações de cor que poderiam ser proporcionadas pela adição da vermiculita processada. A variação mais significativa foi observada na série de vernizes contendo vermiculita com tamanho médio de partícula de 170,9 nm observada com incidência de luz a $75^{\circ}$, que apresentou variação de $\Delta b^{*}$ negativa e com valores decrescentes com o aumento da adição de vermiculita, indicando o desenvolvimento de uma fraca coloração na direção para o verde (Figuras 37 e 39).

Nas placas com substrato preto, a luminosidade apresentou alterações significativas, seja com a quantidade de vermiculita processada adicionada, seja com o tamanho médio de partícula da vermiculita (Figuras 36-37). O aumento da quantidade de vermiculita processada com o tamanho médio de partícula de 170,9 nm levou a um aumento monotônico no valor de $\Delta \mathrm{L}^{*}$, o que não ocorreu no caso das partículas de tamanho médio de $195,5 \mathrm{~nm}$, cujo valor de $\Delta \mathrm{L}^{*}$ apresentou um aumento de luminosidade com o aumento inicial da concentração adicionada, para se estabilizar com um aumento subsequente. Além disso, esse aumento de luminosidade observado foi dependente do ângulo de incidência da luz no caso das partículas com tamanho médio de 195,5 nm (sendo mais significativo quando a placa foi observada com ângulo de incidência igual a 45ำ (Figura 38), sendo praticamente independente do ângulo de incidência da luz no caso das partículas menores de diâmetro médio de 170,9 nm (Figura 39). A mesma explicação proposta para a observação a respeito da luminosidade no caso dos vernizes aplicados sobre tinta prata valeria para os vernizes aplicados sobre tinta preta. 


\section{4 - Desenvolvimento de dureza superficial nos filmes de vernizes contendo vermiculita processada}

Os resultados de avaliação da dureza superficial do verniz, obtidos segundo a norma ASTM D4366-94 no equipamento de Dureza König, são apresentados na Tabela 21.

Tabela 21 - Resultados da dureza do verniz determinada pelo pêndulo König (norma ASTM D 436694)

\begin{tabular}{|c|c|c|c|c|c|}
\hline \multirow{2}{*}{$\begin{array}{l}\text { Dimensão média } \\
\text { das partículas de } \\
\text { vermiculita } \\
\text { processada } \\
\text { adicionadas ao } \\
\text { sistema do verniz } \\
\text { com endurecedor }\end{array}$} & \multirow{2}{*}{$\begin{array}{l}\% \text { de vermiculita } \\
\text { processada sobre } \\
100 \text { g de matéria não } \\
\text { volátil do sistema } \\
\text { verniz endurecedor }\end{array}$} & \multicolumn{4}{|c|}{$\begin{array}{c}\text { Dureza do verniz realizada pelo pêndulo de König } \\
\text { após envelhecimento, (tempo em horas), à } \\
\text { temperatura média de } 25^{\circ} \mathrm{C} \text { sob umidade relativa do } \\
\text { ar entre } 60 \% \text { e } 80 \% \text {. } \\
\end{array}$} \\
\hline & & $24 \mathrm{~h}$ & $48 \mathrm{~h}$ & $144 \mathrm{~h}$ & $168 \mathrm{~h}$ \\
\hline - & $0 \%$ & 105,0 & 109,2 & 112,0 & 113,4 \\
\hline \multirow{3}{*}{$170,9 \mathrm{~nm}$} & $0,87 \%$ & 159,6 & 173,6 & 189,0 & 245,0 \\
\hline & $1,74 \%$ & 149,8 & 162,4 & 179,2 & 184,8 \\
\hline & $3,48 \%$ & 145,6 & 161,0 & 176,4 & 182,0 \\
\hline \multirow{3}{*}{$195,5 \mathrm{~nm}$} & $0,87 \%$ & 100,8 & 109,2 & 110,6 & 116,2 \\
\hline & $1,74 \%$ & 159,6 & 173,6 & 176,4 & 186,2 \\
\hline & $3,48 \%$ & 147,0 & 163,8 & 175,0 & 170,8 \\
\hline
\end{tabular}

Fonte: Tabela gerada pelo Autor a partir de dados obtidos nos laboratórios da Axalta Coating Corporate

Nas Figuras 40 e 41 é mostrada a evolução da dureza König com o tempo de envelhecimento para os filmes produzidos com adição de vermiculita processada com diâmetros médios de partículas iguais, respectivamente, adição a 195,5 nm e $170,9 \mathrm{~nm}$.

Em todos os filmes estudados, sem e com adição de vermiculita processada, foi observada a tendência ao aumento da dureza com o tempo de envelhecimento do filme, conforme esperado em vernizes uretânicos. 


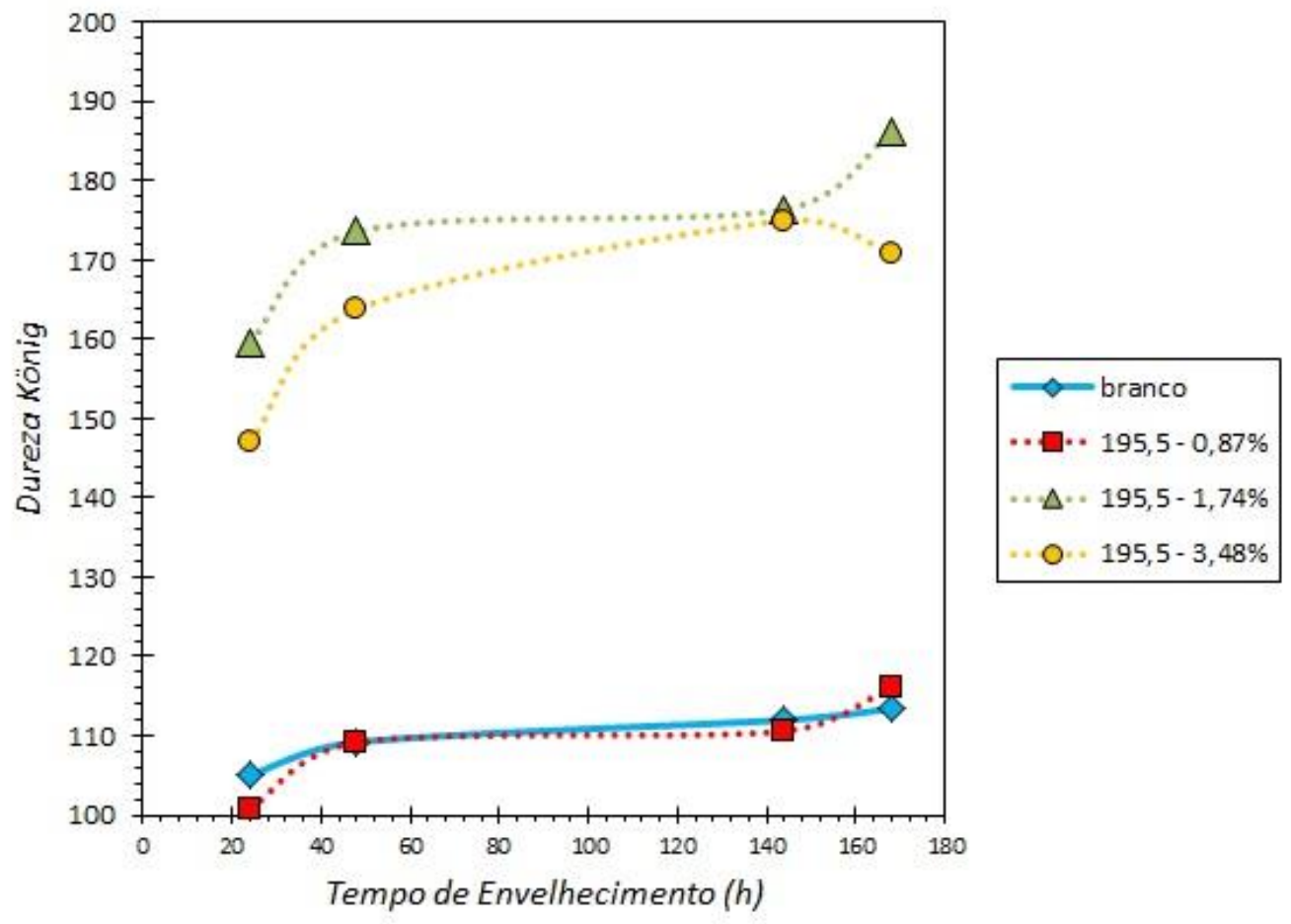

Figura 40 - Evolução da dureza König com o tempo de envelhecimento para filmes produzidos com adição de vermiculita processada com diâmetro médio de partícula igual a 195,5 nm, em comparação com a evolução da dureza do filme sem adição de vermiculita (branco) Fonte: o Autor

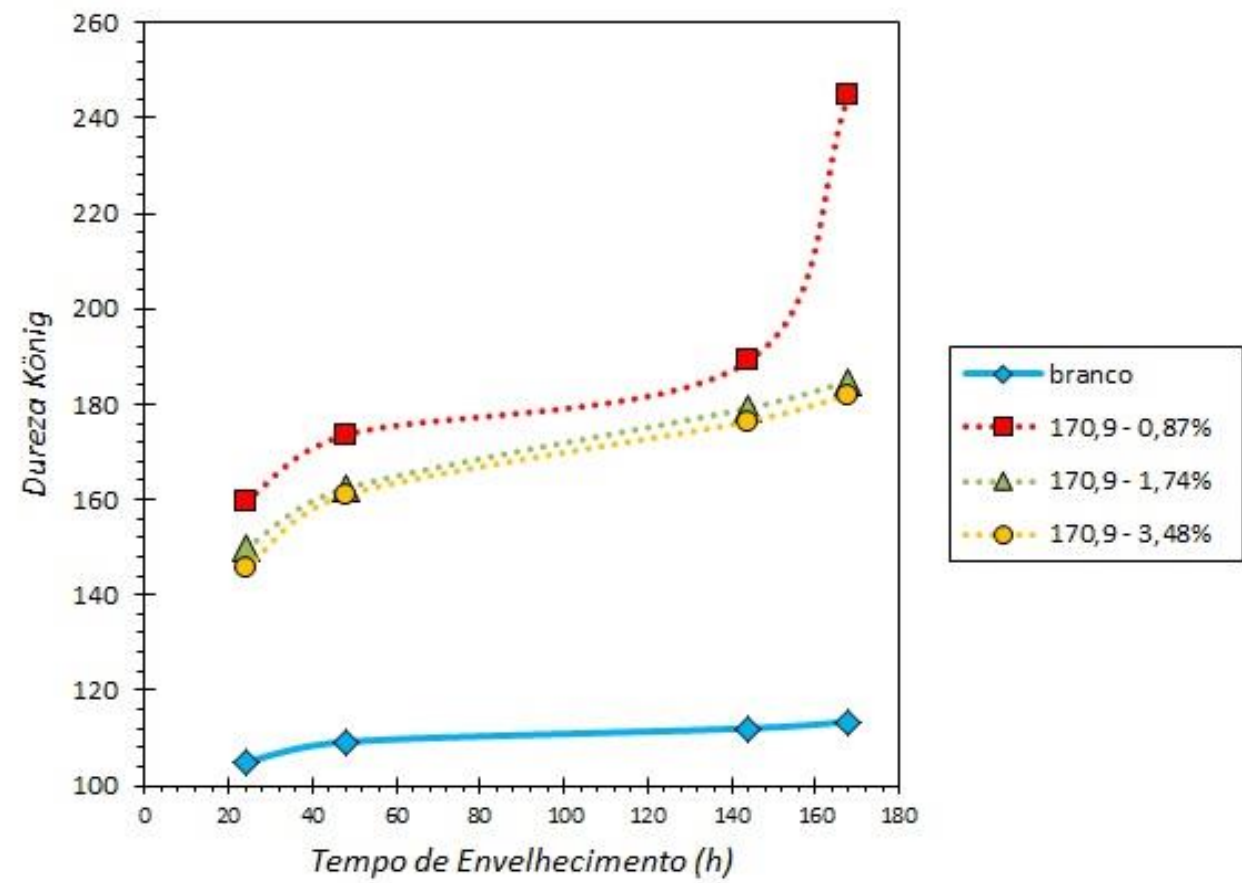

Figura 41 - Evolução da dureza König com o tempo de envelhecimento para filmes produzidos com adição de vermiculita processada com diâmetro médio de partícula igual a 170,9 nm, em comparação com a evolução da dureza do filme sem adição de vermiculita (branco)

Fonte: o Autor 
A adição de partículas de vermiculita processada com diâmetro médio igual a 195,5 nm levou a um significativo aumento de dureza em relação à dureza do filme de verniz sem adição em duas das três concentrações estudadas (1,74 \% e 3,48 \%) (Figura 40). A evolução com o tempo de envelhecimento nesses dois casos foi similar.

Para a adição de vermiculita em menor concentração $(0,87 \%)$ isso não aconteceu, e a evolução da dureza com o tempo de envelhecimento do filme de verniz com essa adição foi praticamente indistinguível da evolução do filme de verniz sem adição. Não houve uma explicação para essa observação a não ser a de um erro experimental na preparação dessa amostra de verniz.

Já as adições de partículas de vermiculita processada com diâmetro médio igual a 170,9 nm levaram a significativos aumentos de dureza em relação à dureza do filme de verniz sem adição em todas as três concentrações estudadas (Figura 41). A amostra que apresentou as maiores durezas em todos os tempos de envelhecimento analisados foi aquela que tinha a menor concentração de vermiculita adicionada; essa preparação mostrou, ainda um valor elevado de dureza para o filme envelhecido por 168h. Também não houve uma explicação para a elevação de dureza observada nesse filme.

Numa tentativa de auxiliar a intepretação dessas observações, as Figuras 4244 mostraram as comparações das evoluções da dureza König (dados de dureza colocados na mesma escala) com o tempo de envelhecimento para filmes produzidos com adição das mesmas porcentagens de vermiculita de tamanhos médios distintos. Na Figura 42 são mostrados os resultados da evolução das durezas dos filmes de verniz com adição de $0,87 \%$ de vermiculita com os dois tamanhos médios. A diferença entre essas amostras foi muito grande, mas esses foram os dois casos para os quais não houve explicação para os comportamentos, tanto para a ausência de efeito no caso da vermiculita de diâmetro médio igual a 195,5 nm, quanto para o aumento de dureza observado no maior tempo de envelhecimento do filme com a vermiculita de diâmetro médio de $170,9 \mathrm{~nm}$. 


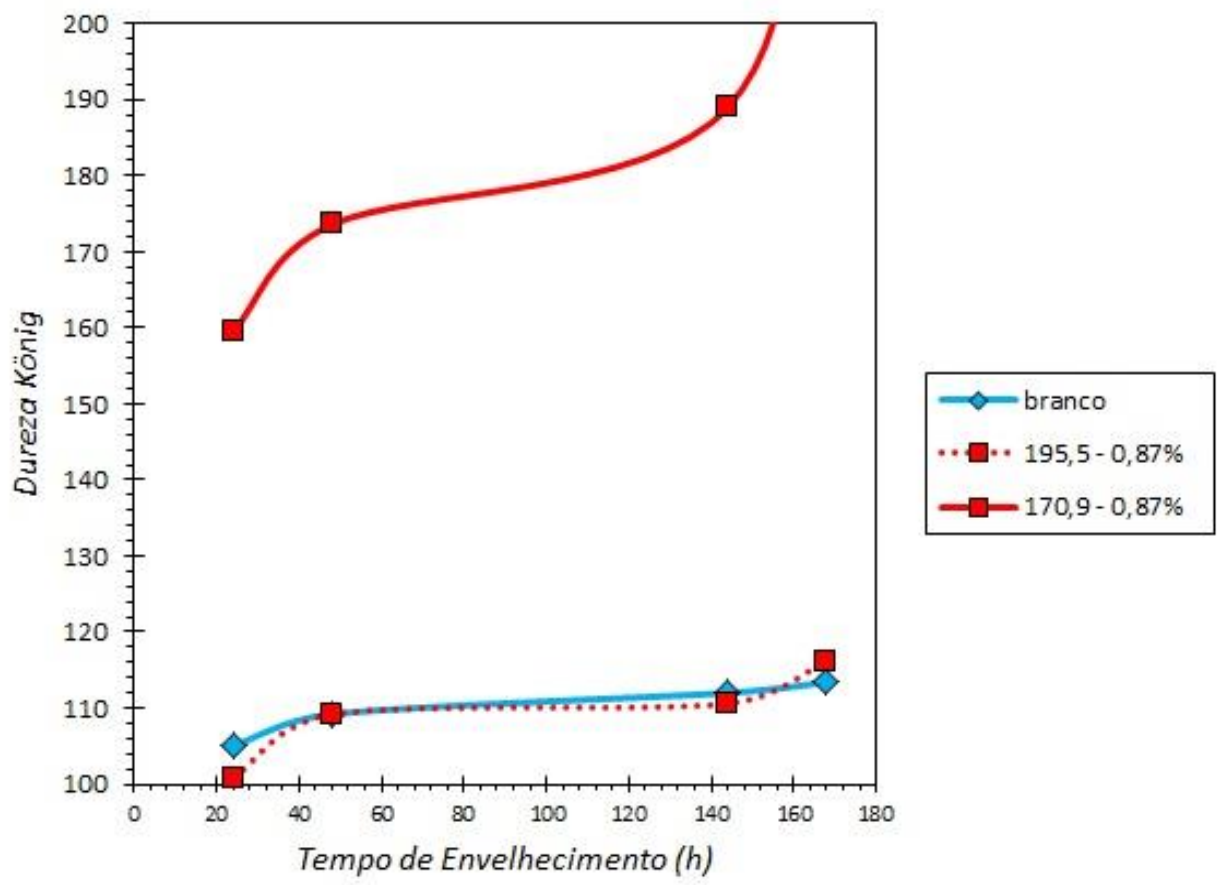

Figura 42 - Evolução da dureza König com o tempo de envelhecimento para filmes produzidos com adição de 0,87 \% de vermiculita processada com diâmetros médios de partículas iguais a 170,9 nm e $195,5 \mathrm{~nm}$, em comparação com a evolução da dureza do filme sem adição de vermiculita (branco) Fonte: o Autor

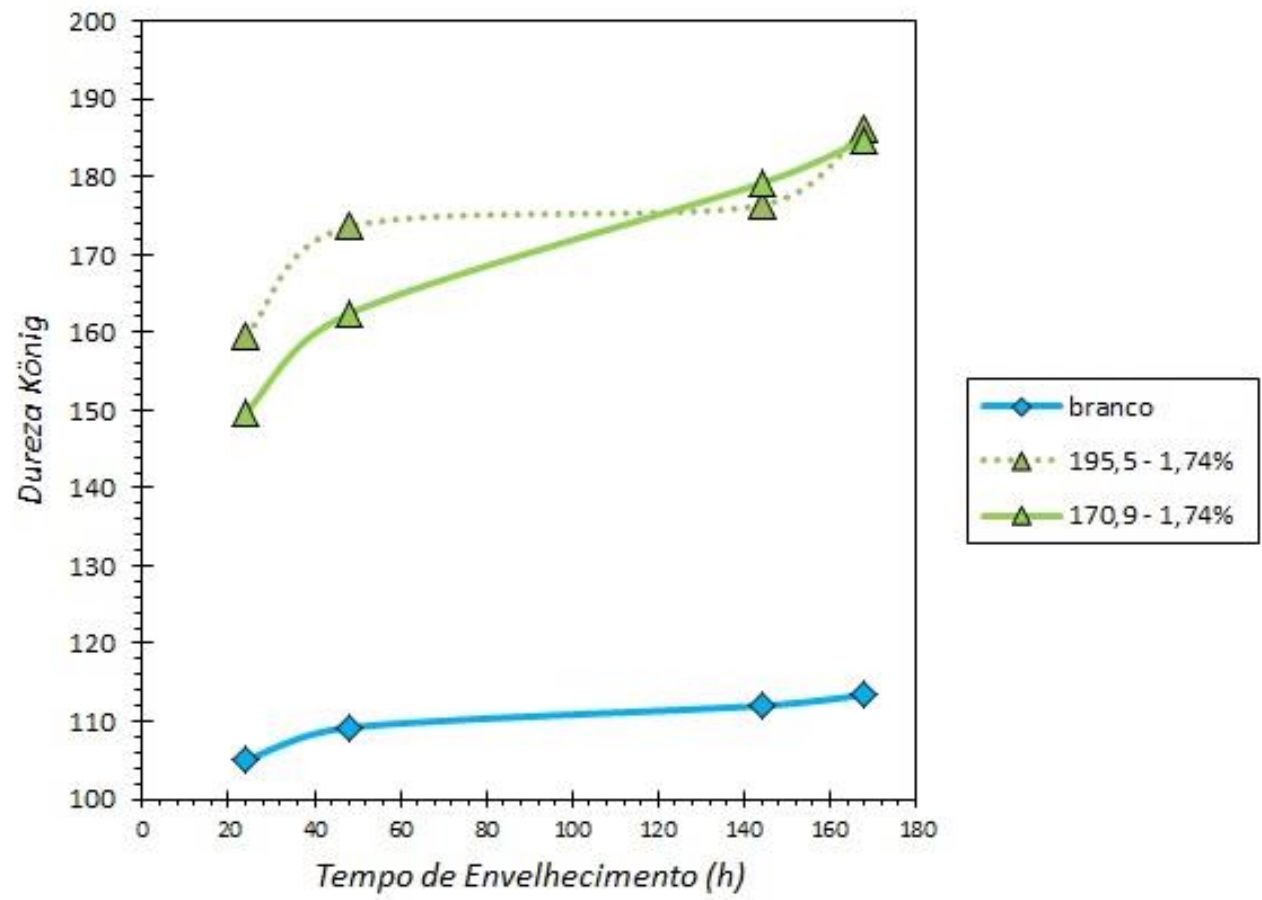

Figura 43 - Evolução da dureza König com o tempo de envelhecimento para filmes produzidos com adição de 1,74 \% de vermiculita processada com diâmetros médios de partículas iguais a 170,9 nm e $195,5 \mathrm{~nm}$, em comparação com a evolução da dureza do filme sem adição de vermiculita (branco) Fonte: o Autor 


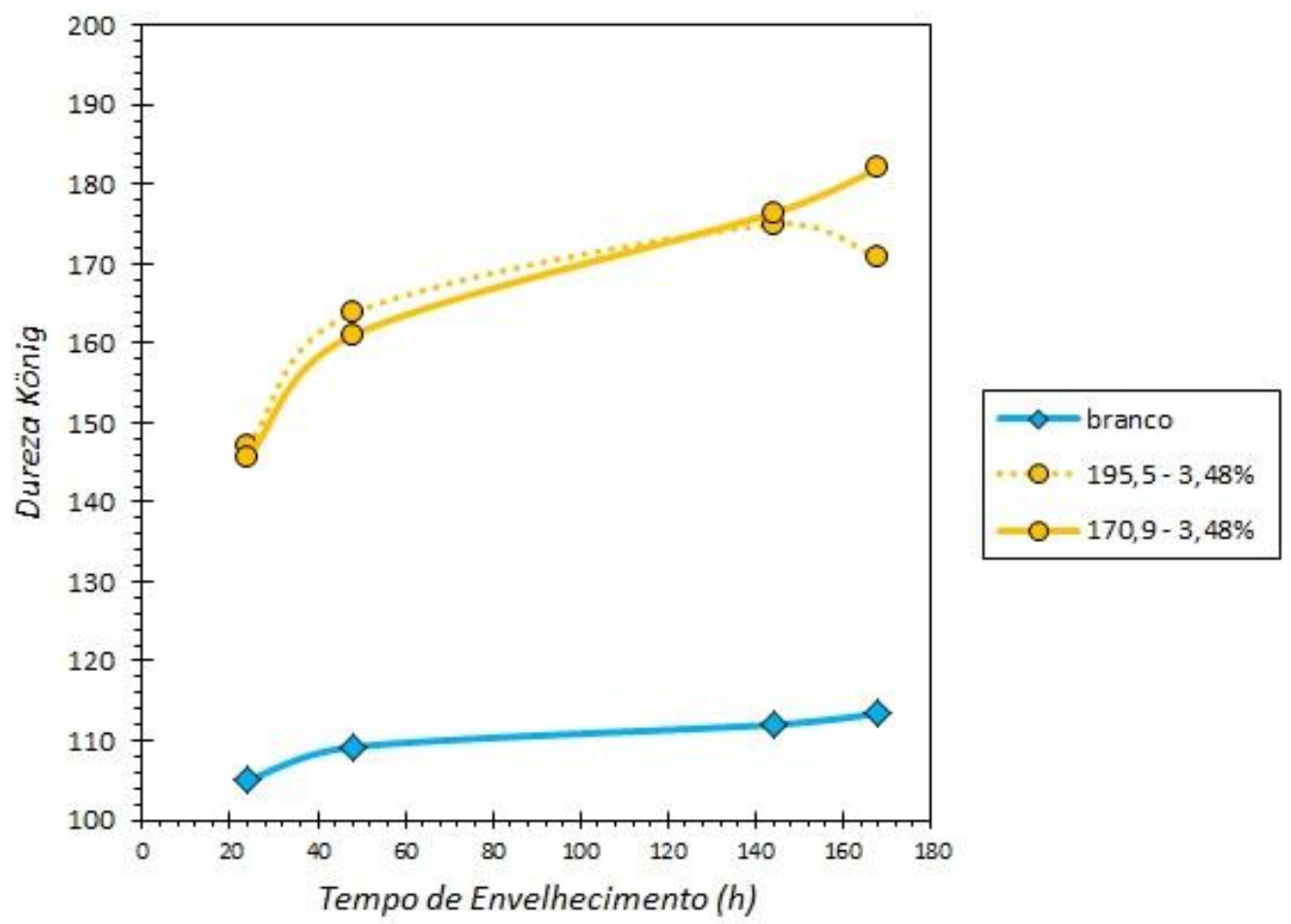

Figura 44 - Evolução da dureza König com o tempo de envelhecimento para filmes produzidos com adição de $3,48 \%$ de vermiculita processada com diâmetros médios de partículas iguais a 170,9 nm e $195,5 \mathrm{~nm}$, em comparação com a evolução da dureza do filme sem adição de vermiculita (branco) Fonte: o Autor

Nas Figuras 43-44 são mostrados os resultados das evoluções das durezas dos filmes de verniz com adição, respectivamente, de $1,74 \%$ e $3,48 \%$ de vermiculita processada com os dois diferentes tamanhos médios, de 195,5 $\mathrm{nm}$ e de $170,9 \mathrm{~nm}$. Na faixa de concentrações estudada, os valores de dureza e suas evoluções com o tempo de envelhecimento foram similares, aparentemente não importando o tamanho médio de partículas das vermiculitas processadas.

Em resumo, foi observado que a presença de partículas de vermiculita processada nos vernizes leva a um significativo aumento em sua dureza (no mínimo, de $45 \%$ ), sendo mantida em linhas gerais a tendência de elevação da dureza dos filmes com o tempo de envelhecimento. Não foi possível determinar e relacionar de forma clara as diferenças de comportamento relacionadas ao tamanho médio das partículas de vermiculita ao tempo de envelhecimento. A presença de vermiculita nos sistemas uretânicos causou aumento da dureza nos filmes e, esta elevação da dureza pode ser devido a um direcionamento prioritário de formação de ligações 
químicas mais estáveis na estrutura resinosa criando reticulações mais rígidas no filme formado.

\section{5 - Estudo do efeito da adição de vermiculita processada na aceleração da reação em sistemas uretânico de dois componentes}

O sistema de dois componentes para vernizes uretânicos se baseia na reatividade entre as resinas após a mistura dos componentes. Essa é a razão pela qual eles são fornecidos no mercado em embalagens separadas.

A reação ocorre como representada na Figura 1: reação entre os grupos funcionais $(-\mathrm{N}=\mathrm{C}=\mathrm{O})$ contidos nas moléculas do componente 2 e grupos hidroxila $(-\mathrm{OH})$ presentes nas moléculas de resina do componente 1.

As composições empregadas nos ensaios de avaliação de aceleração da reação foram apresentadas anteriormente nesta Tese, nas Tabelas 7 a 10.

Os resultados de viscosidade, empregados na avaliação da aceleração reacional promovida pela presença de vermiculita processada em sistema uretânicos de dois componentes, são apresentados nas Tabelas 22 e 23. Na Tabela 22 são mostrados os resultados relativos aos materiais com adição de vermiculita processada sem tratamento térmico a $1000^{\circ} \mathrm{C}$, e na Tabela 23 são mostrados os resultados relativos a materiais com adição de vermiculita processada com tratamento térmico a $1000^{\circ} \mathrm{C}$.

Observação: Como mencionado anteriormente nos resultados de difração de raios $X$, esse material, apesar de ter sido chamado ao longo da Tese de vermiculita processada calcinada a $1000^{\circ} \mathrm{C}$, na verdade é constituído essencialmente de enstatita associada a uma fase amorfa. Para manter a nomenclatura empregada, esse material continuará a ser chamado de vermiculita processada calcinada a $1000^{\circ} \mathrm{C}$. 
Tabela 22 - Viscosidades obtidas no Copo Ford 4 a $25^{\circ} \mathrm{C}$ para sistemas contendo vermiculita processada (tamanhos médios de partículas iguais a 195,5 e 170,9 nm) sem calcinação a $1000^{\circ} \mathrm{C}$

\begin{tabular}{|c|c|c|c|c|c|c|c|c|c|c|c|}
\hline \multirow[b]{2}{*}{ conc. $\rightarrow$} & \multirow[b]{2}{*}{0} & \multicolumn{5}{|c|}{ tamanho médio = $195,5 \mathrm{~nm}$} & \multicolumn{5}{|c|}{ tamanho médio $=170,9 \mathrm{~nm}$} \\
\hline & & 0,125 & 0,25 & 0,50 & 1,00 & 2,00 & 0,125 & 0,25 & 0,50 & 1,00 & 2,00 \\
\hline $\begin{array}{c}\text { Tempo } \\
\text { (h) }\end{array}$ & $\begin{array}{l}\text { PVO- } \\
\text { SM }\end{array}$ & $\begin{array}{l}\text { PV1- } \\
\text { SM }\end{array}$ & $\begin{array}{l}\text { PV2- } \\
\text { SM }\end{array}$ & $\begin{array}{l}\text { PV3- } \\
\text { SM }\end{array}$ & $\begin{array}{l}\text { PV4- } \\
\text { SM }\end{array}$ & $\begin{array}{l}\text { PV5- } \\
\text { SM }\end{array}$ & $\begin{array}{l}\text { PV6- } \\
\text { SM }\end{array}$ & $\begin{array}{l}\text { PV7- } \\
\text { SM }\end{array}$ & $\begin{array}{l}\text { PV8- } \\
\text { SM }\end{array}$ & $\begin{array}{l}\text { PV9- } \\
\text { SM }\end{array}$ & $\begin{array}{c}\text { PV10- } \\
\text { SM }\end{array}$ \\
\hline 0 & 20 & 21 & 22 & 23 & 24 & 24 & 18 & 18 & 18 & 18 & 18 \\
\hline 1 & 30 & 30 & 30 & 31 & 31 & 31 & 20 & 20 & 20 & 20 & 20 \\
\hline 2 & 34 & 31 & 31 & 31 & 32 & 33 & 22 & 21 & 21 & 22 & 22 \\
\hline 3 & 35 & 34 & 34 & 34 & 35 & 35 & 24 & 24 & 24 & 24 & 24 \\
\hline 4 & 42 & 39 & 39 & 39 & 39 & 40 & 28 & 28 & 27 & 28 & 28 \\
\hline 5 & 52 & 48 & 49 & 49 & 50 & 50 & 37 & 40 & 37 & 36 & 37 \\
\hline 6 & 66 & 64 & 64 & 66 & 77 & 80 & 66 & 81 & 63 & 61 & 64 \\
\hline 7 & 114 & 107 & 112 & 114 & 119 & 123 & Gel & Gel & Gel & Gel & Gel \\
\hline
\end{tabular}

Fonte: O Autor

Tabela 23 - Viscosidades obtidas no Copo Ford 4 a $25^{\circ} \mathrm{C}$ para sistemas contendo vermiculita processada (diâmetros médios de partículas iguais a 195,5 e 170,9 nm) com calcinação a $1000^{\circ} \mathrm{C}$.

\begin{tabular}{|c|c|c|c|c|c|c|c|c|c|c|c|}
\hline \multirow[b]{2}{*}{ conc. $\rightarrow$} & \multirow[b]{2}{*}{0} & \multicolumn{5}{|c|}{ tamanho médio $=195,5 \mathrm{~nm}$} & \multicolumn{5}{|c|}{ tamanho médio $=170,9 \mathrm{~nm}$} \\
\hline & & 0,125 & 0,25 & 0,50 & 1,00 & 2,00 & 0,125 & 0,25 & 0,50 & 1,00 & 2,00 \\
\hline $\begin{array}{c}\text { Tempo } \\
\text { (h) }\end{array}$ & $\begin{array}{l}\text { PVO- } \\
\text { CM }\end{array}$ & $\begin{array}{l}\text { PV1- } \\
\text { CM }\end{array}$ & $\begin{array}{l}\text { PV2- } \\
\text { CM }\end{array}$ & $\begin{array}{l}\text { PV3- } \\
\text { CM }\end{array}$ & $\begin{array}{l}\text { PV4- } \\
\text { CM }\end{array}$ & $\begin{array}{l}\text { PV5- } \\
\text { CM }\end{array}$ & $\begin{array}{l}\text { PV6- } \\
\text { CM }\end{array}$ & $\begin{array}{l}\text { PV7- } \\
\text { CM }\end{array}$ & $\begin{array}{l}\text { PV8- } \\
\text { CM }\end{array}$ & $\begin{array}{c}\text { PV9- } \\
\text { CM }\end{array}$ & $\begin{array}{c}\text { PV10- } \\
\text { CM }\end{array}$ \\
\hline 0 & 20 & 20 & 19 & 19 & 20 & 20 & 20 & 19 & 19 & 20 & 20 \\
\hline 1 & 30 & 22 & 22 & 21 & 21 & 21 & 25 & 26 & 28 & 35 & 42 \\
\hline 2 & 33 & 23 & 23 & 22 & 22 & 23 & 32 & 32 & 35 & 42 & 60 \\
\hline 3 & 35 & 24 & 23 & 23 & 24 & 23 & 60 & 62 & 60 & 68 & 109 \\
\hline 4 & 40 & 27 & 27 & 27 & 27 & 28 & 80 & 78 & 85 & 95 & 130 \\
\hline 5 & 51 & 36 & 36 & 35 & 37 & 39 & Gel & Gel & Gel & Gel & Gel \\
\hline 6 & 65 & 45 & 46 & 46 & 48 & 54 & Gel & Gel & Gel & Gel & Gel \\
\hline 7 & 112 & 84 & 91 & 110 & 110 & 181 & Gel & Gel & Gel & Gel & Gel \\
\hline
\end{tabular}

Fonte: O Autor

\section{Legenda para ambas as Tabelas}

- Tempo : tempo decorrido após a mistura inicial (h)

- Conc. : concentração da vermiculita processada adicionada, dada em g de vermiculita / $120 \mathrm{~g}$ resina seca (verniz + endurecedor)

- Gel : a mistura gelificou após decorrido o tempo de mistura indicado, não sendo possível a determinação da viscosidade pelo Copo Ford 4

- CM : vermiculita calcinada a $1000^{\circ} \mathrm{C}$

- $S M$ : vermiculita não calcinada a $1000^{\circ} \mathrm{C}$

- $P V$ : prova 
$\mathrm{Na}$ Figura 45 são mostradas as curvas para as viscosidades, obtidas no viscosímetro Copo Ford 4, em função do tempo decorrido após mistura dos reagentes e diferentes concentrações de vermiculita processada com tamanho médio de partículas; $195,5 \mathrm{~nm}$ (sem e com calcinação a 1000C).

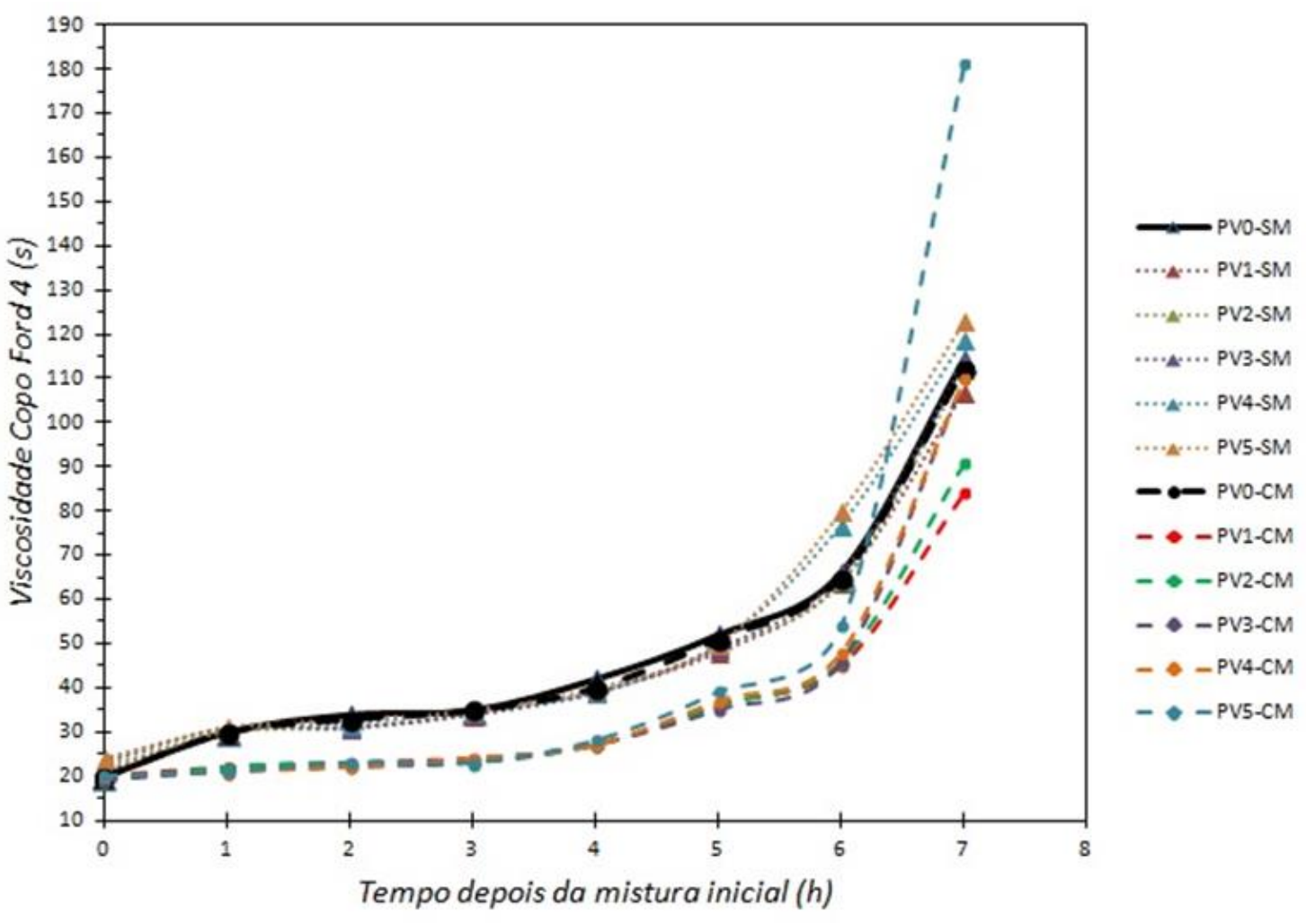

Figura 45 - Evolução da viscosidade determinada pelo método Copo Ford 4 com o tempo de reação para os sistemas contendo vermiculita processada de tamanho médio de partículas de 195,5 nm, sem calcinação a $1000^{\circ} \mathrm{C}$ (amostras PVi-SM, linha pontilhada) e após calcinação a $1000^{\circ} \mathrm{C}$ (amostra PVi$\mathrm{CM}$, linha tracejada)

Fonte: o Autor

A partir desses resultados, mostrados na Figura 45, pode ser notado que até 5h, após a mistura inicial, não existe um efeito observável da adição da vermiculita processada não calcinada com diâmetro médio de195,5 nm sobre a evolução da viscosidade em função do tempo. A evolução da viscosidade foi praticamente idêntica para os sistemas com e sem adição de vermiculita processada. Após 6h e $7 \mathrm{~h}$ de reação, para as duas maiores concentrações de vermiculita, observou-se um pequeno aumento de viscosidade em relação à amostra sem adição de vermiculita.

Para visualizar esta variação de viscosidade de forma mais clara, os mesmos dados são mostrados na Figura 46, fixando os tempos de reação e apresentando a variação da viscosidade em função da concentração de vermiculita adicionada. 
Nesta Figura 46 ficou evidente: que a viscosidade aumentou com o tempo de reação para todas as misturas produzidas. A viscosidade é praticamente independente da concentração de vermiculita adicionada até tempos de reação iguais a $5 \mathrm{~h}$. A viscosidade apresentou um ligeiro aumento com a concentração de vermiculita para tempos iguais ou superiores a $6 \mathrm{~h}$ de reação.

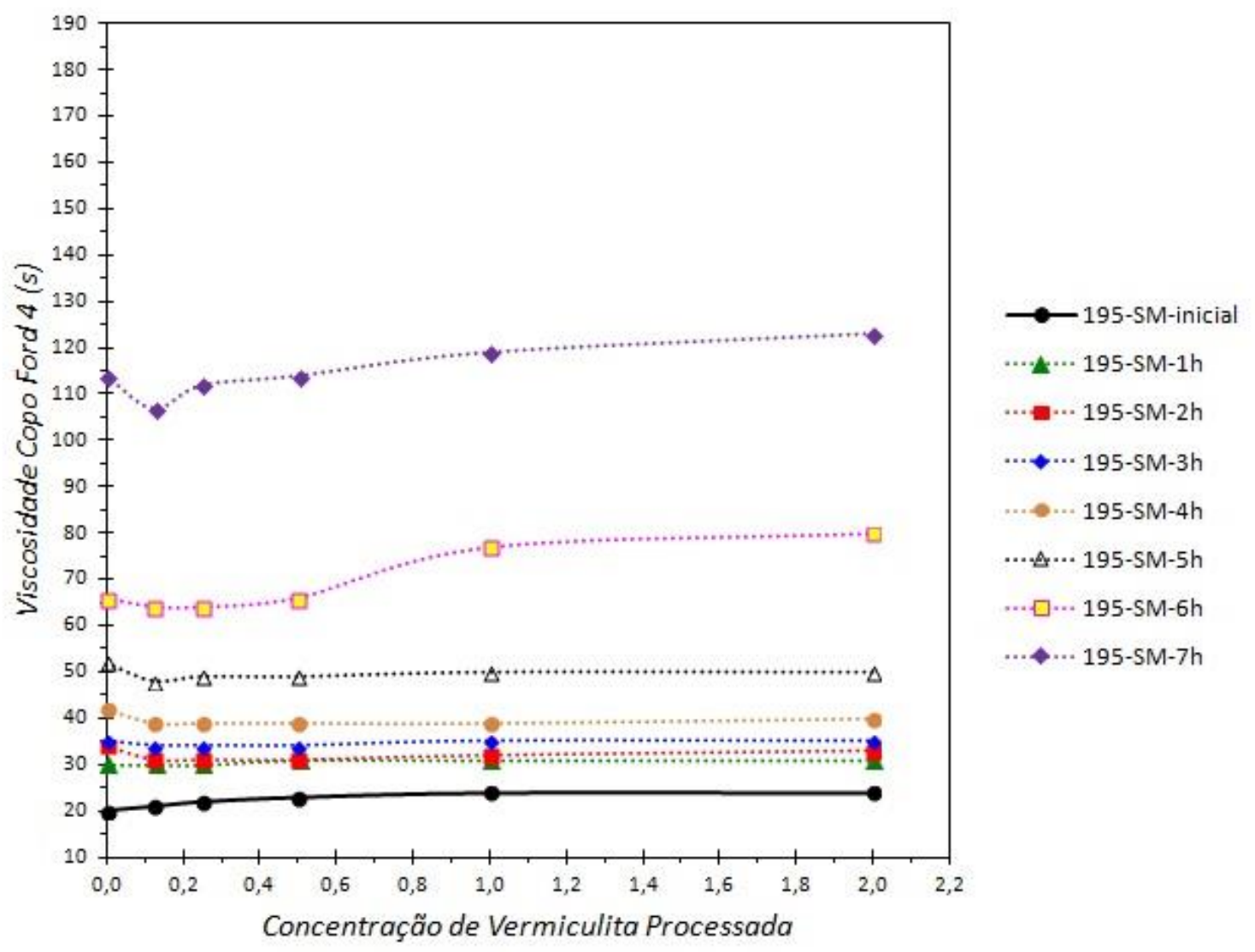

Figura 46 - Evolução da viscosidade determinada pelo método Copo Ford $4 \mathrm{com}$ a concentração de vermiculita (dada em g de vermiculita / $120 \mathrm{~g}$ de (verniz + endurecedor) para sistemas contendo vermiculita processada de tamanho médio de partículas de $195,5 \mathrm{~nm}$, sem calcinação a $1000^{\circ} \mathrm{C}$, para diferentes tempos de reação

Fonte: o Autor

Também a partir dos resultados mostrados na Figura 45, observou-se que as viscosidades das misturas contendo vermiculita processada com diâmetro médio de $195,5 \mathrm{~nm}$ e calcinada a $1000^{\circ} \mathrm{C}$ foram sempre inferiores às viscosidades da mistura sem adição de vermiculita até o tempo de $6 \mathrm{~h}$ de reação. Decorridas $7 \mathrm{~h}$ de reação, os valores de viscosidade aumentaram da mesma forma que ocorreu com a viscosidade da mistura sem adição de vermiculita. Duas amostras (de concentrações de $0,50 \mathrm{~g}$ e de $1,00 \mathrm{~g} / 120 \mathrm{~g}$ de resina + endurecedor) atingiram praticamente $\mathrm{o}$ 
mesmo valor de viscosidade da mistura sem adição. A amostra de maior concentração de vermiculita, atingiu um valor de viscosidade cerca de $80 \%$ maior do que aquela do verniz sem adição de vermiculita.

As variações dos valores das viscosidades em relação às concentrações de vermiculita processada e calcinada a $1000^{\circ} \mathrm{C}$ para tempos de reação fixos pode ser observada de forma mais clara na Figura 47.

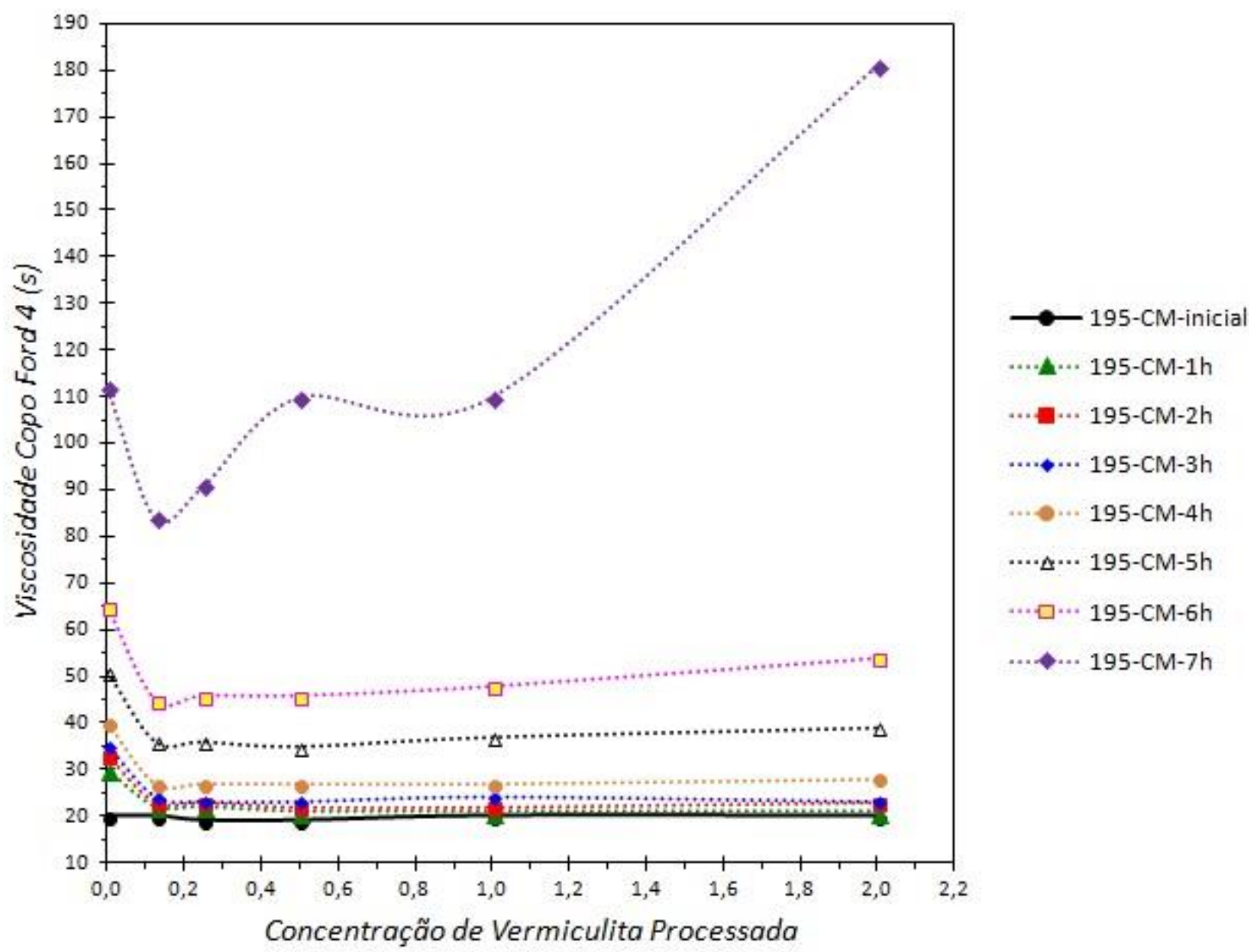

Figura 47 - Evolução da viscosidade determinada pelo método Copo Ford $4 \mathrm{com}$ a concentração de vermiculita (dada em g de vermiculita / $120 \mathrm{~g}$ de (verniz + endurecedor) para sistemas contendo vermiculita processada de tamanho médio de partículas de $195,5 \mathrm{~nm}$, após calcinação a $1000^{\circ} \mathrm{C}$, para diferentes tempos de reação

Fonte: o Autor

No estado atual dos estudos que foram feitos para a elaboração da presente Tese, não houve uma explicação clara para os comportamentos das misturas contendo vermiculita processada com diâmetro médio de partícula de 195,5 nm.

Na Figura 48 são mostrados a evolução da viscosidade, determinada no Copo Ford 4, em função do tempo de reação para diferentes concentrações de vermiculita 
processada de tamanho médio de partícula de 170,9 nm (sem e com calcinação a $1000^{\circ} \mathrm{C}$ ) adicionada às misturas.

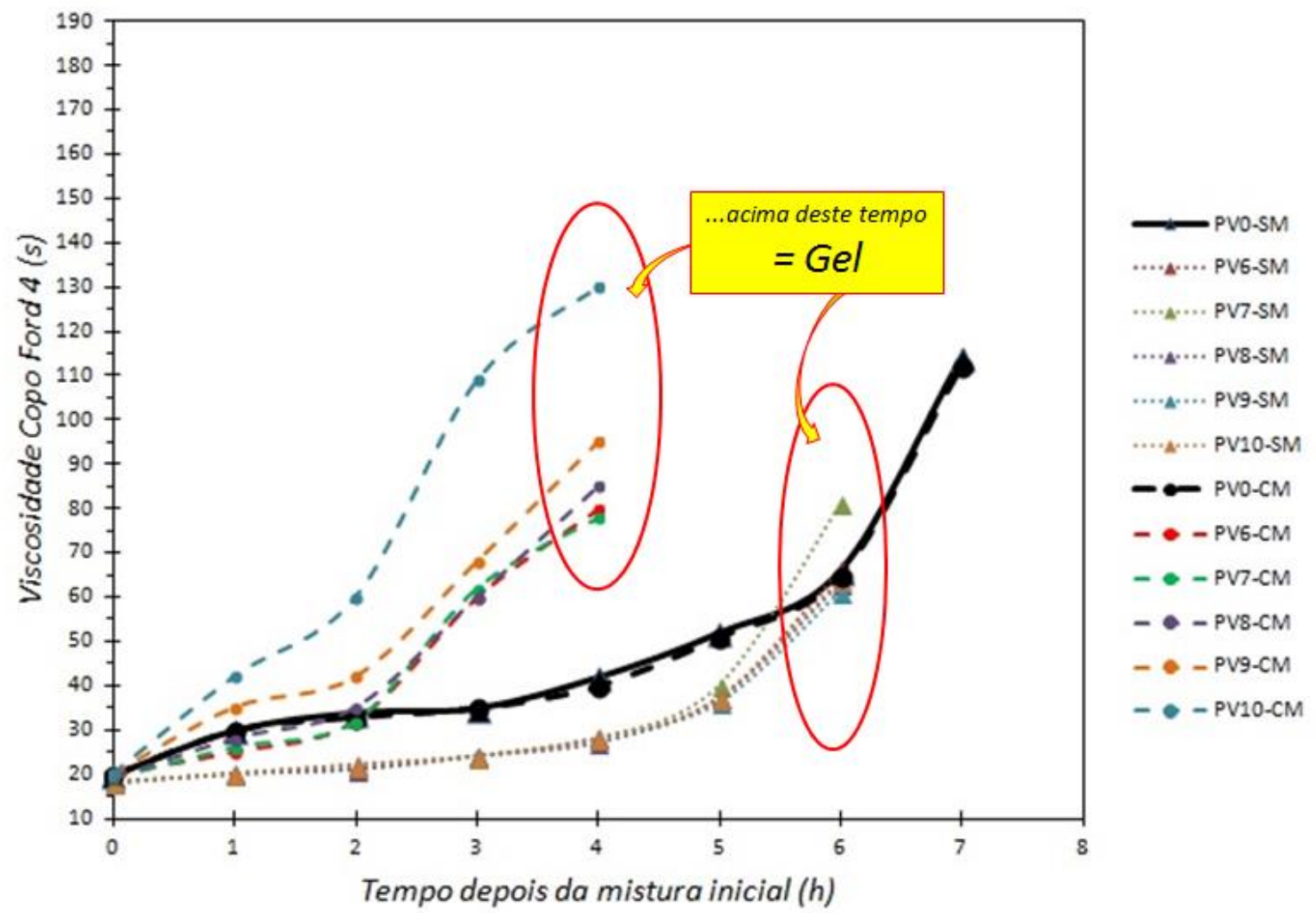

Figura 48 - Evolução da viscosidade determinada pelo método Copo Ford 4 com o tempo de reação para os sistemas contendo vermiculita processada de tamanho médio de partículas de 170,9 nm, sem calcinação a $1000^{\circ} \mathrm{C}$ (amostras PVi-SM, linha pontilhada) e após calcinação a $1000^{\circ} \mathrm{C}$ (amostra PVi$\mathrm{CM}$, linha tracejada)

Fonte: o Autor

A partir desses resultados mostrados na Figura 48, observou-se que em tempos menores ou iguais a $5 \mathrm{~h}$, a partir do momento da mistura inicial, as viscosidades das misturas contendo vermiculita de tamanho médio de 170,9 nm (não calcinada) foram menores que a viscosidade observada no verniz sem partículas de vermiculita e, não houve diferença, considerando o mesmo tempo de reação, entre vernizes com as diferentes concentrações de vermiculita. Esta observação ficou mais clara na Figura 49 onde com 6h de reação, com exceção de uma amostra onde a viscosidade foi maior (PV7-SM, com concentração de vermiculita igual a 0,25 g / $120 \mathrm{~g}$ verniz + endurecedor), os valores de viscosidade foram aproximadamente iguais à viscosidade do verniz sem vermiculita. Com $7 \mathrm{~h}$ de reação, no entanto, ocorreu um fato totalmente distinto do que foi observado no caso 
das misturas contendo vermiculita com partículas de diâmetro médio de 195,5 nm, todas as amostras contendo adição de vermiculita gelificaram, indicando a ocorrência de uma aceleração da reação entre os dois componentes da resina de alguma forma catalisada pela presença da vermiculita.

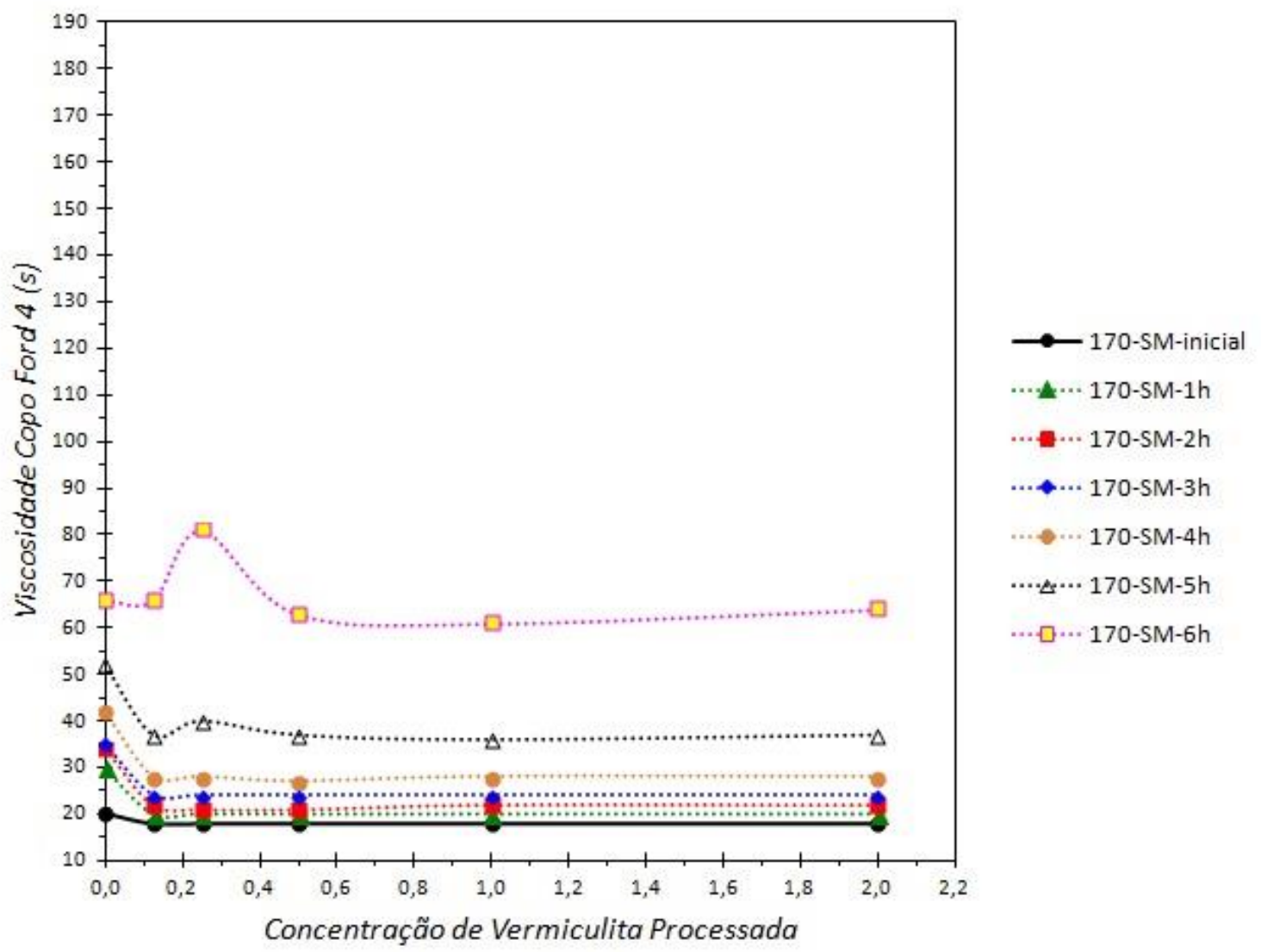

Figura 49 - Evolução da viscosidade determinada pelo método Copo Ford 4 com a concentração de vermiculita (dada em g de vermiculita / $120 \mathrm{~g}$ de (verniz + endurecedor) para sistemas contendo vermiculita processada de tamanho médio de partículas de $170,9 \mathrm{~nm}$, sem calcinação a $100^{\circ} \mathrm{C}$, para diferentes tempos de reação. Todas as amostras com $7 \mathrm{~h}$ de reação gelificaram, e não foi possível medir a viscosidade

Fonte: o Autor

O comportamento das misturas contendo a vermiculita com diâmetro médio menor $(170,9 \mathrm{~nm})$ calcinada a $1000^{\circ} \mathrm{C}$ após processamento é completamente distinto do que o observado nas três séries de misturas cujos resultados foram apresentados até aqui. A partir dos resultados mostrados na Figura 48, observou-se que as viscosidades dessas misturas foram geralmente maiores (e pode-se mesmo dizer significativamente maior a partir de 3 h de reação) do que a viscosidade do verniz sem adição de vermiculita processada. É digno de nota o fato de que todas as 
misturas contendo o material calcinado gelificaram com tempos de reação iguais ou superiores a $5 \mathrm{~h}$. além disso, no caso dessa série de misturas contendo esse material, a concentração da vermiculita calcinada adicionada teve um efeito positivo no aumento da viscosidade, como pode ser visto na Figura 50. Essas observações indicaram que a vermiculita piroexpandida, processada com diâmetro médio de $170,9 \mathrm{~nm}$ e posteriormente calcinada a $1000^{\circ} \mathrm{C}$, atuasse como um catalisador da reação entre os dois componentes do verniz uretânico estudado.

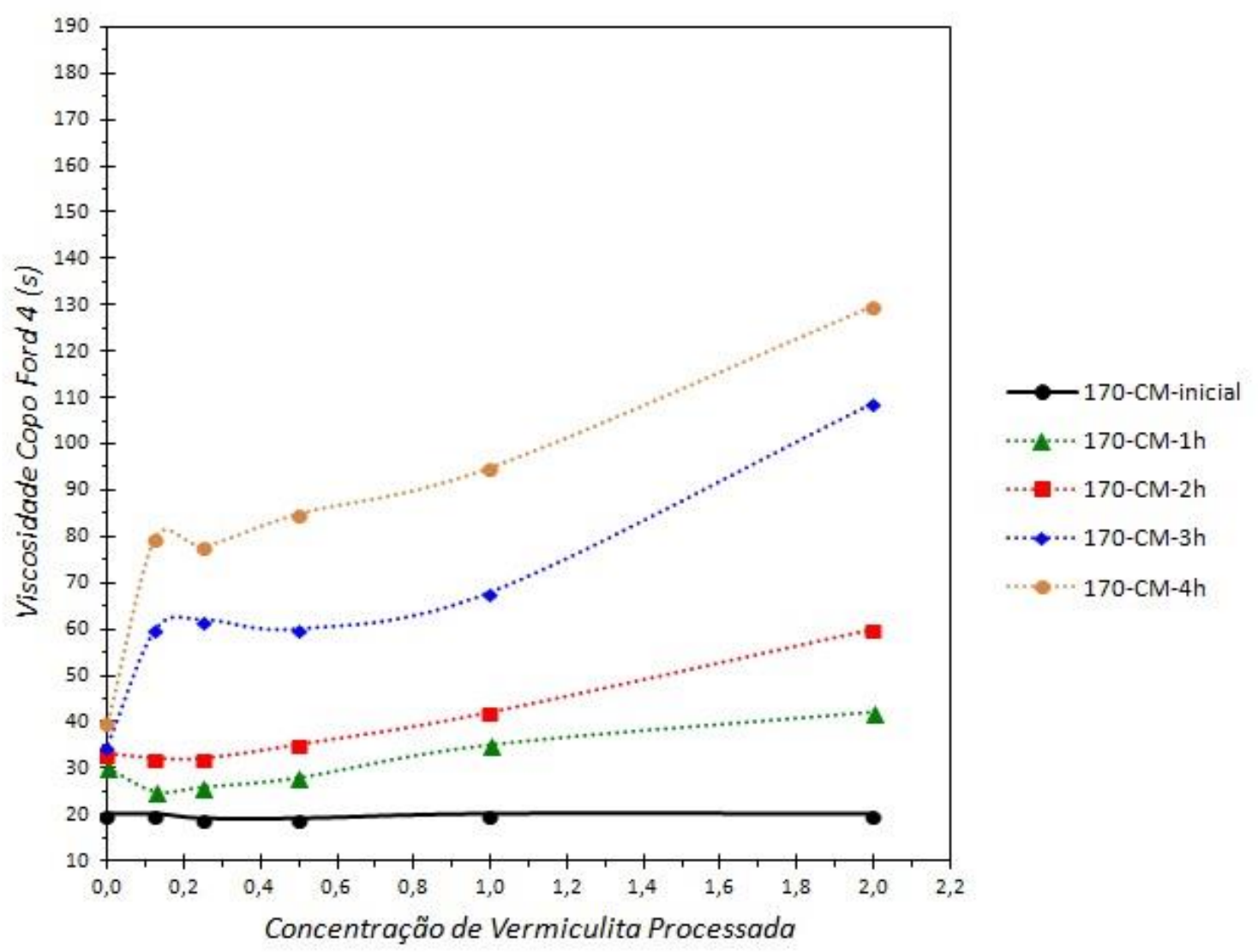

Figura 50 - Evolução da viscosidade determinada pelo método Copo Ford $4 \mathrm{com}$ a concentração de vermiculita (dada em g de vermiculita / $120 \mathrm{~g}$ de (verniz + endurecedor) para sistemas contendo vermiculita processada de tamanho médio de partículas de $170,9 \mathrm{~nm}$, com calcinação a $1000^{\circ} \mathrm{C}$, para diferentes tempos de reação. Todas as amostras com tempos de reação iguais ou superiores a $5 \mathrm{~h}$ gelificaram, e não foi possível medir a viscosidade

Fonte: o Autor

A hipótese de que a vermiculita ou de que as fases originárias da sua transformação térmica que foram identificadas nesta Tese, (um espinélio e uma fase amorfa), possam atuar como catalisadores não foi descabida. Purceno e 
colaboradores (PURCENO et al., 2012) estudaram o uso de vermiculita piroexpandida moída como catalisador, onde o ferro estrutural presente na folha octaédrica da vermiculita atuaria como catalisador de uma reação de oxidação. A reação entre os dois componentes do verniz uretânico, tratada nesta Tese, não foi uma reação de oxidação, mas o trabalho citado mostrou que é possível que o ferro, seja fazendo parte da folha octaédrica da vermiculita expandida e não totalmente desidroxilada, seja fazendo parte da estrutura da enstatita ou da fase amorfa formadas após a calcinação a $1000^{\circ} \mathrm{C}$, possa ser acessível (exposto nas bordas das partículas cristalinas ou amorfas devido ao processo de moagem), estando disponível, portanto, para uma atividade catalítica.

A literatura diz que o $\mathrm{Fe}^{2+}$ é um potencial catalisador para sistemas uretânicos (SZYCHER, 2013). Apesar do fato de que os processos tanto da piroexpansão (que produziu o material de partida que foi processado nesta Tese), quanto da calcinação posterior a $1000^{\circ} \mathrm{C}$ em atmosfera de ar (portanto, em condições oxidantes, ou seja, que privilegiaram a oxidação do ferro presente a $\mathrm{Fe}^{3+}$ ) à qual o material processado foi submetido, o trabalho de Purceno e colaboradores mencionado evidenciou a presença de $\mathrm{Fe}^{2+}$ em vermiculita piroexpandida e, nesta Tese, identificamos por DRX uma enstatita no material calcinado a $1000^{\circ} \mathrm{C}$. Como já mencionado anteriormente, a enstatita é um mineral cuja composição é $\mathrm{Mg}_{2} \mathrm{Si}_{2} \mathrm{O}_{6}$, mas pode existir toda uma gama de substituições de $\mathrm{Mg}^{2+}$ por $\mathrm{Fe}^{2+}$ na estrutura desse silicato, desde o limite magnesiano que é a enstatita, até o limite ferroso que é a ferrosilita $\mathrm{Fe}^{2+}{ }_{2} \mathrm{Si}_{2} \mathrm{O}_{6}$. Dada a composição da vermiculita de partida, pode-se supor que possa existir a presença de $\mathrm{Fe}^{2+}$ estabilizado na estrutura de uma composto intermediário entre a enstatita e a ferrossilita, estando acessível em alguma superfície dessa fase cristalina (ou mesmo fazendo parte da fase amorfa cuja presença foi identificada por $\mathrm{DRX})$. Esse $\mathrm{Fe}^{2+}$ poderia atuar como catalisador e acelerar a velocidade da reação entre os dois componentes do verniz, levando a uma aumento pronunciado da viscosidade e mesmo à gelificação.

Um efeito desse tipo seria mais pronunciado pela existência de uma maior superfície específica exposta no meio; sendo, portanto, lógico esperar esse comportamento no material mais fino, neste caso, a vermiculita processada de menor tamanho médio de partícula $(170,9 \mathrm{~nm})$. 


\section{6 - Comportamento da vermiculita processada como barreira ao transporte de massa em filmes uretânicos}

Os fenômenos eletroquímicos, nos revestimentos orgânicos, podem ser estudados para compreensão de diversos comportamentos (CAO-PAZ et al., 2010). Fenômenos, como corrosão em aço carbono fosfatizados, também podem ser estudados (GUENBOUR et tal, 1999), bem como fenômenos ligados à porosidade dos revestimentos (GREGG e Sing, 1982). Também podem ser utilizadas técnicas de impedância para avaliar os fenômenos de corrosão (PEBERE et al., 1989).

Na Figura 51, são mostrados os diagramas de impedância para solução de $\mathrm{NaCl} 0,1 \mathrm{M}$ e os corpos de prova:

- $\mathrm{MB}$ (metal base) : liga de aço carbono 1020 revestida somente com fosfato de zinco

- PU : liga de aço carbono 1020 revestida com fosfato de zinco; recoberta com filme de dispersão uretânica e

- PU/VE : ligas de aço carbono 1020 revestidas com fosfato de zinco; recobertas com filmes formados pela mistura de dispersão uretânica com vermiculita processada.

Observando os formatos típicos das curvas de impedância eletroquímica em estudos de corrosão, as curvas $Z^{\prime}$ de impedância mostrados na Figura 51, podem ser interpretadas levando em conta o fenômeno de transporte de fluído. Por este raciocínio, o melhor nível de barreira ao fluxo foi alcançado pelo sistema contendo $12 \%$ de vermiculita, uma vez que o valor final de $Z^{\prime}$ para o sistema com vermiculita chegou próximo de 3500 ohm.cm². Nas demais concentrações, ambos os materiais apresentaram níveis similares de proteção ao transporte da solução iônica de $\mathrm{NaCl}$.

Para explicar essa observação recorreu-se a um modelo; a existência de uma barreira difusional formada pelas placas de vermiculita presentes no interior do filme. Para colaborar com esse modelo observou-se no diagrama de Nyquist, que o comportamento do filme formado somente pela resina pura apresentou característica de um filme permeável e, as adições de partículas de vermiculita alterou o comportamento deste filme original. 


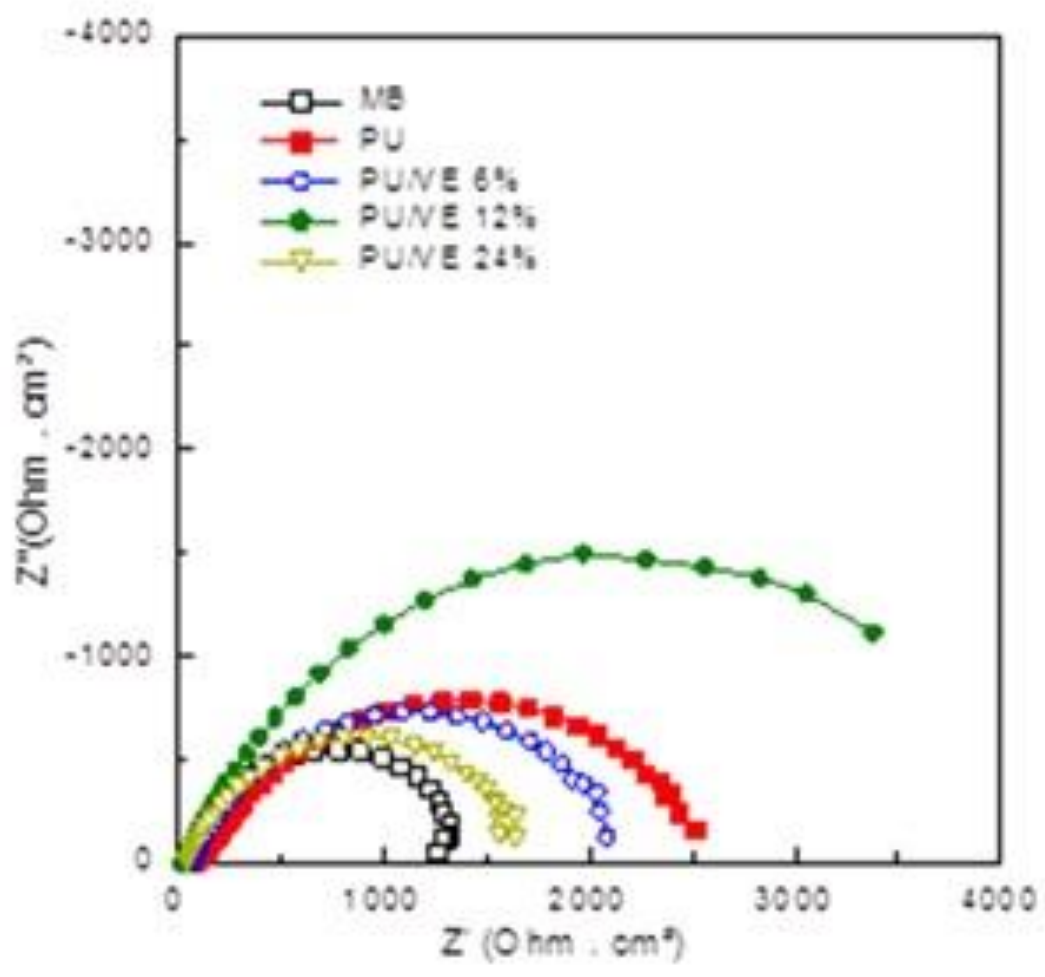

Figura 51 - Diagrama de impedância de Nyquist, solução de $\mathrm{NaCl} 0,1 \mathrm{M}$, para liga de aço carbono 1020 Metal Base (MB) e liga aço carbono 1020 tratado com fosfato de zinco revestidos com dispersão uretânica contendo vermiculita processada (VE)

Fonte: LPE - PMT - EPUSP, imagens obtidas para esta Tese e para outros trabalhos do PMT EPUSP empregando vermiculitas

Concentrações inferiores a 12 \% de vemiculita levaram a uma "população" de partículas lamelares insuficientes para bloquear, de forma eficiente, o transporte de massa do fluido através do filme formado pela dispersão uretânica e pelas partículas de vermiculita. Para a concentração superior a $12 \%$, pode ter ocorrido um efeito conjugado. Primeiro; a existência de elevada absorção de resina; motivado pelo excesso de área superficial das partículas de vermiculita, "faltando" resina uretânica para permitir a livre movimentação das partículas de vermiculita, dificultando o rearranjo das partículas lamelares do mineral no interior do filme. Segundo; a existência de um desequilíbrio volumétrico entre os volumes relativos da resina nãovolátil e o volume das partículas de vermiculita, facilitando a criação de canais de fluxo no interior do filme; fato provocado pela desorientação espacial das placas de vermiculita. 
Pode-se portanto, concluir que dentre as concentrações estudadas, existe uma que representa a melhor relação entre as quantidades mássicas envolvendo partículas de vermiculita (12\%), e resina uretânica não volátil; para reduzir o transporte de fluído no interior do filme aplicado. 


\section{CONCLUSÕES}

Para atender aos objetivos propostos nesta Tese; que envolveu a investigação das propriedades da vermiculita como carga ativa em verniz uretânico, algumas informações importantes, foram obtidas a partir da analise dos resultados experimentais. Estes dados reforçaram que as partículas de vermiculita interagiram com o meio onde estas foram adicionadas como era proposto e esperado obtendo novas propriedades para estes sistemas.

\section{Obtenção de partículas de vermiculita piroexpandida (vermiculita processada).}

- Obtenção das partículas de vermiculita: O processamento utilizado para a transformação da vermiculita piroexpandida em partículas com dimensões reduzidas mostraram-se efetivos e viáveis.

- Meios para moagem: As moagens em meio aquoso e, em meio de solvente orgânico, podem ser utilizados com diferentes tempos de processamento para obtenção de dispersões estáveis com diferentes tamanhos de partículas de vermiculita piroexpandida.

- Partículas na forma de pó: A obtenção de partículas de vermiculita processada na forma de pó, foram facilmente obtidas através da extração dos solventes por meio aquecimento em estufa e, os aglomerados dos pós secos, foram de fácil desagregação.

\section{Compatibilidade das partículas de vermiculita nos meios estudados}

- Compatibilidade: A incorporação das dispersões das partículas de vermiculita piroexpandida, em sistemas resinosos à base de água e à base de solventes orgânicos, foram plenamente viáveis. Acreditamos que houve ação de diluição dos solventes sobre as resinas presentes nos sistemas estudados. 


\section{Estabilidade das dispersões moídas}

- Estabilidade: Foi observado que decorridos 6 meses após a obtenção das dispersões das partículas de vermiculita (meio aquoso e meio de solvente orgânico) estas ainda se encontravam próprias para utilização.

O armazenamento ocorreu em frascos de polietileno, hermeticamente vedados e mantidos à temperatura ambiente média de $25^{\circ} \mathrm{C}$.

\section{Desenvolvimento de cor gerado pelas partículas de vermiculita}

- Cor das partículas obtidas: Foi verificado que as partículas de vermiculita possuem cor e, estas partículas foram capazes de promover cor aos sistemas uretânicos estudados na Tese

- Cor das combinações [resina + vermiculita processada]: observou-se o aparecimento de cor com tonalidade vermelha-amarelada. Cor esta muito diferente da cor presente nas partículas na forma de pó. Foi mostrado que a intensidade da cor foi dependente da granulometria e da concentração das partículas de vermiculita processada.

- Luminosidade das combinações [resina uretânica + vermiculita processada]: Observou-se que a vermiculita processada apresentou comportamentos distintos em relação à luminosidade (claro e escuro). Na sua forma de pó, seco apresentou características claras e, combinada com resina apresentou um redução na luminosidade (menores valores de $L$ ); tornando-se mais escura; cor próxima a um marrom muito escuro.

- Cor e luminosidade em vernizes uretânicos aplicados sobre a tinta prata: Foi observado que houve surgimento de cor nos vernizes contendo adições de partículas de vermiculita processada. Houve alterações nos valores do eixo $a^{*}$, tonalidade vermelha, e alterações nos valores do eixo $b^{*}$, tonalidade amarela. Quanto à luminosidade, observou-se que, quanto maior a quantidade de partículas de vermiculita processada adicionada ao verniz, maior a variação nos valores de $L^{*}$ (e de $\Delta L^{*}$ ) escurecendo a "luminosidade" da película seca do verniz. Observou-se também que, 
partículas de vermiculita processada com menores tamanhos são mais efetivas para o escurecimento do verniz (luminosidade). Quanto aos ângulos de leitura, da cor e da luminosidade, a $45^{\circ}$ e $75^{\circ}$; observou-se que as variações na tonalidade foram despreziveis e que as maiores variações ocorreram na luminosidade para as leituras no ângulo de $75^{\circ}$.

- Os resultados comprovaram que a presença de partículas de vermiculita processada promoveram alterações de cor no verniz.

\section{Desenvolvimento de dureza superficial em filmes uretânicos}

- Dureza : Foi observado aumento da dureza superficial dos filmes com a adição de vermiculita processada. Esse aumento, aparentemente, não depende do tamanho médio de partícula.

\section{Velocidade de reação em sistemas uretânicos (efeito catalítico)}

- Efeito catalítico da vermiculita processada: Os resultados dos ensaios mostraram que houve uma aceleração na reação entre os grupos $-\mathrm{OH}$, presentes da resina, e os grupos - NCO do endurecedor. Isto justifica-se pois, houve aumento dos valores da viscosidade da mistura líquida com o passar do tempo e, ocorreram também, elevações na dureza superficial nos filmes dos vernizes. Podemos atribuir estes efeitos a uma ação catalítica; pensamos que à presença de elementos metálicos (em especial o $\mathrm{Fe}^{2+}$ ), presente na composição da vermiculita processada, tenha sido o responsável por esta ação catalítica.

\section{Propriedade de barreira em filmes uretânicos}

- Efeito de Barreira: Foi identificado, nesta Tese, que existiu uma relação mássica ideal, entre resina e partículas de vermiculita, que foi capaz promover impedimento de fluxo difusional no filme de verniz aplicado sobre aço carbono 1020. Pensamos que este efeito poderia ser atribuído ao 
arranjo lamelar das partículas de vermiculita presente no interior do filme do verniz.

\section{Conclusão geral da Tese}

O trabalho experimental, realizado no âmbito desta Tese, permitiu mostrar que o material particulado, obtido por moagem da vermiculita piroexpandida, poderá ser utilizado como possível matéria-prima em vernizes de matriz uretânica. Este material particulado, foi capaz de gerar propriedades específicas de dureza, cor, ação catalítica e barreira difusional nos vernizes uretânicos estudados. 


\section{SUGESTÕES PARA FUTUROS TRABALHOS}

Tendo disponibilidade para obtenção da vermiculita piroexpandida na forma de partículas, como descrito nesta Tese, apresento algumas sugestões para possíveis trabalhos na Tabela 24 a seguir.

Tabela 24 - Sugestões para futuros trabalhos

\begin{tabular}{|c|c|}
\hline \multicolumn{2}{|c|}{ SUGESTÕES PARA FUTUROS TRABALHOS } \\
\hline $\begin{array}{c}\text { UTILIZAR AS PARTÍCULAS DE } \\
\text { VERMICULITA PARA }\end{array}$ & $\begin{array}{c}\text { SUGESTÕES PARA ABORDAGENS NO } \\
\text { TRABALHO }\end{array}$ \\
\hline Adição como carga em Polímeros termofixos & $\begin{array}{c}\text { Pode-se trabalhar com sistemas de } 2 \\
\text { componentes: poliuretanos, epóxis entre outros } \\
\text { ou, em sistemas auto reticuláveis }\end{array}$ \\
\hline $\begin{array}{c}\text { Adição como cargas em Polímeros } \\
\text { termoplásticos }\end{array}$ & $\begin{array}{l}\text { Neste caso, existe uma quantidade enorme de } \\
\text { opções de polímeros termoplásticos para livre } \\
\text { escolha de trabalho. Por exemplo um TPU }\end{array}$ \\
\hline $\begin{array}{l}\text { Adição em sistemas de filmes orgânicos para } \\
\text { estudo de proteção à corrosão }\end{array}$ & $\begin{array}{l}\text { Pode-se escolher quaisquer tintas ou vernizes, } \\
\text { preferencialmente sistemas epóxi de } 2 \\
\text { componentes como por exemplo, tintas epóxi } \\
\text { amino curadas ou poliamidas entre outras }\end{array}$ \\
\hline Adição em polímeros para embalagens & $\begin{array}{l}\text { Escolher os polímeros do segmento de } \\
\text { embalagem e efetuar as adições }\end{array}$ \\
\hline Utilização em vernizes para madeira ou afins & $\begin{array}{c}\text { Escolher uma formulação tradicional e, efetuar } \\
\text { as adições realizando os ensaios de resistência } \\
\text { da especificação do material }\end{array}$ \\
\hline Pesquisas na área de materiais & $\begin{array}{l}\text { Possíveis estudos na área de isolamento } \\
\text { acústico, térmico ou mesmo a extração dos } \\
\text { metais presentes na estrutura do mineral } \\
\text { vermiculita para aceleração de efeitos catalíticos } \\
\text { ou para aplicação em outros campos ligados à } \\
\text { engenharia de materiais }\end{array}$ \\
\hline $\begin{array}{c}\text { Estudo do poder de tingimento, coberturas secas } \\
\text { e úmidas, resistência à luz e ao intemperismo } \\
\text { natural }\end{array}$ & $\begin{array}{c}\text { Escolher uma formulação de tinta e efetuar } \\
\text { adições até o nível de cobertura seca ou úmida } \\
\text { desejado, ensaiar cortes de tingimento efetuando } \\
\text { leituras em espectrofotômetros e nos demais } \\
\text { equipamentos }\end{array}$ \\
\hline
\end{tabular}




\section{REFERÊNCIAS.}

ADAMSONS, K. Chemical surface characterization and depth profiling of automotive coating systems. Prog. Polym. Sci. 25, 1363-1409 (2000).

AULIN, C.; SALAZAR-ALVAREZ, G.; LINDSTRÖM, T. High strength, flexible and transparent nanofibrillated cellulose-nanoclay biohybrid films with tunable oxygen and water vapor permeability. Nanoscale 4, 6622. 2012.

BADREDDINE, R.; VANDORMAEL, D.; FRANSOLET, A.-M.; LONG, G.J.; STONE, W.E.E.; GRANDJEAN, F. A comparative X-ray diffraction, Mössbauer and NMR spectroscopic study of the vermiculites from Béni Bousera, Morocco and Palabora, Republic of South Africa. Clay Minerals 37, 367-376, 2002.

BARABASZOVÁ, K.Č.; VALÁŠKOVÁ, M. Characterization of vermiculite particles after different milling techniques. Powder Technology 239, 277-283. 2013.

BRINDLEY, G.W.; ZALBA, P.E.; BETHKE, C.M. Hydrobiotite, a regular 1:1 interstratification of biotite and vermiculite layers. American Mineralogist 68, 420-425, 1983.

CALLISTER JUNIOR, W.D. Materials Science and Engineering - An Introduction. Wiley. New York. $7^{\text {th }}$ Ed. 2007

CAO-PAZ , A.; COVELO, A.; FARINA, J.; NÓVOA, X.R.; PÉREZ, C.; RODRÍGUEZPARDO, L. Ingress of water into organic coatings : Real-time monitoring of the capacitance and increase in mass. Progress in Organic Coatings 69 (2), 150157. 2010.

CASERI, W.R. Nanocomposites of polymers and inorganic particles: preparation, structure and properties. Materials Science and Technology 22, 807-817. 2006.

CHATTOPADHYAY, D.K.; RAJU, K.V.S.N. Structural engineering of polyurethane coatings for high performance applications. Progress in Polymer Science 32, 352-418. 2007.

COLLONG, W.; GÖBEL, A.; KLEUSER, B.; LENHARD, W.; SONNTAG, M. 2K waterborne clearcoat-a competition between crosslinking and side reactions. Progress in Organic Coatings 45, 205-209. 2002.

DAOFU, L.; XUSHENG, D; YUEZ. M. Facile synthesis of exfoliated polyaniline / vermiculite nanocomposites. Elsevier.v 60, p. 1847-1850, 2006.

DYAR, D.; GUNTER, M.E.; TASA, D. Mineralogy and Optical Mineralogy. Mineralogical Society of America. pag. 212. 2008.

FAZENDA, J.M.R.; CRUZ, A.R.P; ROCHA, A.N.; GNECCO, C. Tintas: Ciência e Tecnologia, ABRAFATI, São Paulo, 6, 232-244. 2009.

GEURINK, P.J.A.; SCHERER, T.; BUTER, R.; STEENBERGEN, A.; HENDERIKS, $H$., 2006. A complete new design for waterborne 2-pack PUR coatings with 
robust application properties. Progress in Organic Coatings 55, 119-127. 2006.

GIBSON, S.H.M.; ROWE, R.C.; WHITE, E.F.T. The mechanical properties of pigmented tablet coating formulations and their resistance to cracking. II. Dynamic mechanical measurement. International Journal of Pharmaceutics 50(2), 163-173. 1989.

GREGG, S.J.; SING, K.S.W. Adsorption, Surface Area and Porosity. 2ª ed. Academic Presss Inc., London, 1982.

GUENBOUR, A.; BENBACHIR,A.; KACEMI, A. Evaluation of the corrosion performance of zinc-phosphate-painted carbon steel. Surface and Coatings Technology 113 (1-2), 36-43. 1999.

HINDMAN, J.R. Vermiculite, in Industrial Minerals and Rocks. 5 ${ }^{\mathrm{a}}$ Ed. Society for Mining, Metallurgy and Exploration. Londres. P. 1103-1111. 1992.

IMA - International MIneralogical Association. IMA-CNMNS List of Mineral Names. Updated 2017. <http://nrmima.nrm.se//imalist.htm>, consultado em julho de 2017.

ISMAIL,T.N.M.T.; PALAM, K.D.P.; BAKAR, Z.B.A.; SOI, H.S.; KIAN, Y.S.;HASSAN, H.A.; SCHIFFMAN, C.; SENDIJAREVIC, A.; SENDIJAREVIC, V.; SENDIJAREVIC, I. Urethane-forming reaction kinetics and catalysis of model palm olein polyols: Quantified impact of primary and secondary hydroxyls. J. Appliedm Polymer Science 133 (2), 42955. 2016.

JUSTO, A.; MAQUEDA, C.; PÉREZ-RODRíGUEZ, J.L.; LAGALY, G. An unusually expandable low-charge vermiculite. Clay Minerals 22, 319-327, 1987.

KLEIN, C.; DUTROW, B. Manual de Ciência dos Minerais. 23aㅗ Ed. Bookman. Porto Alegre. 2008. . Caps.18 e 19..

KLEIN, C.; HURLBUT Jr.;C. Manual of Mineralogy.21 ${ }^{\text {st }}$ Ed. Wiley. Nova York. 1977. .p.515.

KOTAL, M.; BHOWMICK, A.K. 2015. Polymer nanocomposites from modified clays: Recent advances and challenges. Progress in Polymer Science 51, 127-187. 2015.

KŘÍSTKOVÁ, M.; WEISS, Z.; FILIP, P. Hydration properties of vermiculite in phenolic resin friction composites. Applied Clay Science 25, 229-236. 2004.

LAN, T.; KAVIRATNA, P.D.; PINNAVAIA, T.J. Mechanism of Clay Tactoid Exfoliation in Epoxy-Clay Nanocomposites. Chemistry of Materials 7, 2144-2150. 1995.

LIMA, T. M.; Medeiros, K. A.. Departamento Nacional de Produção Mineral-DNPM. Sumário mineral - 2015. Brasília: DNPM, 2016.

MME - Ministério das Minas e Energia. Governo Federal. $<$ http://www.dnpm.gov.br/dnpm/sumarios/sumario-mineral-2015>, consultado em julho de 2017. 
MUSIĆ, S.; FILIPOVIĆ-VINCEKOVIĆ, N.; SEKOVANIĆ, L. Precipitation of amorphous $\mathrm{SiO}_{2}$ particles and their properties. Brazilian Journal of Chemical Engineering 28 (1), 89-94, 2011.

PATRO, T.U.; HARIKRISHNAN, G.; MISRA, A.; KHAKHAR, D.V. Formation and characterization of polyurethane-vermiculite clay nanocomposite foams. Polymer Engineering \& Science 48, 1778-1784. 2008.

PEBERE,N.; PICAUD, TH.; DUPRAT, M.; DABOSI, F. Evaluation of corrosion performance of coated steel by impedance technique. Corrosion Technique 29(9), 1073-1086. 1989.

PURCENO, A.D.; TEIXEIRA, A.P.C.; SOUZA, A.B.; ARDISSON, J.D.; MESQUITA, J.P.; LAGO, R.M. Ground vermiculite as catalyst for the Fenton reaction. Applied Clay Science 69, 87-92. 2012.

QIAN, Y.; LINDSAY, C.I., MACOSKO, C.; STEIN, A., 2011. Synthesis and Properties of Vermiculite-Reinforced Polyurethane Nanocomposites. ACS Applied Materials \& Interfaces 3, 3709-3717. doi:10.1021/am2008954

RAZIN, A.A., YARI, H.; RAMEZANZADEH, B. Stone-chipping and adhesion deterioration of automotive coating systems caused by outdoor weathering of underneath layers. Journal of Industrial and Engineering Chemistry 31, 291300. 2015.

ROCHA, M.N.; FUJIMOTO, T.G.; AZEVEDO, R.S.; MURAMATSU, M. O azul do céu e o vermelho do pôr do sol. Revista Brasileira de Ensino de Física 32, (3), 3501.2010.

SILVA, H.H.A.B. Caracterização Mineralógica e Filiação da Vermiculita da Mina Cerrado III - Sanclerlândia - GO. Dissertação de Mestrado. UNB. 2006.

SOUSA SANTOS, P. Ciência e Tecnologia de Argilas. 2 ${ }^{\underline{a}}$ Ed. Edgard Blücher. São Paulo. p.855-865. 1992.

SZYCHER, M. Szycher's Handbook of Polyurethane. $2^{\text {nd }}$ Ed. CRC Press/Taylor \& Francis. pgs 143 e 333. 2013.

TJONG, S.C., MENG, Y.Z., HAY, A.S. Novel Preparation and Properties of Polypropylene-Vermiculite Nanocomposites. Chemistry of Materials 14, 44-51. 2002.

TJONG, S.C.; MENG, Y.Z.; XU, Y. Preparation and properties of polyamide 6/polypropylene-vermiculite nanocomposite/polyamide 6 alloys. Journal of Applied Polymer Science 86, 2330-2337. 2002.

UGARTE, J.F.O.; SAMPAIO, J.A.; FRANÇA, S.C.A. Vermiculita, in LUZ, A.B.; LINS, F.A.F (Eds.) Rochas e Minerais Industriais. CETEM-MCT. Cap. 32. 2005.

WEBMINERAL. Vermiculite Mineral Data. $<$ http://webmineral.com/data/Vermiculite.shtml\#.WW49ioTysdU>, consultado em julho de 2017. 